\title{
APLICAÇÃO DE CONCEITOS DA QUALIDADE EM OPERAÇÕES MECANIZADAS NA PRODUÇÃO DE MILHO (Zea mays L.) PARA SILAGEM
}

\section{RICARDO ALVES THOMAZ FERNANDES}

Engenheiro Agrônomo

Orientador: Prof. Dr. MARCOS MILAN

Dissertação apresentada à Escola Superior de Agricultura "Luiz de Queiroz", Universidade de São Paulo, para obtenção do título de Mestre em Agronomia, Área de Concentração: Máquinas Agrícolas.

P I R A C I C A B A

Estado de São Paulo - Brasil

Dezembro - 2000 
Dados Internacionais de Catalogação na Publicação (CIP) DIVISĀO DE BIBLIOTECA E DOCUMENTAÇĀO - Campus "Luiz de OueirOz"/USP

Fernandes, Ricardo Alves Thomaz Aplicação de conceitos da qualidade em operações mecanizadas na produção de milho ( $Z e a$ mays L.) para silagem / Ricardo Alves Thomaz Femandes. - - Piracicaba, 2000.

81 p. : il.

Dissertação (mestrado) - - Escola Superior de Agricultura Luiz de Queiroz, 2001. Bibliografia.

1. Controle de qualidade 2. Mecanização agricola 3. Milho 4. Silagem 5. Sistema de produção I. Título

CDD 633.15

Termitida a copia total ou parcial deste documento, desde que citada a fonte - 0 autor 
A meus avós Laurindo (in memorian) e Auzinda, Melchiades e Leonor, meus pais Virgilio e Gislaine, e meus irmãos Vinicius e Fernanda, por me ensinarem o valor de meu sobrenome, o respeito e o significado da palavra FAMÍLIA, dedico. 


\section{AGRADECIMENTOS}

\section{A Deus;}

À minha família por todo o carinho e confiança depositados em mim, nestes 25 anos de vida;

Ao meu orientador Prof. Dr. Marcos Milan, pelo conhecimento dividido e pela paciência;

Ao Pesquisador Científico, Afonso Peche Filho (CMAA-IAC), pelas longas conversas sobre qualidade;

Ao Prof. Dr. Luiz Gustavo Nussio (ESALQ/USP), pela receptividade, pelas idéias e soluções;

Aos docentes do Departamento de Engenharia Rural da Escola Superior de Agricultura "Luiz de Queiroz", USP, pela formação profissional;

Aos funcionários do Departamento de Engenharia Rural e Produção Animal, da ESALQ/USP pela força e presteza em momentos decisivos;

Aos amigos e irmãos da República KAI $\pi$ RA, pelas alegrias e tristezas divididas;

Aos amigos e irmãos da F-97, nos quais tenho mel consolo, esperanças e amizade incondicionais;

À querida Enga Agr $^{a}$ Luciana Yuri Sato, a qual nunca soube dizer não aos meus incansáveis pedidos de ajuda, e que por muitas vezes foi meu combustível nessa jornada. 


\section{SUMÁRIO}

Página

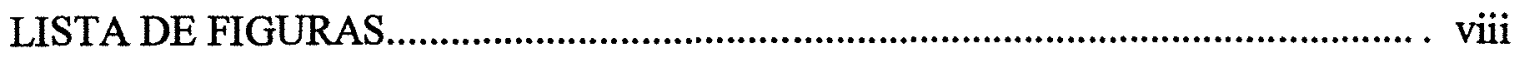

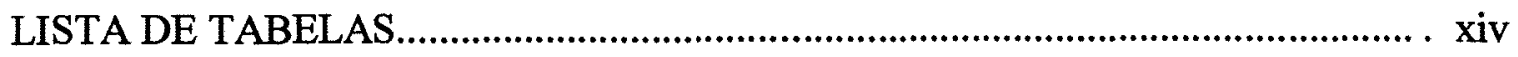

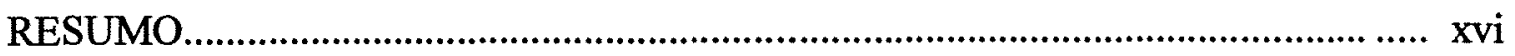

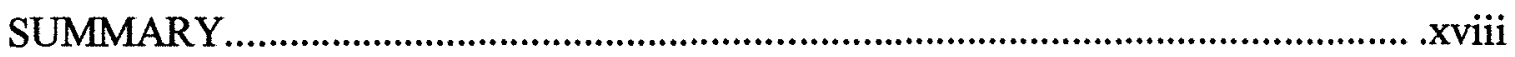

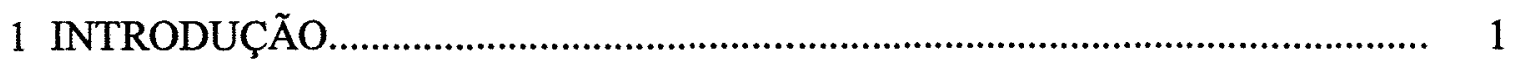

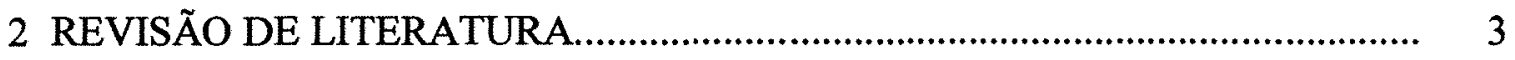

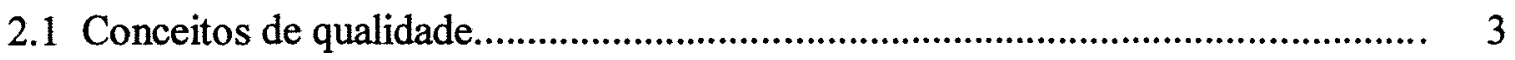

2.1.1 Qualidade: definição.................................................................................. 3

2.1.2 Rotina, melhoria e produtividade............................................................ 3

2.1.3 O controle estatístico de processos (CEP) .................................................... 4

2.1.4 Alguns conceitos do controle estatístico de processos (CEP) ........................ 6

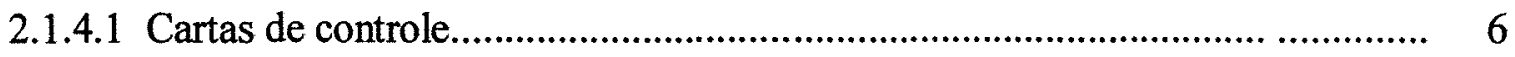

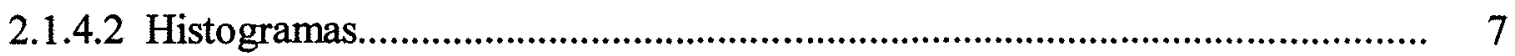

2.1.4.3 Diagramas de dispersão..................................................................... 8

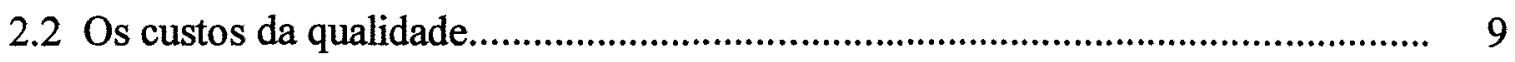

2.3 A qualidade aplicada na agropecuária......................................................... 10

2.3.1 A qualidade por toda a cadeia agroalimentar............................................. 10

2.3.2 Controle de qualidade em operações agrícolas.............................................. 12

2.4 Fatores que influenciam a qualidade e produção de silagem.............................. 14

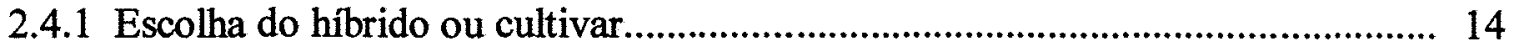

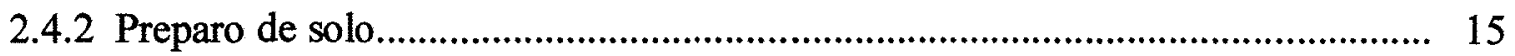

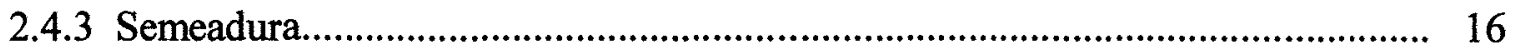

2.4.4 Composição e desenvolvimento da planta...................................................... 18

2.4.5 Ponto de colheita................................................................................ 22

2.4.6 Corte e tamanho da partícula da planta de milho............................................ 23

3 MATERIAL E MÉTODOS............................................................................. 25

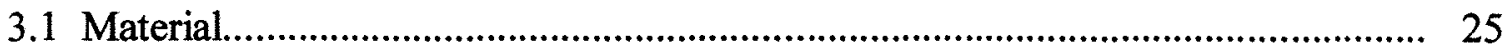




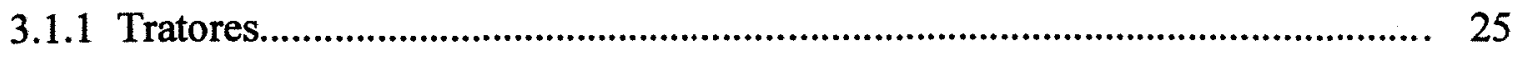

3.1.2 Máquinas e implementos............................................................................... 25

3.1.3 Análise das características de preparo do solo................................................. 26

3.1.3.1 Profundidade de preparo .......................................................................... 26

3.1.3.2 Tamanho de torrão .............................................................................. 27

3.1.4 Análise das características da cultura............................................................. 28

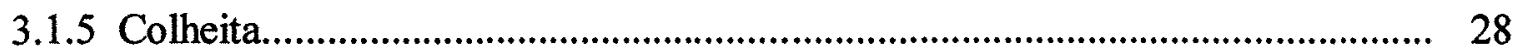

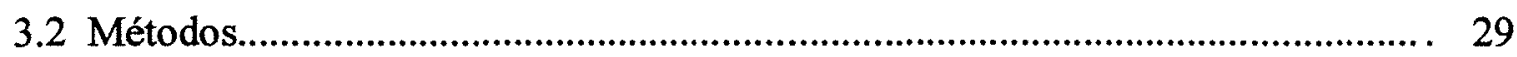

3.2.1 Instalação das parcelas.................................................................................... . 29

3.2.2 Procedimento operacional e análise dos valores............................................. 30

3.2.3 Avaliação dos parâmetros.......................................................................... 31

3.2.3.1 Profundidade de trabalho........................................................................... 31

3.2.3.2 Diâmetro de torrão..................................................................................... 32

3.2.3.3 Espaçamento entre plantas.................................................................. 33

3.2.3.4 Altura de plantas......................................................................................... 34

3.2.3.5 Colheita................................................................................................ 34

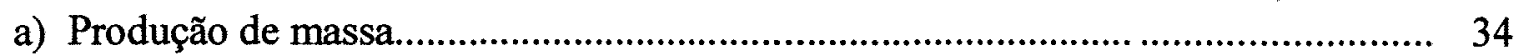

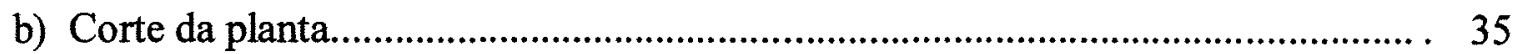

c) Avaliação das partículas de forragem.................................................................. 35

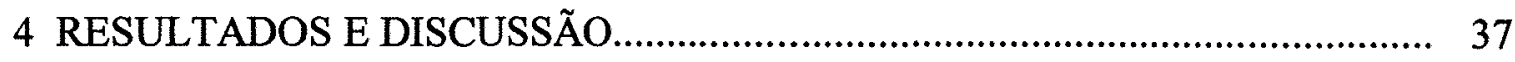

4.1 Operação de escarificação...................................................................................... 37

4.1.1 Linha de preparo do solo.............................................................................. 41

4.1.2 Entrelinha de preparo do solo....................................................................... 44

4.2 Operação de gradagem........................................................................................ 48

4.3 Operação de semeadura................................................................................ 51

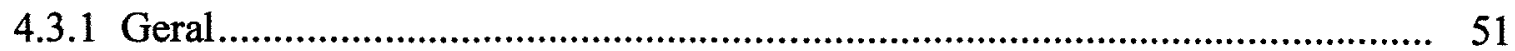

4.3.2 Avaliação das unidades ........................................................................... 53

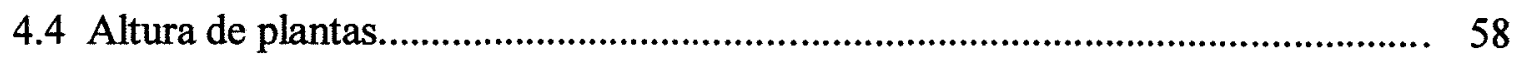

4.5 Operação de colheita......................................................................................... 60

4.5.1 Produção de massa................................................................................................ 60 


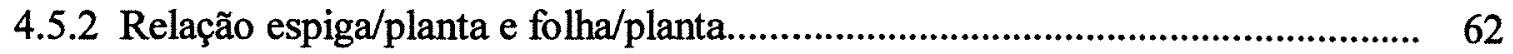

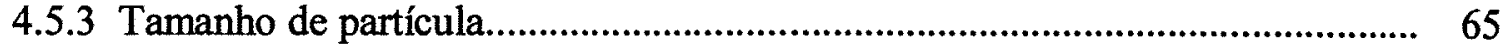

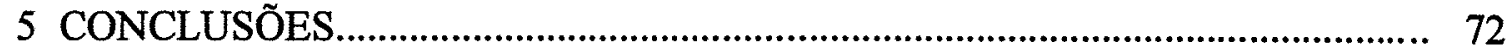

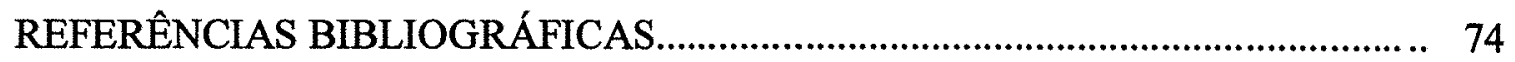




\section{LISTA DE FIGURAS}

Página

1 Esquema de uma carta de controle e suas zonas espaciais

2 Parâmetros da qualidade da cadeia bovina, conforme os segmentos da cadeia produtiva

3 Modelo do penetrômetro hidráulico utilizado no experimento

4 Esquema do dispositivo criado para a medição do tamanho dos torrões nas áreas analisadas

5 Modelo da malha aplicada aos talhões analisados no experimento

6 As operações mecanizadas avaliadas, seus indicadores e limites de especificação

7 Histograma de distribuição da profundidade de escarificação, na área A1.

8 Histograma de distribuição da profundidade de escarificação, na área A2

9 Carta de controle com médias, para a operação de escarificação, na área A1

10 Carta de controle com médias, para a operação de escarificação, na área A2. 
11 Carta de controle com amplitudes, para a operação de escarificação, na área $\mathrm{A} 1$

12 Carta de controle com amplitudes, para a operação de escarificação, na área $\mathrm{A} 2$.

13 Carta de controle com médias, para a operação de escarificação na linha de preparo, na área $\mathrm{A} 1$

14 Carta de controle com médias, para a operação de escarificação na linha de preparo, na área A2

15 Carta de controle com amplitudes, para a operação de escarificação na linha de preparo, na área $\mathrm{Al}$.

16 Carta de controle com amplitudes, para a operação de escarificação na linha de preparo, na área A2.

17 Histograma de distribuição da profundidade de escarificação, na linha de preparo, na área A1

18 Histograma de distribuição da profundidade de escarificação, na linha de preparo, na área A2

19 Carta de controle com médias, para a operação de escarificação na entrelinha de preparo, na área $\mathrm{A} 1$

20 Carta de controle com médias, para a operação de escarificação na entrelinha de preparo, na área $\mathrm{A} 2$. 
21 Carta de controle com amplitudes, para a operação de escarificação na entrelinha de preparo, na área A1.

22 Carta de controle com amplitudes, para a operação de escarificação na entrelinha de preparo, na área $\mathrm{A} 2$.

23 Histograma de distribuição da profundidade de escarificação, na entrelinha de preparo, na área $\mathrm{A} 1$

24 Histograma de distribuição da profundidade de escarificação, na entrelinha de preparo, na área A2.

25 Carta de controle com médias, para a operação de gradagem, na área $\mathrm{A} 1$

26 Carta de controle com médias, para a operação de gradagem, na área $\mathrm{A} 2$

27 Carta de controle com amplitudes, para a operação de gradagem, na área $\mathrm{Al}$

28 Carta de controle com amplitudes, para a operação de gradagem, na área $\mathrm{A} 2$

29 Histograma de distribuição do tamanho de torrões, na gradagem, na área $\mathrm{A} 1$

30 Histograma de distribuição do tamanho de torrões, na gradagem, na área $\mathrm{A} 2$ 
32 Histograma dos espaçamentos medidos, para a área A2

33 Histograma dos espaçamentos medidos, para a área $\mathrm{A} 1$, para a unidade 1 da semeadora

34 Histograma dos espaçamentos medidos, para a área $\mathrm{A} 2$, para a unidade 1 da semeadora

35 Histograma dos espaçamentos medidos, para a área $\mathrm{A} 1$, para a unidade 2 da semeadora

36 Histograma dos espaçamentos medidos, para a área A2, para a unidade 2 da semeadora

37 Histograma dos espaçamentos medidos, para a área $\mathrm{Al}$, para a unidade 3 da semeadora

38 Histograma dos espaçamentos medidos, para a área $\mathrm{A} 2$, para a unidade 3 da semeadora

39 Histograma dos espaçamentos medidos, para a área $\mathrm{A} 1$, para a unidade 4 da semeadora

40 Histograma dos espaçamentos medidos, para a área $\mathrm{A} 2$, para a unidade 4 da semeadora 
41 Evolução das alturas médias das plantas de milho, em função dos tratamentos

42 Correlação entre as alturas das plantas de milho, sob os dois tratamentos

43 Produção de massa medida, em função das unidades da semeadora e dos tratamentos

44 Dados das relações espiga/planta e folha/planta, em função das repetições, para a área $\mathrm{A} 1$

45 Dados das relações espiga/planta e folha/planta, em função das repetições, para a área $A 2$

46 Porcentagem do peso retido nas peneiras, e a umidade das amostras colhidas 66

47 Correlação entre a porcentagem do peso retido na peneira superior e a umidades das amostras

48 Correlação entre a porcentagem do peso retido na peneira intermediária e a umidades das amostras

49 Correlação entre a porcentagem do peso retido na peneira inferior e a umidades das amostras

50 Correlação entre a porcentagem do peso retido na peneira superior e o volume da fração 
51 Correlação entre a porcentagem do peso retido na peneira intermediária e o volume da fração

52 Correlação entre a porcentagem do peso retido na peneira inferior e o volume da fração

53 Correlação entre a densidade do peso retido na peneira superior e a densidade original das amostras.

54 Correlação entre a densidade do peso retido na peneira intermediária e a densidade original das amostras

55 Correlação entre a densidade do peso retido na peneira inferior e a densidade original das amostras. 


\section{LISTA DE TABELAS}

Página

1 Análise estatística (teste $\mathrm{T}$ )

para os dados da operação de escarificação

2 Análise estatística (teste $\mathrm{T}$ ) para os dados coletados na linha de preparo do solo e na entrelinha, na operação de escarificação

3 Análise estatística (teste $\mathrm{T}$ ) para os dados da operação de escarificação, na linha de preparo do solo.

4 Análise estatística para os dados da operação de escarificação, na entrelinha de preparo do solo

5 Análise estatística (teste T) para os dados da operação de gradagem

6 Dados estatísticos das unidades semeadoras, coletados a campo

7 Análise estatística (teste T) para os dados da operação de semeadura, a campo

8 Análise estatística (teste T) para os dados de altura de planta

9 Análise estatística (teste Tukey) para os dados da operação de colheita, em análise da produção de massa

10 Análise estatística (ANOVA) para os dados da operação de colheita, em análise da produção de massa 
11 Dados médios das relaç̃oses espiga/planta e folha/planta, para a operação de colheita

12 Análise estatística (teste Tukey) para os dados da operação de colheita, em análise da relação espiga/planta

13 Análise estatística (ANOVA) para os dados da operação de colheita, em análise da relação espiga/planta

14 Análise estatística (ANOVA) para os dados da operação de colheita, em análise da relação folha/planta

15 Análise estatística (ANOVA) para os dados da operação de colheita, em análise da relação folha/planta 


\title{
APLICAÇÃO DE CONCEITOS DA QUALIDADE EM OPERAÇÕES MECANIZADAS NA PRODUÇÃO DE MILHO (Zea mays L.) PARA SILAGEM
}

\author{
Autor: RICARDO ALVES THOMAZ FERNANDES
}

Orientador: Prof. Dr. MARCOS MILAN

\section{RESUMO}

Atualmente, na economia globalizada, é necessário ser eficiente para sobreviver e estar entre os melhores. Dentro desta realidade, visa-se o lucro a custos baixos, porém é imprescindível acompanhar e incentivar a evolução da mão-de-obra para que o nível de excelência seja alcançado. As empresas agropecuárias devem profissionalizar-se e buscar novas técnicas de gerência administrativa e operacional para enfrentar a concorrência sem barreiras instalada no mundo. $O$ controle estatístico de processos (CEP) é um conjunto de ferramentas muito útil e simples para ser utilizado na agropecuária nacional, pois consiste em análises e amostragens em tempo real das operações com correções e ajustes, caso sejam necessários. Com base nisso, o CEP foi implantado num sistema de produção de milho para silagem, avaliando as operações de preparo de solo, a distribuição de plantas e a colheita, assim como o desenvolvimento da cultura ao longo de todo o ciclo, adaptando-se algumas metodologias e dispositivos desenvolvidos. A metodologia das ferramentas do CEP utilizada foi a sugerida por Kume (1993) e Vieira (1999), e a instalação dos experimentos adaptada à agricultura foi seguida conforme técnicas desenvolvidas por Peche Filho et al. (1994) e Fernandes (1997). A implantação do CEP na operação de escarificação proporcionou uma redução 
da variabilidade de dados de profundidade de trabalho média em $38,4 \%$ e um aumento de $45,0 \%$ dos dados na faixa de valores desejada. Quando os dados foram estratificados, houve redução de $10,3 \%$ da profundidade medida na linha de preparo do solo e aumento de $15,3 \%$, na entrelinha das hastes. Na gradagem, houve redução de $9,8 \%$ dos dados médios de tamanho de torrões, e ainda verificou-se um aumento de $75,0 \%$ de torrões aceitáveis (menores que $4,0 \mathrm{~cm}$ ) e redução de $91,7 \%$ dos torrões de diâmetro grande (maiores que 9,0 cm). No espaçamento entre plantas, observou-se um acréscimo de $8,2 \%$ de espaçamentos desejados com a implantação do CEP, no preparo de solo. Ao se avaliar as unidades da semeadora, verificou-se um comportamento distinto nos padrões de espaçamentos verificados. A diferença entre as alturas de plantas para os tratamentos foi significativa, assim como a relação entre peso das folhas e da planta; entretanto, o mesmo não aconteceu com a relação entre peso da haste e peso da planta e densidade dos colmos. Os dispositivos adaptados e desenvolvidos para a checagem das operações mecanizadas mostraram-se adequados para as tarefas propostas a campo; assim como a utilização de conceitos do controle estatístico de processos para o sistema de produção de milho para silagem analisado. 


\title{
QUALITY CONCEPTS APPLICATION AT MECHANIZED CORN SILAGE (Zea mays L.) OPERATIONS
}

\author{
Author: RICARDO ALVES THOMAZ FERNANDES \\ Adviser: Prof. Dr. MARCOS MLAN
}

\section{SUMMARY}

Nowadays, efficiency is indispensable to survive in economy. To be aligned to this reality, profit at lower costs is essential and to reach this level is necessary stimulating workers evolution. The agricultural companies must have a professional commerce management and competitive operational techniques to face competition in the world commerce. The statistical process control (SPC) is a useful and simple tool ready to be used by Brazilian farmers, because it is based on real-time operations, analysis and samplings, providing adjustments and corrections, if needed. Based on this, SPC was implemented in a corn silage production system, evaluating tillage, plant distribution and harvest operations, as well as the corn growth during its whole cycle. Some methodologies and devices had to be developed to analyze the system. The applied SPC methodology was suggested by Kume (1993) and Vieira (1999), and the experimental installation was followed according to techniques suggested by Peche Filho et al. (1994). The SPC implementation at chisel operation provided a $38,4 \%$ data average variability decrease and increased the desired data in 45,0\%. Analyzing the split data, a depth reduction was verified in 10,3\% of direct action data and a $15,3 \%$ increase was observed in indirect action data. At the harrow operation, SPC provided a 9,8\% 
average diameter reduction, increased in $75,0 \%$ the desired stone diameter rate in the area and almost extinguish the large stones with a 91,7\% decrease rate. A 8,2\% increase at the desired distribution was observed when SPC was implemented. Although, several distribution patterns were displayed when each of seedling devices of the planter were sampled. Corn growth differences and leaves/plant rate were significant, however the same did not occur with stalk/plant rate and stalk density. The developed devices appeared to be fitted to check the mechanized operations parameters in field; as well the quality concepts application at mechanized corn silage operations for this production system. 


\section{INTRODUÇÃo}

$\mathrm{Na}$ economia globalizada dos dias atuais, onde a informação muda de mãos em segundos, exige-se indivíduos cada vez mais capacitados, prontos para as mudanças incessantes do pensamento gerencial, e sobretudo aptos para sobreviverem em mercados tão acirrados e competitivos. As empresas, para conseguirem firmar-se, devem lançar mão de renovação dos recursos humanos e sobretudo mudar a filosofia interna de trabalho, visando o sucesso pela qualidade.

A competição não tem barreiras fiscais ou geográficas. Para obter-se sucesso, os produtos e/ou serviços necessitam ser produzidos com qualidade e a baixo custo, tanto para o fabricante (produtor ou prestador de serviço) como para o consumidor (cliente).

A agricultura e pecuária brasileiras vêm passando pelas mesmas mudanças, assumindo uma postura cada vez mais profissional e competitiva, incorporando novas tecnologias e buscando a redução dos custos de produção.

Para a maioria das culturas agrícolas, em contraponto à indústria, os preços pagos aos produtores são fixados pelo mercado vigente, influenciados pela economia de outros centros produtores e pelo nível dos estoques mundiais. Não controlando esses preços, a maneira de o produtor aumentar a lucratividade é através da redução dos custos de produção. Quanto à pecuária, a imposição de leis restringindo o trânsito de rebanho entre estados brasileiros e o acirramento da concorrência com produtos similares (como as carnes de frango e suína), vêm obrigando os pecuaristas a aplicarem técnicas de redução de custos e melhoria da produtividade, tanto do rebanho, quanto da cultura forrageira ou suplementar.

As operações mecanizadas de um sistema de produção, seja agrícola ou pecuário, representam um ponto estratégico para o desenvolvimento destas técnicas, pois os custos 
com máquinas para as principais culturas anuais podem variar de $21,7 \%$ a $40,5 \%$ do total de produção, segundo pesquisadores do Instituto de Economia Agrícola (IEA), com dados referentes ao Estado de São Paulo, em 1996.

A aplicação de ferramentas do Controle Estatístico da Qualidade (CEQ), tais como o Controle Estatístico de Processos (CEP), largamente utilizadas no setor industrial, ao serem adequadas ao setor agropecuário, podem contribuir para a redução de custos, permitindo manter os padrões desejados e identificar problemas de difícil percepção pela rotina operacional empregada.

Alguns trabalhos já vêm sendo realizados por instituições de pesquisas, enfocando esse aspecto. Culturas como o milho (Zea mays L.), batata (Solanum tuberosum L.) e cana-de-açúcar (Saccharum spp.), conhecidas por sua importância na economia de São Paulo, foram estudadas, sob o ponto de vista da qualidade de processos. Os trabalhos confirmam a viabilidade da aplicação do Controle Estatístico de Processos (CEP) na agricultura, bem como visualiza-se a possibilidade de seu desenvolvimento tanto nas metodologias a serem adotadas, quanto na avaliação dos custos de implantação do mesmo.

Apesar do crescente interesse nesse assunto, por parte de pesquisadores $\mathrm{e}$ profissionais do setor agropecuário, ainda não existe uma quantidade suficiente de trabalhos a respeito no gênero, sendo necessária a adaptação e criação de metodologias para suprir a necessidade de cada sistema de produção.

Com esse enfoque, esse trabalho foi desenvolvido com o objetivo de analisar os efeitos da utilização de técnicas do controle de qualidade em operações agrícolas na cultura do milho para a produção de silagem. Como objetivos específicos, destacaram-se o desenvolvimento de padrões e de dispositivos para aferições da qualidade nas operações. 


\section{REVISÃO DE LITERATURA}

\subsection{CONCEITOS DE QUALIDADE}

\subsubsection{Qualidade: definição}

De acordo com Juran (1990) e Montgomery (1996), existem muitos sentidos e definições da palavra qualidade. Para os autores, uma definição simples é quanto a adequação ao uso. Durante todo o processo em andamento, existem muitos usuários ou clientes participantes, ou seja, pessoas afetadas pelo processo ou produto. Esses clientes podem ser internos (participantes da produção) ou externos (recebem o produto ou serviço). Desse modo, para cada fase em questão, a qualidade agregada deve estar apropriada ao cliente.

Qualidade é um julgamento feito pelos clientes ou usuários de um produto ou serviço; é o grau em que clientes ou usuários sentem que o produto ou serviço excede suas expectativas (Gitlow, 1993).

Outra definição aceita para qualidade é a redução da variabilidade. Quanto menor for esta, melhor será a confiabilidade do produto ou serviço e maior será a aceitação do mesmo; a variabilidade pode ser entendida como desperdício de dinheiro, tempo e esforços (Montgomery, 1996).

\subsubsection{Rotina, melhoria e produtividade}

Juran (1995), descreve que a palavra controle significa permanecer no curso, firmeza nos padrões, prevenção de mudanças. Quando tudo está sob controle, nada 
poderá mudar, haverá a estática, um mundo paralisado. $\mathrm{E}$ ainda, afirma que a palavra melhoria significa mudança, um dinâmico e decisivo momento para novos e altos níveis de atividade. $\mathrm{O}$ autor conclui que um gerente ou administrador deve focar seu trabalho aliando controle e melhoria, e nada mais. Deve-se sempre buscar novos patamares de qualidade no serviço ou produto da atividade, mantê-los estáveis e sob controle, para depois se alcançar um novo estágio de qualidade ou excelência. É importante ressaltar que, para uma empresa alcançar um nível de qualidade desejado (ou exigido), as técnicas gerenciais devem alternar a fase de melhoria com a de controle.

Rotina e melhoria são, ambas, necessárias se uma empresa pretende ser competitiva no futuro. A melhoria dos processos modifica produtos e processos existentes, para reduzir continuamente a diferença entre as necessidades do cliente e o desempenho do processo (Gitlow, 1993; Bonilla, 1994).

Gitlow (1993) ainda observa que melhoria e produtividade não têm a mesma definição, já que pode-se aumentar a qualidade sem necessariamente aumentar a produtividade. Em muitos casos, quando a produtividade é aumentada, a qualidade não a acompanha porque não deu-se atenção às melhorias do processo, nem às condições de trabalho do operador, o fator humano.

\subsubsection{O controle estatístico de processos (CEP)}

Um aspecto fundamental do controle de qualidade é o conceito de rompimento, que implica em mudança de forma de pensar, de estilo e de postura, envolvendo todos os níveis administrativos da empresa agropecuária, desde o presidente até o último trabalhador (Bonilla, 1994).

Gerenciar ou controlar um processo é o ato de buscar as causas (meios) da impossibilidade de se atingir uma meta (fim), estabelecer contramedidas (plano de ação) e padronizar em caso de sucesso. Para Campos (1994), é necessário estabelecer um bom gerenciamento que vise manter os resultados alcançados com as melhorias. Para isso, o autor enfatiza que o método de gerenciamento de processos mais adequado para isso seria o controle estatístico de processos (CEP). 
Brassard (1996) cita também que umas das técnicas avançadas para um controle da qualidade em um sistema de produção é o controle estatístico de processos (CEP). Este conjunto de ferramentas não só é capaz de analisar os processos, como também pode avaliar o serviço realizado pelos operadores envolvidos, contribuindo para a evolução do fator humano.

Mirshawka (1988) define controle estatístico de processos (CEP) como sendo uma maneira lógica de se pensar, em todos os níveis de operações para produção ou prestação de um serviço. Convenientemente aplicadas, as técnicas do controle do processo fornecem a oportunidade e os meios de se fazer efetivamente a prevenção de defeitos ou erros antes mesmo que eles ocorram. Também, pode ser visualizada como um conjunto de técnicas muito mais eficaz e confiável do que as técnicas de inspeção por amostragens terminais. As vantagens da introdução do CEP são o surgimento do conhecimento significativo e a compreensão dos seus processos; a dependência da inspeção em massa pode ser eliminada, ou ao menos, substancialmente reduzida; os custos da qualidade (tais como refugo, retrabalho e retornos) podem ser reduzidos, as programações de operação cumpridas e, como resultado, surgem ganhos claros na produtividade; pode-se dialogar e se comunicar de uma forma mais eficiente com a engenharia, influenciando dessa forma o planejamento do projeto e surgindo dá tolerâncias mais significativas.

Bonilla (1995) e Montgomery (1996) ainda ressaltam que o controle estatístico de processos é um conjunto de poderosas ferramentas úteis para a resolução de problemas para o alcance da estabilidade do processo e aumento da capacidade através da redução da variabilidade. O CEP pode ser aplicado a qualquer processo e são sete as suas ferramentas mais importantes: histograma, folha de verificação, gráfico de Pareto, diagrama de causa e efeito, gráfico de correlação, gráfico de controle e estratificação. 


\subsubsection{Alguns conceitos do controle estatístico de processos (CEP)}

\subsubsection{Cartas de controle}

As cartas de controle são muito usadas por refletirem a variabilidade existente no sistema. São gráficos de acompanhamento compostos pelo limite superior de controle (LSC), e pelo limite inferior de controle (LIC), paralelas a uma linha que representa a média obtida das medições dos atributos analisados. $O$ fato de se utilizar um grupo de dados resulta em menor variação do que em amostras individuais, imprimindo maior confiabilidade aos dados (Kume, 1993).

Quando a flutuação dos pontos plotados na carta ocorre dentro dos limites, diz-se que o processo está sob controle e que as variações existentes são devidas a causas comuns dentro do sistema. Este tipo de variação faz parte da natureza do sistema, segue padrões normais de comportamento e pode ser controlada por mudanças no próprio sistema. No entanto, se pontos são plotados fora dos limites de controle (LSC ou LIC), diz-se que ocorreram causas especiais no processo, uma vez que se está utilizando apenas números médios, desprezando-se os extremos; assim, pontos só são plotados fora dos limites de controle se causas externas ao sistema estiverem atuando sobre ele. Estas causas são imprevisíveis e merecem investigação da gerência do processo ou serviço. Elas resultam do setor operacional e conduzem a problemas ocasionais como erro humano, quebra de ferramenta, acidentes entre outras (Kume, 1993; Montgomery, 1996).

São critérios indicativos de falta de controle de um processo a presença de pontos fora dos limites de controle, periodicidade, sequiência ou tendência dos dados plotados, aproximação dos limites de controle ou aproximação da linha média (Kume, 1993; Dellaretti Filho \& Drumond, 1994; Werkema, 1996).

Dellaretti \& Drumond (1994) esclarecem ainda que, para as indicações de processo fora de controle, existem causas especiais, tais como desgaste de ferramentas de produção ou aferição, mudança gradual ou abrupta nas condições ambientais, mudança dos parâmetros do processo, uso de matéria-prima de qualidade diferente, 
operários utilizando metodologias diferentes, fadiga do operador, erros de cálculos ou misturas de dados. De acordo com Brassard (1996), um processo é dito fora de controle quando (Figura 1):

a) Um ou mais pontos caem fora dos limites de controle;

b) Dois pontos, em três sucessivos, de um mesmo lado da linha central (média), na zona A ou acima desta;

c) Quatro pontos, em cinco sucessivos, de um mesmo lado da linha central, na zona B ou acima desta;

d) Nove pontos sucessivos de um mesmo lado da linha central;

e) Seis pontos consecutivos ascendentes ou descendentes;

f) Quatorze pontos numa série alternando para cima e para baixo;

g) Quinze pontos numa série dentro da zona C (acima e abaixo da linha central).

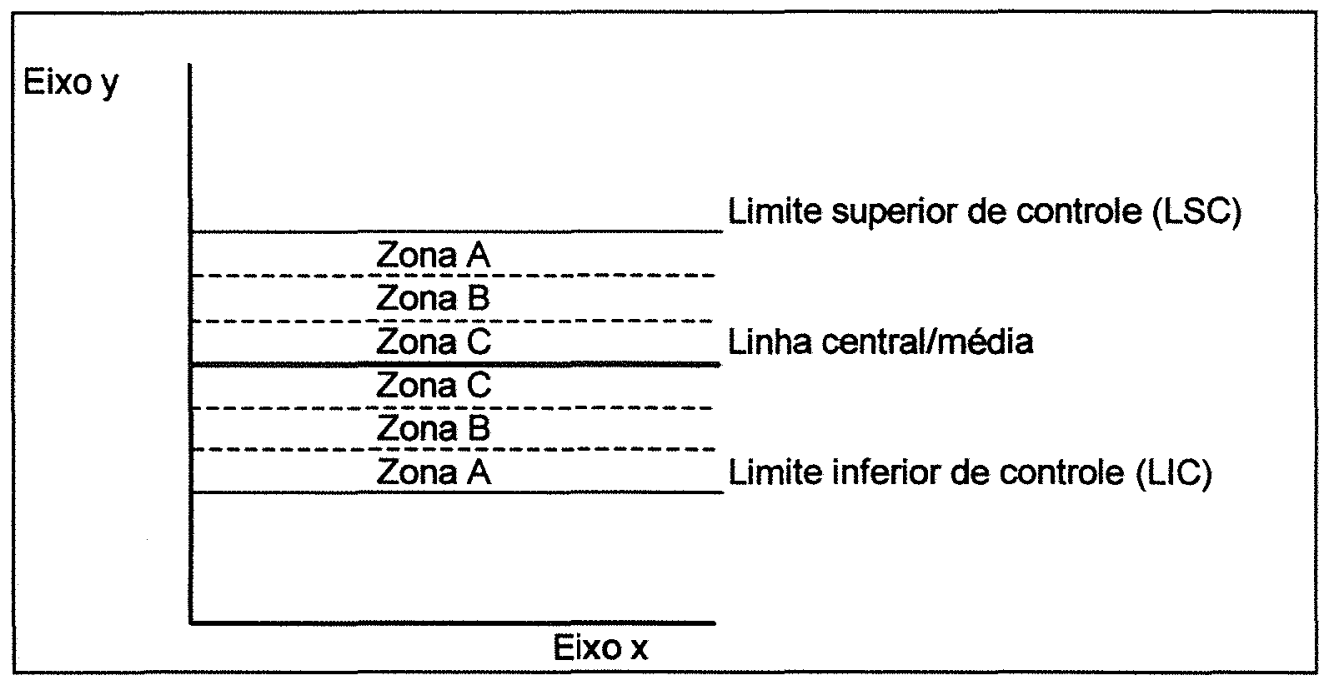

Figura 1 - Esquema de uma carta de controle e suas zonas espaciais.

\subsubsection{Histogramas}

Um histograma envolve a medição de dados e mostra sua distribuição, revelando o quanto de variação existe em qualquer processo. Um histograma típico deve apresentar um distribuição do tipo normal, na qual a maioria dos dados concentra-se em torno da 
medida central, e um igual número de medidas situa-se de cada lado deste ponto. Várias amostras aleatórias de dados sob controle estatístico seguem o modelo conhecido como "curva de sino". Outras, formas ocorrem, com o acúmulo de dados em pontos afastados do ponto central. Tais distribuições são chamadas inclinadas. Além da inclinação, devese observar a variação dos dados e a ocorrência de picos duplos, o que indica que os dados provêm de duas ou mais fontes, isto é, diferentes turnos, máquinas, etc. (Brassard, 1996).

As diversas configurações de um histograma chamam a atenção para a mistura de dados e um controle desigual dos limites que podem levar a uma apresentação diferente da típica. Dentre os tipos citados estão: geral (mais comum), pente (multi-modal), assimétrico positivo, abrupto à esquerda, achatado, picos duplos (bimodal) e pico isolado (Kume, 1993; Dellaretti Filho \& Drumond, 1994).

\subsubsection{Diagramas de dispersão}

Os diagramas de dispersão são utilizados para estudar a relação entre duas variáveis associadas. As duas variáveis devem ser uma característica e um fator que a afeta; duas características que se relacionam ou dois fatores que se relacionam com a mesma característica (Kume, 1993).

Werkema \& Aguiar (1996), de outra forma, observam que a análise de dispersão pode ser utilizada com vários objetivos, dentre os quais é possível destacar: descrição, predição, controle e estimativa. Deste modo, além de se estudar a correlação entre as variáveis de um processo pode-se estimar numericamente sua equação, o índice de correlação e determinar a confiabilidade da relação entre ambas.

Para se analisar um diagrama de dispersão, inicialmente deve-se examinar se não há pontos atípicos. Julga-se atípico, todo ponto discrepante do grupo principal, resultante de erro de medição ou registro de dados ou mudança de condições de operação. É necessário excluir esses pontos para análise correta da correlação. Contudo, ao invés de desprezar completamente os pontos, deveria ser dada a devida atenção à causa de tais 
irregularidades pois, muitas vezes, informações inesperadas, porém muito úteis, são obtidas descobrindo-se porque eles ocorreram (Kume, 1993).

\subsection{Os CUSTOS DA QUALIDADE}

De acordo com Mirshawka (1988), a implantação de um sistema de controle de qualidade em um processo produtivo não implica necessariamente em aumento demasiado dos custos de produção. Qualidade insuficiente ou não-qualidade significa uma utilização inadequada de recursos, perdas e gastos desnecessários de material, mãode-obra e máquinas, resultando em um aumento do custo do produto ou serviço. Atualmente, os custos da qualidade podem ser isolados para uma mensuração confiável, em uma gestão eficaz e rigorosa de controle de qualidade ou mesmo de uma empresa. Os custos da qualidade são os relativos à definição, criação e controle da qualidade, incluindo a avaliação do trabalho realizado na constatação da conformidade com as normas da qualidade, da segurança e da confiabilidade. São também os custos que resultam como conseqüência de falhas internas (entre os setores ou departamentos) ou externas, ou seja, com os clientes.

Montgomery (1996) enfatiza que, numa primeira classificação, pode-se subdividir os custos da qualidade em:

I) custos de controle

a) custos da prevenção

b) custos da inspeção e da avaliação da qualidade

II) custos da falha de controle

a) custos das falhas internas

b) custos das falhas externas

Os custos de prevenção e inspeção e avaliação da qualidade são chamados de custos diretos (controláveis) da qualidade, os custos da falha de controle são chamados de custos indiretos (incontroláveis) da qualidade. Na prática, as falhas internas e externas representam de 65 a $75 \%$ dos custos da qualidade, 20 a $25 \%$ são atribuídos a 
custos de avaliação e, em muitas empresas, os custos de prevenção não ultrapassam $10 \%$ do custo total da qualidade (Mirshawka, 1988).

Almeida (1995) acrescenta que a tendência ao longo da melhoria de processos é haver uma redução do custo da qualidade. Os custos de prevenção tendem a aumentar de proporção entre as partes, os de deteç̧ão mantêm-se e o de reação (se existirem) tendem a zero. Tudo isso devido ao aumento de treinamento dos recursos humanos em qualidade e à conseqüente redução de falhas e desperdícios. $\mathrm{O}$ custo da qualidade nunca será zero. Idealmente, haverá sempre a parcela de prevenção. E esse custo deve ser utilizado para aferir a evolução de uma mesma atividade ou de um mesmo setor, no decorrer do tempo, sempre para a manutenção do controle eficaz e atuante.

\subsection{A QUALIDADE APLICADA NA AGROPECUÁRIA}

\subsubsection{A qualidade por toda a cadeia agroalimentar}

Para Toledo (1997), a qualidade de um produto agroalimentar tem duas características marcantes. A primeira refere-se aos parâmetros e exigências de qualidade que são ocultas, ou seja, aqueles que o consumidor não enxerga, mas que, de alguma forma, podem prejudicá-lo. Esses parâmetros encontram-se em normas e regulamentações oficiais e referem-se aos padrões microbiológicos, à ausência de substâncias nocivas e à sanidade do produto em geral. Outra característica do produto agroalimentar refere-se à importância dos padrões de qualidade de apresentação, ou representação, para a decisão de compra do produto.

Toledo (1997) afirma ainda que, resumidamente, as especificidades da qualidade no sistema agroalimentar são:

- a qualidade do produto final depende da qualidade ao longo de toda a cadeia alimentar.

- na ponta final da cadeia agroalimentar predomina a avaliação subjetiva da qualidade, ou seja, a percebida pelo consumidor.

- segurança é um aspecto fundamental da qualidade e está sujeita ao controle de 
órgãos públicos.

Em relação à primeira especificidade, faz-se necessária a coordenação das ações, que influem na qualidade final ao longo de toda a cadeia, e à conscientização de que a gestão da qualidade de uma unidade de produção deve transcender os limites da mesma. Assim, é fundamental a incorporação de conceitos, tais como: enfoque sistêmico, qualidade total na cadeia, coordenação das ações da qualidade, relação clientefornecedor, sistemas de garantia da qualidade (ISO 9000) e boas práticas de manufatura, produção e higiene (Toledo, 1997).

No Quadro 2, pode-se visualizar a importância de diversos parâmetros da qualidade da carne bovina, conforme os segmentos da cadeia produtiva.

Quadro 2. Parâmetros da qualidade da cadeia bovina, conforme os segmentos da cadeia produtiva.

\begin{tabular}{ll}
\hline \multicolumn{1}{c}{ Macrossegmento } & \multicolumn{1}{c}{ Critério (parâmetro) de qualidade } \\
\hline Produtor rural & - Peso vivo \\
& - Conformação e tempo de engorda do animal \\
& - Peso da carcaça e rendimento \\
\hline Indústria frigorífica & - Conformação e tempo de engorda da carcaça \\
& - Raça e idade \\
\hline Açougues & - Rendimento de carne comercializável \\
& - Cor \\
\hline Consumidor & - Maciez \\
& - Teor de gordura \\
\hline
\end{tabular}

Fonte: Adaptado de Nicolas \& Valceschini (1995).

Segundo Nicolas \& Valceschini (1995), a qualidade é atualmente um dos objetivos prioritários dos empreendimentos agropecuários, porém nem sempre é introduzido ao nível estratégico. A introdução da qualidade nos setores de distribuição permite uma melhoria na competitividade e uma diminuição dos custos, uma vez que os produtos com qualidade diferenciada são melhor percebidos e aceitos pelos 
consumidores finais. Os custos da "não qualidade" são os da má qualidade (propriamente dita) dos produtos, aumento de estoques, interrupção do processo produtivo e o custo de manejo de refugos, entre outros.

Não existe uma qualidade média dos produtos agrícolas ou alimentares. Cada macrossegmento da cadeia deve procurar produzir um produto padronizado, ou se necessário, um produto diferenciado, visando atender uma demanda segmentada para a satisfação dos clientes (Nicolas \& Valceschini, 1995).

\subsubsection{Controle de qualidade em operações agrícolas}

Em um estudo sobre controle de qualidade em operações mecanizadas na cultura de cana-de-açúcar (Saccharum spp.), analisando as operações de sulcação (plantio) e carregamento (colheita), Lopes et al. (1995) concluíram que o índice de variação encontrado nas áreas analisadas foi muito elevado. No caso do espaçamento entre sulcos, a variação entre os diversos grupos estudados está fora de controle, apesar da média estar próxima da desejada para a operação, sugerindo problemas de má regulagem de implemento ou erros na operação.

Em avaliação de desempenho de plantadora de batatas (Solanum tuberosum), Silva et al. (1996) utilizaram ferramentas de controle de qualidade em operações agrícolas para a determinação de padrões de qualidade da máquina, medindo quantidade e posição da distribuição do adubo em relação ao tubérculo, tubérculos por metro linear, espaçamento longitudinal e profundidade de tubérculos. Os resultados foram satisfatórios, apesar de haver falhas devidas ao fato da máquina ser importada e não estar adaptada ao solo brasileiro.

A utilização do controle estatístico da qualidade para teor de impurezas minerais em carregamentos de cana-de-açúcar mostrou-se eficaz para detecção de cargas anormais (primeiro passo para identificar e corrigir as causas especiais assinaláveis dos altos níveis de impurezas minerais), para a visualização ampla do sistema de produção e para detectar problemas de falta de normalidade (Sarriés, 1997). 
Fernandes (1997), trabalhando em gerenciamento da qualidade em operações agrícolas mecanizadas de um sistema de produção de cana-de-açúcar (Saccharum spp.), observou que apesar da operação de subsolagem estar sob controle estatístico, encontrava-se com valores de profundidade de trabalho não compatíveis com as especificações da empresa. Em talhões amostrados, denominados A, B e C, apenas $26,67 \%, 26,67 \%$ e $16 \%$ dos pontos, respectivamente, encontravam-se dentro do intervalo padrão de 45,0 a $50,0 \mathrm{~cm}$, desejado para a operação. A variação de valores encontrada, também foi considerada excessiva, onde o indicador mais baixo foi de 43,0 $\mathrm{cm}$ e o mais alto, $61,0 \mathrm{~cm}$. $\mathrm{Na}$ análise da qualidade da pulverização de herbicidas em cana-soca, em apenas $32 \%$ da área foi aplicada a concentração ideal de gotas, e em mais de $50 \%$ da área houve uma deposição excessiva de gotas.

Avaliando a influência de indicadores de qualidade no custo operacional de um sistema de produção de milho, Dodson (1998) demonstrou que em um estudo de caso, a semeadura encontrava-se fora os padrões preestabelecidos. Apenas $56 \%$ dos valores estavam dentro das especificações (entre 4 e 6 sementes $/ \mathrm{m}$ ). Além disso, o autor atestou que somente $40 \%$ das sementes estavam dentro do espaçamento horizontal desejado (de 20,0 a 33,0 cm entre sementes). Deste modo, a lavoura de milho desenvolveu-se sem uniformidade, com a possibilidade de existirem problemas com surgimento de plantas daninhas em espaços não ocupados pela planta de milho $\mathrm{e}$, onde houvesse um número excessivo de sementes, a produtividade por área seria reduzida.

Em pesquisas sobre o gerenciamento da qualidade em operações agrícolas mecanizadas em um sistema conservacionista de produção de milho, Pasqua (1999) constatou que, em um estudo de caso de semeadura, o índice médio de qualidade da mesma foi $62,4 \%$, sendo classificada como regular, sendo que $20 \%$ dos espaçamentos ficou abaixo do ideal; e 17,6\%, acima do espaçamento desejado. Também, a autora verificou que a profundidade de semeadura sofreu grande variação, havendo desde sementes sem cobertura (profundidade zero) até sementes a $8,5 \mathrm{~cm}$ de profundidade, gerando desuniformidade na emergência das plântulas e, por conseqüência, irregularidade no stand na lavoura. 
Lino et al. (1999), em análise da fragmentação de fitomassa realizada por uma roçadora em área com predominância de capim-colonião, utilizaram conceitos preconizados pelo controle estatístico da qualidade. Os autores observaram grande variabilidade da distribuição da fitomassa, cuja média foi de $1.796 \mathrm{~kg} / \mathrm{ha}$ e alto coeficiente de variação $(77,54 \%)$. Quanto ao tamanho dos fragmentos, a média encontrada foi de 19,04 cm, sendo que a amplitude foi dez vezes maior esse valor, entretanto o coeficiente de variação foi baixo, 19,07\%. Assim, concluíram que a metodologia aplicada foi suficiente e adequada para a caracterização da área antes e depois da operação.

\subsection{FATORES QUE INFLUENCIAM A QUALIDADE E PRODUÇÃO DA SILAGEM}

\subsubsection{Escolha do híbrido ou cultivar}

De acordo com Hunter (1978), a maioria dos produtores de milho para silagem nos Estados Unidos e Europa aceitaram o fato de que os genótipos com melhor produção de grãos são também os mais adequados para a produção de massa. Os três principais objetivos na produção de massa são a alta quantidade de matéria seca por unidade de área cultivada, o alto consumo animal e o alto valor nutritivo.

Nussio (1991) destaca algumas vantagens apresentadas pelos híbridos precoces de menor ciclo vegetativo, as quais são:

a) boa produtividade de grãos por possibilitar aumento na população de plantas por unidade de área, devido ao porte reduzido das plantas;

b) possibilidade de se semear duas culturas no ano agrícola com melhor aproveitamento agrícola;

c) melhor aproveitamento de mão-de-obra, máquinas e implementos;

d) melhor adequação às regiões, como o oeste do Paraná, onde é possível a semeadura do milho completamente fora de época;

e) semeadura antecipada para escapar do veranico, especialmente na região Sul do Brasil. 
Estudos recentes mostraram que, enquanto o milho de características tropicais (ciclo normal) apresenta em torno de $38 \%$ de grãos na matéria seca, os híbridos precoces tendem a apresentar 50\%, mostrando-se assim, mais eficientes na conversão de energia em grãos (Nussio, 1991).

\subsubsection{Preparo de solo}

Observando os efeitos da compactação do solo no desenvolvimento e produtividade do milho, Raghavan et al. (1978) observaram que existiam diferenças de até 50\% na altura medida das plantas em alguns tratamentos mais severos. As pressões mais severas $(617,4 \mathrm{~Pa})$ de tráfego de máquinas causaram atrasos na floração, enquanto que tratamentos com pressões menores $(313,6 \mathrm{~Pa})$ não induziram atrasos até 5 a 10 passadas de máquinas. A redução de produtividade chegou a até $50 \%$ em tratamentos muito compactados, comparados ao tratamento padrão (sem tráfego). As características de crescimento da planta se mostraram fortemente dependentes da magnitude da pressão de contato dos pneumáticos com o solo e do número de passadas das máquinas sobre o solo em cada tratamento.

Conduzindo experimentos sobre os efeitos do tráfego de máquinas e operações de cultivo sobre as propriedades físicas de um solo argiloso e sobre as produtividade de silagem de milho, McKyes et al. (1979) observaram que em solos compactados, a utilização do subsolador aumentou a condutividade hidráulica quando comparado com o escarificador, apesar dos agregados deste serem menores que os encontrados no primeiro. Também, a produtividade do milho foi maior em solos compactados preparados com subsolador, anteriormente.

Realizando estudos com as propriedades fisicas e produtividade da silagem de milho, afetadas pela compactação e métodos de cultivo do solo, Anazodo et al. (1983) obtiveram resultados mostrando que a compactação do solo causada pelo tráfego não afetava a constituição, nem a resistência mecânica das espigas, mas que o diâmetro foi significativamente afetado. Ainda, constataram que a produtividade das espigas sofre influência direta do nível de compactação do solo. Assim, o melhor método de 
descompactação utilizado foi a subsolagem, a fim de minimizar os efeitos limitantes sobre o crescimento da espiga.

Ibrahim \& Miller (1989), estudando os efeitos da subsolagem sobre a qualidade e produtividade de milho, constataram que a planta tendia a crescer mais em solos subsolados, comparados àqueles somente gradeados, resultando em uma melhor qualidade de silagem, principalmente na ocorrência de períodos de deficiência hídrica.

Wagger \& Cassel (1993), pesquisando os efeitos do cultivo e irrigação sobre a produtividade de milho e a eficiência do uso da água, concluíram que, em uma situação de deficiência hídrica, plantas de solos cultivados tendiam a produzir mais espigas de maior peso que as em solos sem cultivo.

Avaliando a qualidade do preparo do solo com grade em função de regulagens e da utilização de discos esféricos e cônicos, Boller et al. (1995) verificaram que a profundidade de ação dos discos aumentou, enquanto a porcentagem de cobertura do solo com resíduos diminuiu, quando o ângulo de travamento entre as seções foi aumentado. No menor e maior ângulo, os discos cônicos produziram menores percentagens de agregados na classe de 4,0 a $8,0 \mathrm{~cm}$ de diâmetro. $O$ aumento do ângulo de travamento entre as seções resultou em aumentos de porcentagens de agregados maiores que 19,3 cm, ao passo que, para as classes menores que $19,3 \mathrm{~cm}$, o inverso ocorreu.

\subsubsection{Semeadura}

Citando um estudo realizado no Estado de Michigan (EUA), Nussio (1991), relata que ficou demonstrado que a cada dia de atraso na semeadura à partir do primeiro dia de estação de crescimento, a perda estimada de grãos foi na ordem de $65 \mathrm{~kg} / \mathrm{ha}$. Essas informações são concordantes com os dados obtidos pelas empresas produtoras de sementes no Brasil, que demonstram queda de 5 a $10 \%$ de grãos quando se compara a semeadura na segunda quinzena de outubro com a da primeira. Esse fato pôde ser explicado pelo anacronismo da maturação das estruturas reprodutivas da planta de milho, quando submetidas a semeaduras tardias, prejudicando a floração e a polinização. 
Fisher \& Fairey (1982), desenvolvendo estudos sobre o efeito de densidades populacionais no valor nutritivo da silagem de milho para vacas em lactação, concluíram que a densidade de 100.000 plantas/ha apresenta $10 \%$ a mais de espigas na composição, resultando em uma silagem de maior digestibilidade, causando uma redução do teor de gordura no leite produzido $(17,32 \%)$.

Analisando os resultados coletados de ensaios realizados em 16 locais do Estado de Michigan (EUA), Erdmann \& Hildebrand (1975), citados por Penati (1995), observaram que o aumento da população de plantas $(38.000,47.500,57.300$ e 68.000 plantas/ha) provocou respectivamente as seguintes alterações nas produções de grãos: $8.040,8.549,9.431$ e $8.725 \mathrm{~kg} / \mathrm{ha}$ para o ano de 1975 e de $6.010,6.798,6.565$ e 6.061 $\mathrm{kg} / \mathrm{ha}$ para o ano de 1976. Em outro ensaio com milho, com populações muito semelhantes ao trabalho anterior, quando a irrigação foi executada, as médias das produções de grãos de 5 anos (1968 a 1972), para as 4 populações foram respectivamente de: $9.009,10.647,11.403,10.332 \mathrm{~kg} / \mathrm{ha}$ para o tratamento com irrigação, e de $5.859,6.867,5.859$ e $5.229 \mathrm{~kg} /$ ha para o tratamento sem irrigação. Observa-se que quando a irrigação foi utilizada, as produções mais elevadas ocorreram quando a população atingiu 57.300 plantas/ha, ou seja, em situação onde não houve deficiência hídrica, pode-se aumentar a população para aumentar a produção de grãos.

A maior limitação para a alta produção de grãos em altas densidades populacionais é a alta freqüência de plantas sem espiga. Com o aumento do sombreamento mútuo, as plantas podem ficar menores e alterações metabólicas ocorrem, alterando a composição da parte aérea. Em alguns híbridos a planta reage ao acréscimo populacional aumentando de altura. Essa mudança deixa as hastes mais finas e, portanto, mais suscetíveis ao acamamento. Fica caracterizado que o aumento populacional excessivo implica em redução da produção de grãos e da proporção dos mesmos na planta, de acordo com Nussio (1991).

Pozar \& Zago (1990), citados por Penati (1995), ao trabalharem com 7 híbridos em 4 populações $(30.000,55.000,80.000$ e 105.000 plantas/ha), verificaram que o aumento da população provocou aumento na produção de matéria verde (MV) de 46.100 para $67.400 \mathrm{~kg} / \mathrm{ha}$, para 30.000 e 105.000 plantas/ha, respectivamente, e a produção de 
matéria seca (MS) aumentou de 11.600 para $16.100 \mathrm{~kg} / \mathrm{ha}$. Com relação à estrutura física da planta, o aumento da densidade de plantas causou um aumento da porcentagem de haste na matéria seca (MS) de $29,4 \%$ para $36,0 \%$, a porcentagem de espigas caiu de $30,8 \%$ para $23,5 \%$, enquanto que a relação de folhas na matéria seca (MS) da planta permaneceu constante ao redor de $40 \%$. O teor médio da matéria seca da planta (MS) ficou ao redor de $24 \%$. Assim, o aumento da população provocou pequeno decréscimo na qualidade da silagem.

A semeadura das áreas de produção deve ser realizada em função da perspectiva da colheita e em sincronismo com o ponto de colheita desejado. Em geral a planta de milho, dependendo do tipo de híbrido e das condições edafo-climáticas, apresenta um gradiente de maturação com velocidade variável, sustentam Nussio \& Manzano (1999).

\subsubsection{Composição e desenvolvimento da planta}

Schmid et al. (1976) reportam que foram analisadas 23 silagens de 11 híbridos de milho para determinar a importância da composição da planta e digestibilidade sobre o desempenho de carneiros. A porcentagem de grãos apresentou correlação positiva com a digestibilidade "in vivo" da matéria seca (MS), consumo de MS e ganho médio diário de

peso enquanto que outros componentes apresentaram correlações negativas. A porcentagem de grãos na matéria seca (MS) não apresentou correlação com a produção total.

Por outro lado, Hunter (1978) afirma que não existe forte relação entre qualidade da silagem e a participação de grãos na massa. De fato, até mesmo a completa falta de grãos na matéria colhida não implica em prejuízo para a alimentação do gado.

Pesquisando fatores que influenciam a qualidade da forragem conservada, Van Soest et al. (1978) concluíram que condições ambientais de crescimento determinam a composição da planta e seus limites de nutrientes. A temperatura, a qual aumenta a lignificação das paredes celulares é muito importante, enquanto que a maturação da planta e os efeitos da luz solar são secundários. Também, outros fatores, como disponibilidade de água, doenças e fertilidade afetam a qualidade da forragem, via 
desenvolvimento da planta. Entretanto, os autores salientam que quaisquer fatores que retardem a maturação da planta tendem a manter a qualidade do alimento.

Major \& Hamilton (1978) consideram como principais fatores climáticos envolvidos na produção de matéria seca do milho (MS) a temperatura, comprimento dos dias e disponibilidade de água. A temperatura do solo e do ar têm importância fundamental para o desenvolvimento e crescimento do milho, desde que ambas estejam situadas entre 10 e $30^{\circ} \mathrm{C}$. Além da germinação, a temperatura do solo influencia no número de folhas da planta madura e na terminação do crescimento.

O aumento do comprimento do dia atrasa o florescimento, sem afetar a taxa de crescimento da planta, entretanto o efeito mais visível do aumento é o número final de folhas e a altura potencial da planta, afirmam Major \& Hamilton (1978).

$O$ desenvolvimento da planta pode ser atrasado pelo déficit de água no solo por poucos dias, porém se esse fator de estresse perdurar por mais tempo, a produção de matéria seca pela planta poderá ser substancialmente reduzida. A falta de água no solo durante a fase de pendoamento pode causar falhas no crescimento e uma redução de desenvolvimento do pendão, mas não reduzirá a produtividade dos grãos. Todavia, se o estresse hídrico ocorrer durante a fase de enchimento dos grãos, a produtividade pode ser reduzida em 50\%, ainda salientam Major \& Hamilton (1978).

Daynard (1978) esclarece que, à medida que a planta de milho é colhida com um grau de imaturidade crescente, as maiores mudanças na composição envolvem a redução na proporção da matéria seca da planta em relação ao grão, e um aumento da taxa de umidade. Boas evidências garantem que a digestibilidade da matéria seca está mais relacionada com a concentração de lignina na forragem, e que as diferenças no conteúdo do grão apenas afetam a qualidade da alimentação do gado.

Quanto às características da silagem e seu grau de umidade, Daynard (1978) mostra que experimentos apresentaram reduções na ingestão de matéria seca de milho ensilado com baixa umidade, em relação à forragem colhida fresca. $\mathrm{O}$ decréscimo de ingestão foi atribuído por vários autores ao aumento das concentrações dos ácidos láctico e acético e/ou nitrogênio solúvel. Porém, quando as partículas foram cortadas em menor tamanho, houve um aumento de consumo dessa silagem de baixa umidade. 
Entretanto, Vilela (1983) considera que a qualidade e o valor nutritivo da silagem dependem fundamentalmente do estádio de maturação da planta no momento de corte e da natureza do processo fermentativo.

Pizarro (1978), relatando estudos sobre o crescimento e desenvolvimento da planta de milho, esclarece que o crescimento se completa entre 45 e 55 dias após a emergência das plântulas, sendo que durante os próximos 55 a 60 dias, a planta desenvolve os grãos. $O$ autor ressalva ainda que o crescimento das folhas e hastes termina entre 10 e 15 dias após a emergência dos estigmas.

Para que o aproveitamento da planta de milho seja pleno, Pizarro \& Andrade (1978) esclarecem que a colheita deve ser realizada no estágio de maturidade fisiológica. Neste ponto, pode-se obter a melhor combinação dos seguintes fatores: máximo rendimento de nutrientes digestíveis por hectare, mínimas perdas no campo e no armazenamento, máximo consumo por animal e máxima produção de matéria seca obtida por hectare.

White (1978) estudou o efeito da densidade populacional da cultura do milho a ser colhido para silagem. Concluiu que o aumento na densidade populacional deve ser reestudado se for aceita a hipótese de que a participação de grãos na planta não tem influência sobre o processo de produção de silagem. A produtividade e o teor de matéria seca (\%MS) na planta são os principais fatores para se avaliar produção e qualidade de silagem de milho.

Vários são os fatores ou práticas agrícolas que podem influenciar de maneira significativa a produção de milho para silagem, afirma Nussio (1991). O autor cita esses fatores e os valores que podem variar em função dos mesmos: variedades (0-3.138 $\mathrm{kg} / \mathrm{ha}$ ), população $(0-3.138 \mathrm{~kg} / \mathrm{ha})$, espaçamentos entre fileiras $(0-1.381 \mathrm{~kg} / \mathrm{ha})$, época de semeadura (43 kg/ha/dia após 04/01), controle de ervas daninhas $(0-1.381 \mathrm{~kg} / \mathrm{ha})$, irrigação (0-5.022 kg/ha), compactação $(0-1.067 \mathrm{~kg} / \mathrm{ha})$, rotação de culturas (0-1.067 $\mathrm{kg} / \mathrm{ha}), \mathrm{pH}(0-5.022 \mathrm{~kg} / \mathrm{ha})$ e perdas na colheita $(0-627 \mathrm{~kg} / \mathrm{ha})$.

Nussio (1991) afirma que, em vários estudos em universidades americanas, têmse mostrado que os híbridos precoces, em geral, apresentam maior teor de matéria seca na planta do que os híbridos normais, ao atingirem esse ponto de maturidade ideal dos 
grãos para ensilagem. Assim, a produção proveniente dos precoces tem melhores condições de garantir a qualidade, não só em função da maior proporção de grãos na matéria seca, mas também pelo maior teor de matéria seca do material quando cortado no momento da ensilagem, resultando em uma fermentação mais adequada.

Segundo Roth (1993), citado por Silva (1997), estresses ambientais no final da estação de desenvolvimento (enchimento dos grãos), causariam a translocação de carboidratos do colmo para os grãos, afetando negativamente a digestibilidade do colmo e a qualidade total da forragem. Similarmente, estresses no início da estação de crescimento, seguidos por boas condições de crescimento, pode resultar em menor rendimento de grãos, porém com maior qualidade na forragem.

Entretanto, Allen et al. (1997), citado por Silva (1997), observam que a qualidade de silagem é um termo complexo, e que somente fatores de qualidade que possuem repetibilidade das diferenças entre híbridos dever ser utilizados para seleção entre os mesmos. Estes autores também destacam o maior retorno financeiro oriundo de um híbrido de maior digestibilidade da fibra quando comparado a um híbrido de elevada produção de matéria seca (MS) por área.

Avaliando cultivares de milho para ensilagem, através da composição química e digestibilidade "in situ", Nussio (1997) afirma que parece ser claro que a qualidade do milho para silagem depende em parte da participação da espiga na planta, produção de grãos e porcentagem de grãos na matéria seca (MS).

Para Nussio \& Manzano (1999), a qualidade da silagem do milho geralmente é função da porcentagem de grãos na matéria seca do material ensilado, e da qualidade de colmos e folhas, principalmente colmos. Muitos hibridos de milho aumentam a participação de grãos na massa ensilada quando a maturidade avança.

A polêmica estabelecida entre a porcentagem de grãos na planta e a possível correlação com sua digestibilidade está em que a literatura disponibiliza grande amplitude de resultados sem tendência consistente. Sendo assim é possível localizar na literatura resultados erráticos, por vezes confirmando e em outras negando a relevância da presença da fração de grãos como condicionante do valor nutritivo da planta toda, sustentam Nussio \& Manzano (1999). 
Almeida Filho et al. (1999), apresentando dados das características agronômicas de vários cultivares de milho e qualidade de seus componentes e da silagem, ressaltam que híbridos da companhia Cargill (C-166 e C-435), apresentaram alturas de $1,81 \mathrm{~m}$, produtividades de $11.740 \mathrm{~kg} / \mathrm{ha}$, e espigas representando $37,12 \%$ do peso da planta.

\subsubsection{Ponto de colheita}

No estágio de maturidade fisiológica, o teor de matéria seca da planta inteira oscila entre 30 e $38 \%$. Neste momento, podem-se obter os máximos rendimentos, tanto para grãos quanto para matéria seca a ser ensilada, sustentam Pizarro \& Andrade (1978).

Pizarro \& Andrade (1978), ainda declaram que o ideal é começar a encher o silo quando o grão se encontra no estágio pastoso e duro. Isto pode acontecer entre 50 e 55 dias após a emergência dos estigmas. Para isso, um teste prático seria realizar a prova da "camada preta". Logo que os grãos atingem a maturidade fisiológica, muitas camadas de células perto da base do grão apresentam coloração mais escura. Para localizar a mesma, tira-se grãos do centro da espiga, cortando-os longitudinalmente ou descascando-lhes a ponta. Se aparecer a "camada preta", o grão encontra-se maduro, do ponto de vista fisiológico e pronto para ser ensilado.

O momento ideal de corte do milho, de acordo com Nussio (1991), ocorrerá quando as plantas apresentarem 33 a 37\% de matéria seca, o que será no ponto em que os grãos estiverem no estádio farináceo-duro, começando a apresentar a conformação dentada. As vantagens de se cortar a planta nesse período são:

a) decréscimo nas perdas no armazenamento, principalmente pela diminuição do efluente;

b) aumento significativo no consumo voluntário de silagem;

c) menor concentração total de ácidos durante a fermentação no silo e pH mais elevado.

Como possível desvantagem tem-se, provavelmente, um pequeno aumento nas perdas a campo e na colheita, principalmente pela maior perda de folhas (Nussio, 1991). 
Devido a um gradiente de maturação com velocidade variável que a planta de milho apresenta, existe uma "janela de colheita", ou seja, um período útil de trabalho para colheita da forragem dentro de um gradiente de maturidade desejável. Após o estádio de grãos leitosos, o material sofre aumento de $0,5 \%$ ao dia, no teor de matéria seca, determinando a necessidade de 10 dias, como intervalo adequado para a "janela de corte" na evolução de cinco unidades percentuais em matéria seca (30-35\%). Esse período compreende estádios fisiológicos de maturação da planta, cujos gradientes no teor de umidade da planta (70-65\%) e textura do grão (linha de leite a de $1 / 3$ à $2 / 3$ ) são considerados aceitáveis para a maximização da eficiência do processo fermentativo, reportam Nussio \& Manzano (1999).

Quanto ao porte da planta e dos cuidados da colheita do milho para silagem, Nussio (1998) esclarece que plantas com pequeno percentual de grãos podem ter outras partes de qualidade superior, o que acaba compensando na média. Existe uma correlação direta entre plantas de porte mais baixo com maior percentual de grãos, mas este aspecto não está descartado em plantas de porte médio, consideradas as mais adequadas a se ensilar. Estas apresentam alturas médias de 2,60 m no ponto de corte e a inserção das espigas em torno de $1,20 \mathrm{~m}$, o que garante menor efeito de pêndulo com a ação do vento.

\subsubsection{Corte e tamanho da partícula da planta de milho}

Para uma silagem de boa qualidade, a compactação da massa picada no silo deve ser contínua e intensa, a fim de obter alta densidade na massa ensilada. Além disso, a manutenção das facas afiadas da máquina picadora é condição ideal para a obtenção de partículas de tamanho entre 6,0 e $9,0 \mathrm{~mm}$, ideal para alcançar elevada densidade no silo (Nussio, 1991).

Um trabalho realizado com vacas leiteiras em produção, comparando silagens com tamanho de partículas entre 2,0 e $15,0 \mathrm{~cm}$, com teor de matéria seca entre $28-32 \%$, mostrou que o consumo, a conversão alimentar e a produção foram superiores com o menor tamanho. Já em estudos realizados na Austrália, destaca-se que o tamanho correto 
encontrado pelos pesquisadores para picagem seria entre 6,0 e $8,0 \mathrm{~mm}$, em que ocorreria maior digestibilidade da matéria seca e maior densidade no silo (Nussio, 1991).

Nussio (1998), também destaca a qualidade do corte da planta de milho no que se refere ao tamanho das partículas. $O$ ideal são partículas de tamanho médio de $1,0 \mathrm{~cm}$, reservando $20 \%$ do total com partículas de tamanho superior a $2,5 \mathrm{~cm}$. Com isso, o produto tem uma melhor estocagem, compactação adequada, ao mesmo tempo que o processo de digestão torna-se mais eficiente. Tal operação chega a aumentar a produção em 1 litro de leite/vaca/dia, já que o tratamento do alimento ajuda na digestão do amido e da fibra da planta.

Estudando as máquinas existentes para o corte de material volumoso, para a suplementação animal, Smith \& Wilkes (1979) salientam que a capacidade de corte de uma máquina ensiladora é influenciada pela superficie da abertura de entrada do material cortado, velocidade e taxa de alimentação e densidade do alimento. Quanto maiores estes parâmetros, maior é a capacidade de colheita da máquina. Porém, essa regulagem deve estar associada a sua própria capacidade interna, principalmente no que diz respeito à capacidade de corte e picagem do material, além da exigência em qualidade do alimento em relação ao tamanho da partícula cortada.

O tamanho da partícula cortada está relacionado com a variação da velocidade do trator, combinação das engrenagens de acionamento do mecanismo picador da máquina (o qual promoverá maior ou menor velocidade ao rotor) e número de facas no sistema picador, avalia Candelon (1971).

Compilando dados provenientes de folhetos promocionais de alguns fabricantes de máquinas ensiladoras no Brasil, Balsalobre et al. (1999) salientam que máquinas mais compactas possuem o mecanismo picador do tipo volante, sendo mais leves, enquanto que as máquinas, cujo mecanismo picador é do tipo tambor são maiores, porém nem por isso apresentam maior capacidade de colheita. Também, encontraram grande variação de capacidade de corte $(2,78$ a $13,89 \mathrm{~kg} / \mathrm{s})$, tamanho de partícula $(0,3$ a $2,2 \mathrm{~cm})$, potência exigida pela máquina (22,1 a 110,4 kW) e mecanismo picador (tambor de 6 a 16 facas, e volante de 6 a 12 facas). Tais dados reforçam a idéia de adequação da máquina ensiladora ao sistema produtivo da propriedade agrícola. 


\section{MATERIAL E MÉTODOS}

O experimento estava situado em terras pertencentes a Escola Superior de Agricultura "Luiz de Queiroz", da Universidade de São Paulo, localizada na cidade de Piracicaba (SP), com coordenadas geográficas $22^{\circ} 42^{\prime} 42^{\prime \prime} \mathrm{S}$ e $47^{\circ} 36^{\prime} 32^{\prime \prime} \mathrm{W}$.

A área de 66,47 ha $\left(664.700 \mathrm{~m}^{2}\right)$, sob responsabilidade do Departamento de Produção Animal (LPA), é utilizada para produção de milho (Zea mays L.) e forragem. O solo foi classificado como Terra Roxa Estruturada (TE), de textura argilosa. O experimento foi instalado na área em duas parcelas contíguas de $11.250 \mathrm{~m}^{2}$.

\subsection{MATERIAL}

O material utilizado no experimento refere-se aos equipamentos agrícolas e aos dispositivos para mensuração.

\subsubsection{Tratores}

Os tratores utilizados no experimento foram os da marca Valtra/Valmet, $885 \mathrm{~S}$, $4 \times 2$ com $62 \mathrm{~kW}$ de potência, e Massey Ferguson, modelos 275 4x2 TDA e 296 4x2, com 55,2 e $88 \mathrm{~kW}$ de potência, respectivamente.

\subsubsection{Máquinas e implementos}

$\mathrm{Na}$ operação de preparo do solo, foi utilizado um escarificador de marca Stara, de 5 hastes, espaçadas a $30,0 \mathrm{~cm}$ e duas grades, uma niveladora $(32$ discos de $51,0 \mathrm{~cm}$ de 
diâmetro) e outra média (14 discos de $64,0 \mathrm{~cm}$ de diâmetro), de marca Baldan, com discos espaçados a $20,0 \mathrm{~cm}$ e 45,0 cm, e pesos totais de $690 \mathrm{~kg}$ (peso por disco de 21,56 $\mathrm{kg}$ ) e $2.632 \mathrm{~kg}$ (peso por disco de $188 \mathrm{~kg}$ ), respectivamente, de acordo com a classificação de Gadanha Junior et al. (1991).

Na semeadura, foi utilizada uma semeadora da marca Semeato, modelo PSU-8, de 4 unidades ("carrinhos") equipadas com discos de sementes de 24 furos. As unidades foram denominadas de $1,2,3$, e 4, considerando-se como referência a máquina sendo observada pela sua parte traseira, da esquerda para a direita no sentido de deslocamento do trator. Na colheita, foi utilizada uma colhedora de forragens de marca Nogueira, modelo Pecus 9004 de 1 linha.

\subsubsection{Análise das características de preparo do solo}

\subsubsection{Profundidade de preparo}

Para a avaliação da profundidade de escarificação, foi utilizado um penetrômetro hidráulico (medidor de resistência de solos), de marca Dickey-john, com haste de $0,95 \mathrm{~m}$ (Figura 3).

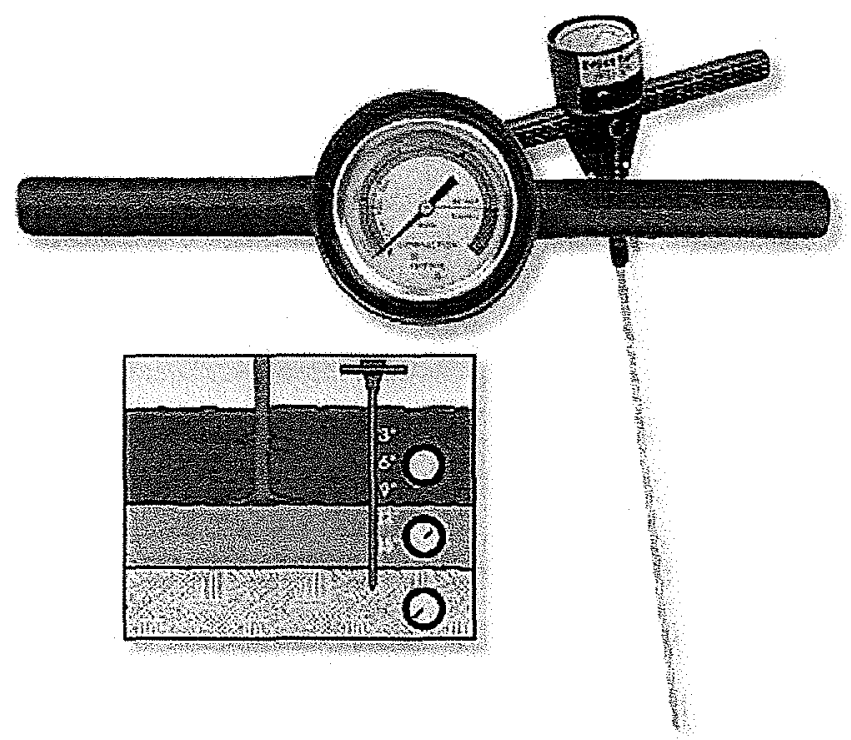

Figura 3 - Modelo do penetrômetro hidráulico utilizado no experimento. 
$\mathrm{O}$ aparelho em questão, indica valores numéricos em um manômetro, com valores na faixa de restrição de 1,37 a 5,24 $\mathrm{MPa}$ (além de uma escala em cores), conforme a resistência imposta pelo solo à penetração de sua haste. A ponta utilizada para a avaliação foi a de 1/2" $(1,27 \mathrm{~cm})$ de diâmetro.

\subsubsection{Tamanho de torrão}

Foi construído um dispositivo para avaliação de tamanho de torrão, no formato de um quadrado de $0,71 \mathrm{~m}$ de lado com outros 3 quadrados menores soldados no vértices interiores, com lados de $4,0 \mathrm{~cm}, 7,0 \mathrm{~cm}$ e $9,0 \mathrm{~cm}$, respectivamente, em vergalhão metálico de $7,0 \mathrm{~mm}$ de diâmetro.

Os quadrados foram pintados em diferentes cores, sendo que o verde tem a dimensão da classe de tamanho de torrões desejáveis para a operação em questão, o quadrado amarelo tem a dimensão de $7,0 \mathrm{~cm}$, que corresponde a torrões de tamanho médio, e o quadrado vermelho corresponde a torrões de tamanho maiores que $9,0 \mathrm{~cm}$, muito grandes para o padrão da área (Figura 4).

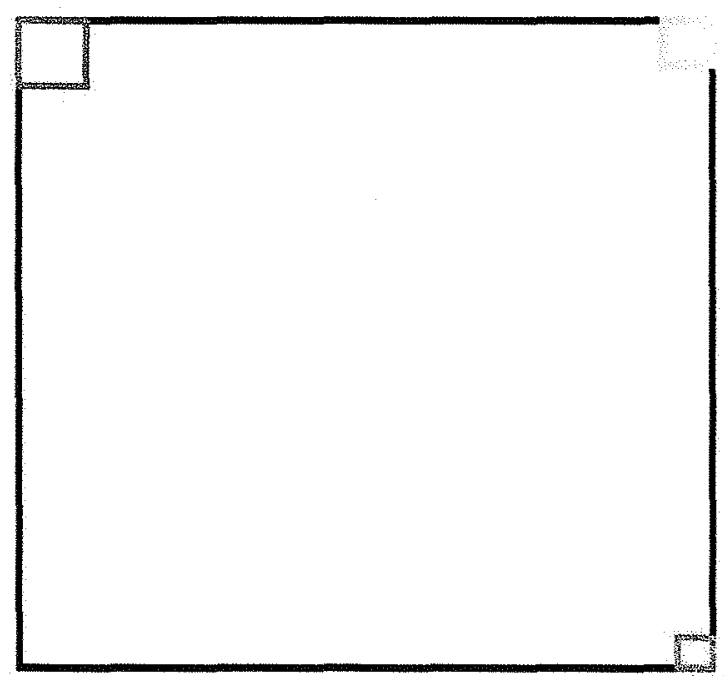

Figura 4 - Esquema do dispositivo criado para a medição do tamanho dos torrões nas áreas analisadas. 
Cabe aqui salientar que o dispositivo em questão foi criado empiricamente, sem embasamento científico. A falta de um dispositivo que permitisse avaliar de alguma forma a proporção de torrões em uma determinada área conhecida, que ao mesmo tempo fosse transportável e de fácil entendimento e operação pelos pessoal de campo foram os principais motivos que motivaram a criação e desenvolvimento do mesmo.

\subsubsection{Análise das características da cultura}

$\mathrm{Na}$ avaliação do espaçamento entre plantas, o material utilizado foi uma fita métrica (trena) de 5,0 m de comprimento, com graduação em milímetros (mm) e estacas de madeira para marcação do terreno. Os dados provenientes da leitura eram anotados e passados para uma planilha para futuros cálculos.

As leituras de altura das plantas de milho eram realizadas com o auxilio de uma fita métrica (trena), de comprimento total de $5,0 \mathrm{~m}$, e graduação em milímetros $(\mathrm{mm})$, além de estacas de madeira para marcação do terreno.

\subsubsection{Colheita}

Com o intuito de se analisar a participação em peso das estruturas da planta e o tamanho da partícula picada, utilizou-se uma balança eletrônica de marca Filizola, modelo MF-3, com capacidade máxima de $3,0 \mathrm{~kg}$, e escala de $5,0 \mathrm{~g}$, de modo a calcular a densidade linear de colmos e a avaliação das partículas de milho. Além disso, para a avaliação das partículas, utilizou-se uma jarra de volume igual a 1,8 L, para coleta do material na carreta, uma caixa de isopor e sacos plásticos, para acondicionamento do material no campo, e um conjunto de peneiras (a superior com furos de 1,9 cm, a intermediária com furos de $0,78 \mathrm{~cm}$, e uma inferior, sem furos) desenvolvidas por pesquisadores da Universidade da Pensilvânia (Pennsylvania State University), nos Estados Unidos da América. 


\subsection{MÉTodos}

\subsubsection{Instalação das parcelas}

Escolheu-se na área, em comum acordo com o corpo técnico do Departamento de Produção Animal (LPA), um talhão para serem instaladas as parcelas experimentais, em número de duas. A primeira denominada de $\mathrm{Al}$ refere-se à parcela onde a operação foi avaliada após a mesma. A segunda, denominada A2, foi aquela onde o controle da operação foi realizado durante a execução. Cada parcela media $225 \mathrm{~m}$ por $25 \mathrm{~m}$, totalizando $5.625 \mathrm{~m}^{2}$. Entre elas, foi deixada uma faixa de $20 \mathrm{~m}$ de comprimento para as manobras e paradas do conjunto mecanizado. A área total do experimento foi de 11.750 $\mathrm{m} 2$, considerando-se a área para manobras.

As duas parcelas foram demarcadas com estacas de modo a formar uma malha de 75 células, distribuídas em 15 colunas e 5 linhas (Figura 5). Cada célula teve $15 \mathrm{~m}$ de comprimento e $5 \mathrm{~m}$ de largura. Essa metodologia teve como base os trabalhos de Peche Filho et al. (1994) e Fernandes (1997).

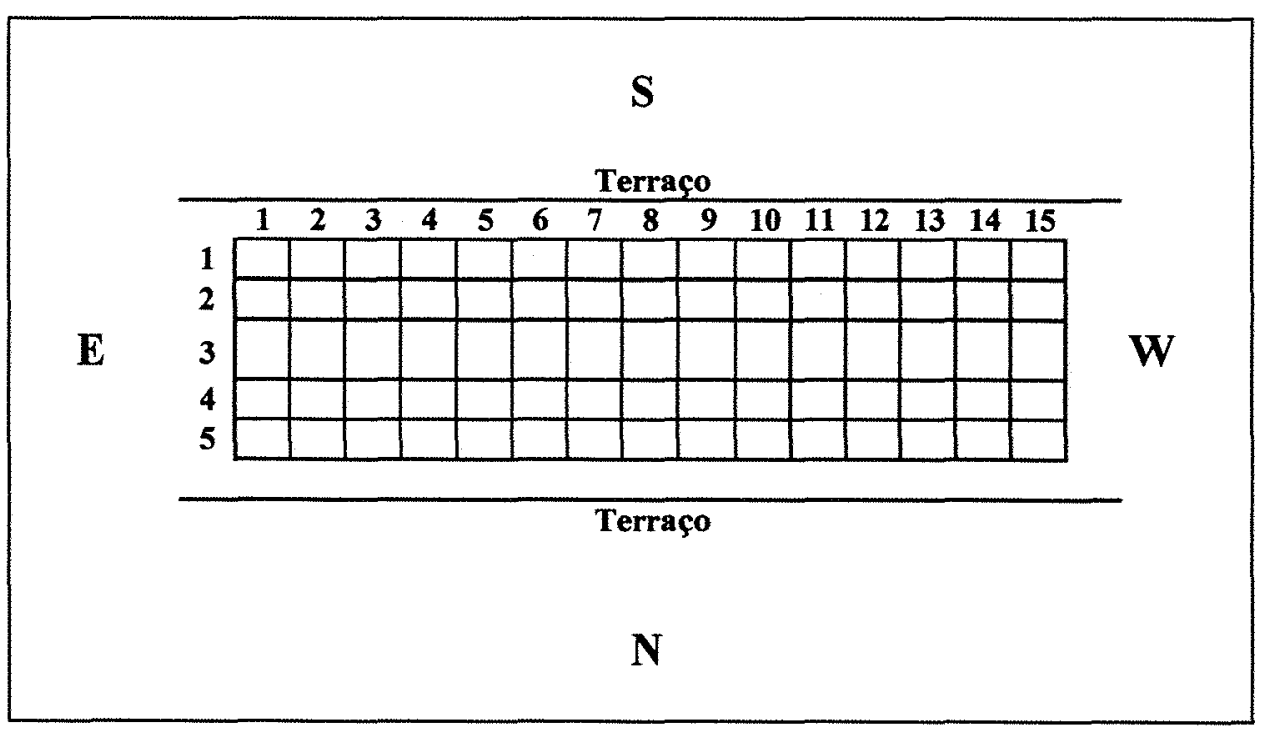

Figura 5 - Modelo da malha aplicada aos talhões analisados no experimento. 


\subsubsection{Procedimento operacional e análise dos valores}

Com a finalidade de se avaliar e mensurar a qualidade de trabalho realizado foram criados, parâmetros (indicadores) para as operações mecanizadas e atribuídos padrões (valores numéricos) desejáveis para atender as necessidades da cultura, de acordo com o corpo técnico do departamento. Os indicadores são apresentados no Quadro 6.

Quadro 6. As operações mecanizadas avaliadas, seus parâmetros e limites de especificação.

\begin{tabular}{|c|c|c|}
\hline Operação & Parâmetros & Limites \\
\hline Escarificação & - Profundidade de trabalho $(\mathrm{m})^{*}$ & - $\quad 0,20$ a $0,25 \mathrm{~m}$ \\
\hline Gradagem & - Diâmetro de torrão (m) & - $\quad 0,0$ a $0,04 \mathrm{~m}$ \\
\hline Semeadura & - Espaçamento entre plantas (m) & - $\quad 0,20$ a $0,25 \mathrm{~m}$ \\
\hline \multirow[t]{3}{*}{ Colheita } & - Produção de massa (kg MS/m) & - n.d. \\
\hline & - Relação espiga/planta, folhas/planta (\%) & - n.d. \\
\hline & - Tamanho de partícula (m) & - $0,01 \mathrm{~m}^{* *}$ \\
\hline
\end{tabular}

(*) $m=$ metro; $\mathrm{kg} M S / m$ = quilograma de matéria seca por metro de sulco; $n . d .=$ dado não disponível (não padronizado).

(**) Como a variabilidade de tamanho de partícula dentro da amostra é grande, deseja-se que a maior parte das partículas esteja com tamanho próximo a $0,01 \mathrm{~m}$.

Para as operações de escarificação e gradagem, o procedimento operacional adotado foi dividido em duas partes. $\mathrm{Na}$ área $\mathrm{A} 1$, o operador realizou as operações de acordo com a rotina de trabalho do LPA. Foram fornecidas a ele as instruções básicas quanto aos indicadores e a operação executada. Já para a área A2, foram fornecidas as instruções ao operador sobre a importância da qualidade do serviço a ser realizado, os valores desejados para o indicador e durante a operação foram feitas verificações dos valores e, se necessário, ajustes foram efetuados nos equipamentos. 
Para as operações de semeadura e colheita, a coleta de dados foi realizada após a operação, para permitir o acompanhamento do desenvolvimento e a resposta da cultura de milho quanto à realização ou não do controle da qualidade nas operações antecedentes de preparo do solo.

A análise dos dados foi efetuada com base nas ferramentas estatísticas aplicadas ao controle de qualidade: gráfico de controle de médias e amplitudes, histogramas de distribuição e gráficos de correlação, de acordo com a metodologia proposta por Kume (1993) e Vieira (1999). As diferenças estatísticas entre as médias apresentadas foram obtidas através dos testes T e Tukey e ANOVA, ao nível de significância de 5\%.

\subsubsection{Avaliação dos parâmetros}

\subsubsection{Profundidade de trabalho}

A escarificação nas duas áreas de tratamento foi realizada no dia 18 de dezembro de 1999. O trator utilizado foi o Massey Ferguson 296 acoplado ao escarificador, regulado para operar a $25,0 \mathrm{~cm}$ de profundidade.

A profundidade de trabalho foi determinada para a operação agrícola de escarificação. $\mathrm{O}$ indicador "profundidade de trabalho" foi medido em metros (m).

O objetivo desta avaliação foi analisar a uniformidade do trabalho realizado na área de produção de milho, com a visão de se obter valores entre 0,20 e $25,0 \mathrm{~cm}$ de profundidade, considerada ideal pelos responsáveis técnicos para a cultura do milho.

A medição foi realizada em cada um dos 75 pontos marcados (na malha) nas áreas analisadas no experimento, coletando-se dois valores: uma na linha da haste e outro no espaço entre as hastes. A amostragem foi realizada seguindo-se o sentido lesteoeste do talhão, partindo-se do ponto 1 até o 15 , do 16 ao 30 , e assim por diante até que fosse amostrado o ponto 75. Para tal, foi utilizado um penetrômetro hidráulico já descrito anteriormente.

Conforme a penetração da haste do aparelho no solo, o manômetro fornecia uma indicação da pressão de resistência sofrida pela ponta da haste. Quando este valor no 
manômetro atingia $1,37 \mathrm{MPa}$, era encontrada a resistência no solo limitante ao crescimento de raízes.

De posse dos valores de profundidade obtidos pelo uso do penetrômetro, foram construídos histogramas de distribuição e cartas de controle de médias e amplitudes.

Com os dados amostrados na área $\mathrm{Al}$, foram sugeridas e realizadas mudanças no modo de trabalho no campo antes do início na área A2. As melhorias realizadas na operação de escarificação, após o trabalho na área A1 e antes do início na A2 foram:

1) Alinhamento dos discos cortadores de palha do implemento, os quais estavam desalinhados com as hastes do escarificador;

2) Ajuste e checagem constante da profundidade durante a operação;

3) Mudança de marcha de trabalho do trator, reduzindo a velocidade, melhorando a penetração do implemento na solo.

\subsubsection{Diâmetro de torrão}

A gradagem nas duas áreas de tratamento foi realizada no dia 27 de dezembro de 1999. Foram realizadas, ao total, duas operações, uma com grade média e outra (em seguida) niveladora com os tratores Valtra/Valmet $885 \mathrm{~S}$ e Massey Ferguson 275. A velocidade efetiva (real) de trabalho foi $1,18 \mathrm{~m} / \mathrm{s}(4,27 \mathrm{~km} / \mathrm{h})$ e $1,04 \mathrm{~m} / \mathrm{s}(3,74 \mathrm{~km} / \mathrm{h})$, para as grades leve e pesada, respectivamente, na área A1. E a velocidade real para as grades leve e pesada na área $A 2$, foram $1,48 \mathrm{~m} / \mathrm{s}(5,31 \mathrm{~km} / \mathrm{h})$ e $1,34 \mathrm{~m} / \mathrm{s}(4,82 \mathrm{~km} / \mathrm{h})$, respectivamente.

O tamanho de torrão foi checado na operação agrícola de gradagem e seu indicador "profundidade de trabalho" foi medido em metros (m).

O objetivo desta checagem foi analisar a uniformidade do trabalho realizado pelas grades, com a visão de se obter valores sempre menores que $4,0 \mathrm{~cm}$ de diâmetro, considerada ideal para a cultura do milho.

A medição foi realizada em cada ponto da mesma maneira que durante a da escarificação. Em cada ponto da malha, após a passagem das duas grades, o quadrado era jogado ao acaso no solo e os agregados eram medidos dentro do dispositivo. Foram 
definidas cinco classes de tamanho de torrões: menor que $0,04 \mathrm{~m}$, de $0,04 \mathrm{~m}$ até 0,055 $\mathrm{m}$, de $0,055 \mathrm{~m}$ até $0,07 \mathrm{~m}$, de $0,07 \mathrm{~m}$ até $0,08 \mathrm{~m}$, e $0,08 \mathrm{~m}$ até $0,09 \mathrm{~m}$. Conforme a proporção de torrões dentro do dispositivo, o anotador julgou visualmente a classe encontrada, mediante os parâmetros pré-fixados nos vértices do mesmo. As classes intermediárias eram julgadas caso houvesse um empate na proporção dentre duas classes de tamanho dos torrões.

Anteriormente ao início da operação de gradagem na área $\mathrm{A} 2$, foram sugeridas $\mathrm{e}$ realizadas mudanças no modo de trabalho no campo após uma conferência dos dados coletados na área A1 (sem CEP). As melhorias sugeridas e realizadas para a operação de gradagem foram:

1) Limpeza dos discos das grades, retirando-se a terra alojada entre os mesmos;

2) Aperto dos parafusos dos mancais e da barra porta-ferramentas das grades;

3) Alteração da velocidade de trabalho (troca de marcha dos tratores).

\subsubsection{Espaçamento entre plantas}

A semeadura nas duas áreas de tratamento foi realizada no dia 27 de dezembro de 1999, com o trator Massey Ferguson 275 acoplado à semeadora.

O indicador avaliado na operação agrícola de semeadura foi o espaçamento entre plantas, medido em metros (m), cujo padrão desejado foi de 0,20 a $0,25 \mathrm{~m}$ entre plantas, considerada ideal para a cultura do milho, para silagem. Esse parâmetro foi escolhido com o intuito de proporcionar a menor interferência à operação de semeadura, realizada sem paradas ou ajustes.

O controle foi feito através de avaliações em cada área, obtendo-se o espaçamento entre plantas nas linhas, na distância correspondente $1,0 \mathrm{~m}$ de sulco. Os locais de amostragem foram determinados aleatoriamente, obtendo-se 250 pontos em cada linha de semeadura correspondente a cada unidade de semeadura. A análise e apresentação dos dados foi feita conforme sugerido pela ABNT (1985) e Coelho (1996).

Os tipos de espaçamentos descritos aqui são duplos, normais e falhas. Os duplos são todos os espaçamentos menores que a metade $(0,5)$ do espaçamento de referência 
(Xref); os normais estão entre a metade $(0,5)$ e uma vez e meia $(1,5)$ do Xref, e as falhas são os espaçamentos maiores que uma vez e meia $(1,5)$ o Xref (Coelho, 1996). Como espaçamento referência foi considerado o de $0,25 \mathrm{~m}$ entre plantas.

\subsubsection{Altura de plantas}

O desenvolvimento vegetativo das plantas (altura), em ambos os tratamentos foi monitorado a cada 7 dias, de 29 de janeiro de 2000, verificando-se uniformidade de germinação, até 4 de março de 2000 , semana do início do florescimento e término do crescimento vegetativo das plantas. A resposta da cultura aos 2 tratamentos foi registrada em termos de altura média das plantas nos diferentes estádios de crescimento (com amostragens semanais).

\subsubsection{Colheita}

a) Produção de massa

No dia 12 de abril de 2000 , dois dias antes do início da colheita do milho para o processo de ensilagem, foram coletadas várias plantas ao longo da área experimental, com a finalidade de se avaliar a produção de massa $(\mathrm{kg} \mathrm{MS} / \mathrm{m})$ apresentada pela lavoura de milho.

A coleta consistiu em se cortar e enfeixar as plantas localizadas em 2 metros lineares, escolhidas ao acaso. Para cada linha semeada, dentro das duas sub-áreas analisadas, coletou-se 6 feixes de plantas, perfazendo um total de 48 conjuntos. As plantas enfeixadas foram separadas e cortadas conforme suas estruturas (haste, folhas, espiga e palha), pesadas em balança eletrônica para determinação da parte aérea da planta. 


\section{b) Corte da planta}

A colheita para a ensilagem foi realizada nos dias 14 e 15 de abril de 2000. Toda a área foi colhida pelo mesmo operador com o mesmo conjunto mecanizado, composto do trator e colhedora de forragens.

O conjunto mecanizado foi abastecido, lubrificado e regulado conforme as especificações dos fabricantes na manhã do dia 14 , sendo que essa foi a única interferência ocorrida nos ajustes do processo.

As duas parcelas foram consideradas como uma só, já que o foco da qualidade foi de se avaliar a qualidade do material picado pela máquina, não mais o material no campo. Desse modo, o operador iniciou o corte das plantas de milho utilizando o percurso denominado "fechando o quadrado".

\section{c) Avaliação das partículas de forragem}

Ao início do corte na área, foi tomada uma amostra do material picado, de volume equivalente a $1,8 \mathrm{~L}$, que seria tomada como o referencial da máquina antes do desgaste natural dos mecanismos de corte durante a operação de colheita. Esta amostra foi chamada de Al.

A cada 30 minutos de trabalho efetivo da máquina colhedora, era coletada uma amostra e acondicionada em um isopor com gelo para posterior análise de laboratório. Ao total, foram coletadas 21 amostras, correspondendo a 10 horas de trabalho real da máquina. Essas amostras foram pesadas e peneiradas para a classificação de tamanho de partículas resultantes do corte.

No laboratório, aproximadamente uma fração de $0,4 \mathrm{~kg}$ de cada uma das 21 amostras eram separadas, pesadas e passadas por um conjunto de peneiras. A fração retida em cada uma das peneiras era pesada e colocada em uma proveta com capacidade máxima de $0,9 \mathrm{~L}$ e graduação de $10 \mathrm{~mL}$, para uma posterior correlação entre peso e volume da silagem produzida, densidade original e densidade medida nas peneiras; e umidade das amostras e peso retido nas peneiras. A metodologia de uso, manipulação 
das peneiras e análise dos dados obtidos foi seguida segundo Heinrichs (1996) e Lammers et al. (1996).

Após a pesagem e medição de volume, as 21 amostras foram acondicionadas e armazenadas em uma estufa, por 48 horas, a $60^{\circ} \mathrm{C}$, para a determinação do peso seco de cada uma delas. A pesagem deste material foi realizada na balança descrita anteriormente.

De posse dos dados de laboratório, plotou-se os mesmos no papel de distribuição de Weibull, para extrapolação dos tamanhos e proporções das partículas cortadas na operação, avaliando assim a qualidade do material picado.

Assim, pôde-se determinar a umidade de cada amostra e seu respectivo peso seco. A finalidade deste experimento foi de amostrar e conferir o desgaste da máquina em função do tempo de operação, com base no tamanho das partículas da planta de milho.

Outra finalidade foi detectar a existência de relação entre peso, densidade original, densidade do material picado, umidade e volume do material picado em alguma etapa do processo de separação nas peneiras. Esses estudos de correlação tiveram como intuito criar um dispositivo mais prático de campo (alternativo às peneiras de laboratório) para a medição de tamanho de partícula e medição da qualidade da mesma.

A viabilidade do emprego desse sistema em operações agrícolas foi analisada pelo desenvolvimento da cultura no campo, pela qualidade da silagem produzida e pela possibilidade da identificação de problemas e possíveis soluções aos mesmos, devido ao monitoramento contínuo. 


\section{RESULTADOS E DISCUSSÃO}

\subsection{OPERAÇÃo de ESCARIFICAÇÃo}

$\mathrm{Na}$ Figura 7, são apresentados os resultados referentes à operação de escarificação para a área A1. A amplitude da profundidade variou de 0,1 a $0,4 \mathrm{~m}$ e a maior ocorrência encontrada foi a profundidade de $0,20 \mathrm{~m}$, enquanto que a recomendação (padrão) da operação era que a mesma fosse efetuada entre 0,20 e 0,25 m. Os dados aceitáveis dentro da área resultaram em $34,0 \%$ do total apresentado. A área A2 (Figura 8) revela uma diminuição da amplitude, a qual variou de 0,15 a $0,325 \mathrm{~m}$, com concentração de pontos em $0,20 \mathrm{~m}$. Pela comparação dos histogramas, observou-se que as modificações efetuadas causaram uma concentração maior dos dados ao redor do valor desejado com $55,9 \%$ da frequência relativa, dentro do intervalo delimitado pelos limites de especificação.

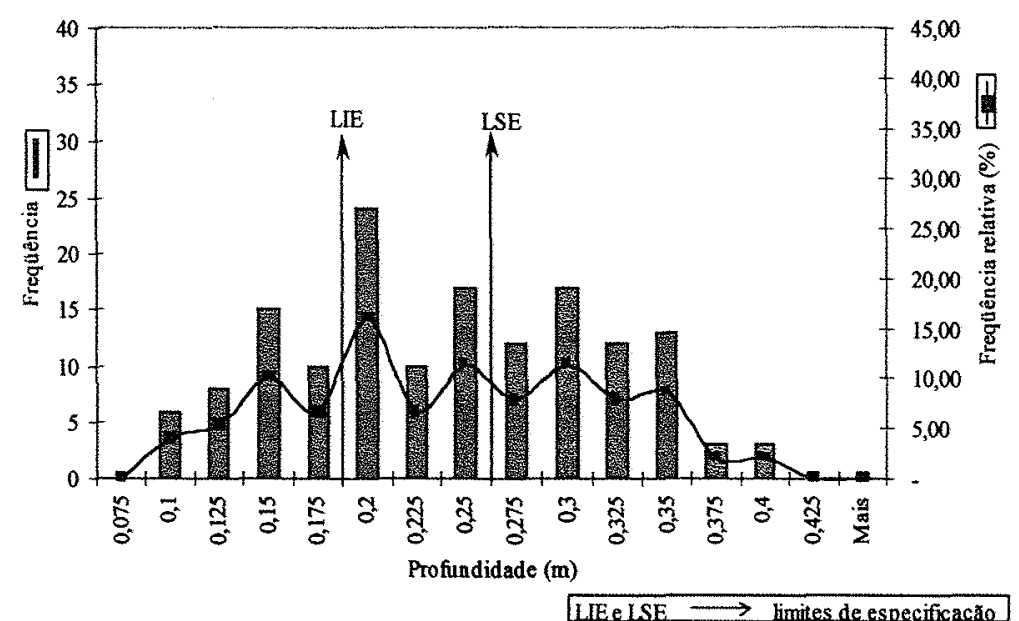

Figura 7 - Histograma de distribuição da profundidade de escarificação, na área A1. 


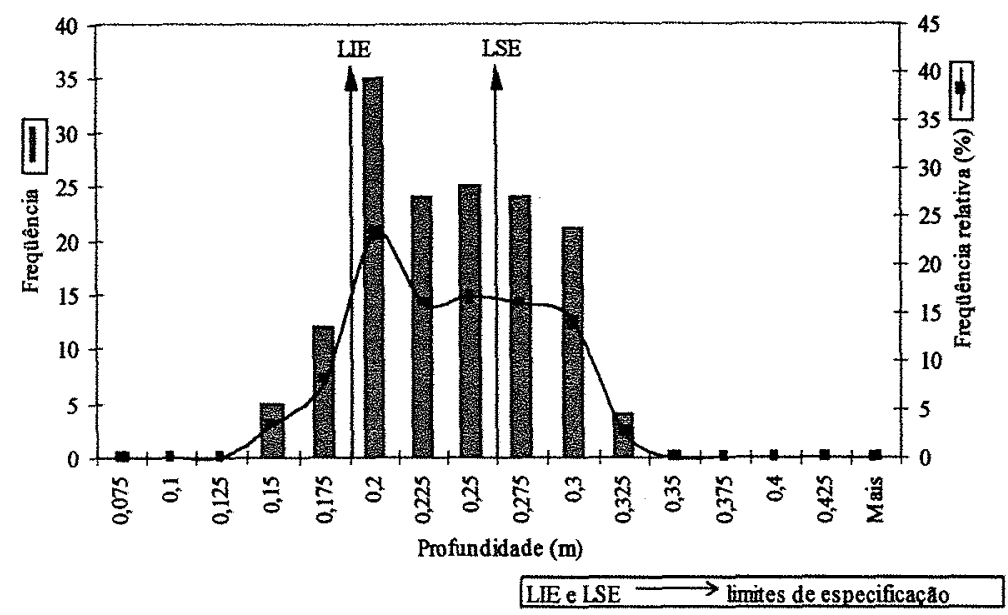

Figura 8 - Histograma de distribuição da profundidade de escarificação, na área A2.

Com a adoção do controle, houve um redução de $38,4 \%$ na variabilidade dos dados (número de classes), e um aumento de $45,0 \%$ no número de pontos amostrados com valores $0,25 \mathrm{~m}$.

Analisando-se a carta de controle com médias para a área $\mathrm{A} 1$, verifica-se que a média encontrada foi de $0,23 \mathrm{~m}$ para os pontos amostrados, e do total de 15 grupos, os quais variaram de 0,19 a $0,26 \mathrm{~m}, 4$ estão fora dos padrões especificados para a operação. Apesar disso, o processo encontrou-se dentro de controle (Figura 9). Na área A2 (Figura 10), observou-se que a variação dos dados foi menor, indo de 0,21 a $0,25 \mathrm{~m}$, com média de 0,23 m também; além disso, nenhum grupo de pontos encontrou-se fora dos limites de especificação escolhidos pelo corpo técnico.

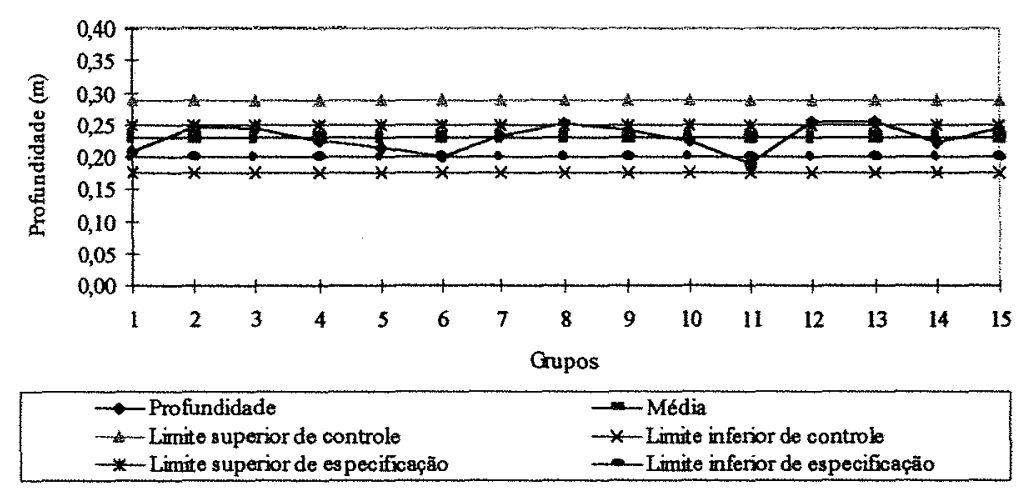

Figura 9 - Carta de controle com médias, para a operação de escarificação, na área A1. 


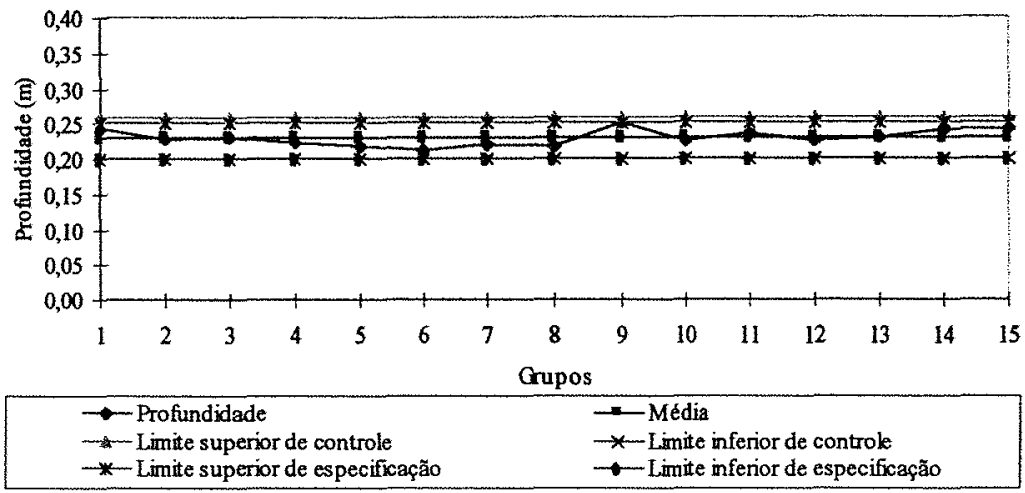

Figura 10 - Carta de controle com médias, para a operação de escarificação, na área A2.

Avaliando-se a amplitude dos dados, as diferenças são ainda notadas. Na área $\mathrm{A} 1$, a média das amplitudes foi de $0,10 \mathrm{~m}$ entre os grupos, enquanto que na área $\mathrm{A} 2$, esse valor foi de $0,05 \mathrm{~m}$, ou seja, houve uma redução de $50 \%$ na amplitude dos dados com a implantação do CEP (Figuras 11 e 12).

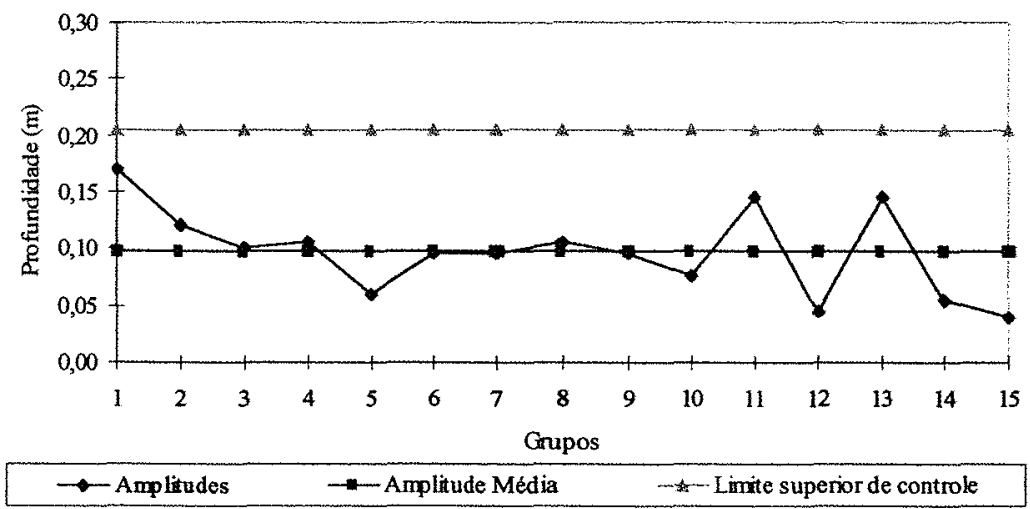

Figura 11 - Carta de controle com amplitudes, para a operação de escarificação, na área A1. 


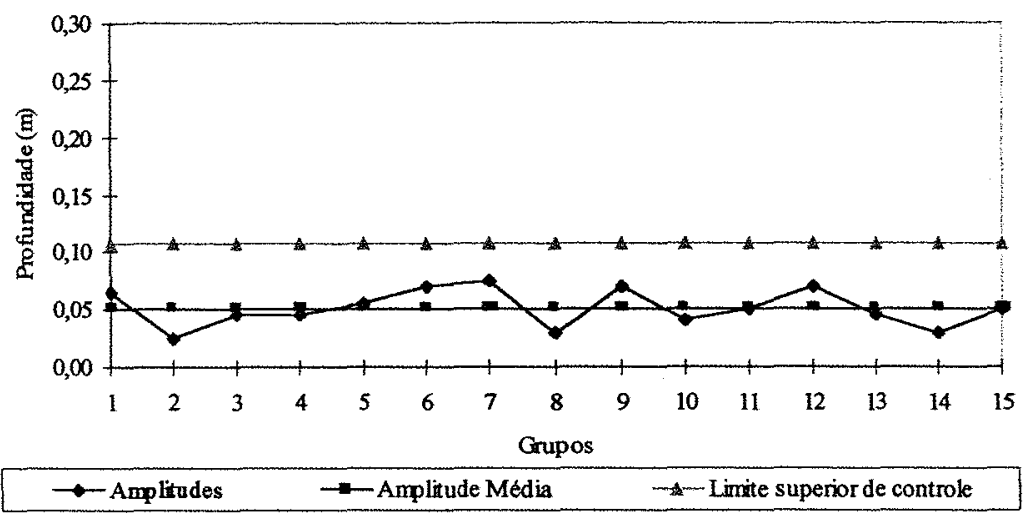

Figura 12 - Carta de controle com amplitudes, para a operação de escarificação, na área A2.

Entretanto, a comparação de médias das áreas, realizada através do teste $\mathrm{T}$, revela que as parcelas não diferem estatisticamente, não comprovando as informações. Cabe salientar que os dados considerados são valores médios entre a profundidade medida na direção da haste do escarificador e a medida entre as hastes (Tabela 1).

Tabela 1. Análise estatística (teste T) para os dados da operação de escarificação.

\begin{tabular}{lcccc}
\hline Tratamento & Média (m) & Desv. Padr. & Prob $>|\mathrm{T}|$ & \\
\hline Sem CEP & 0,229 & 0,0761 & 0,0001 & A \\
Com CEP & 0,229 & 0,0464 & 0,0001 & A
\end{tabular}

Tratamentos com letras distintas são diferentes estatisticamente, ao nível de significância de $5 \%$

A análise dos histogramas revelou, porém, que a distribuição dos dados ocorreu de forma multi-modal na área A1 e bi-modal na A2. Onde a haste do implemento atuou obteve-se uma maior profundidade quando comparado à atuação no espaço entre as hastes no solo, onde a mobilização foi realizada pelo efeito de interferência, razão pela qual optou-se também por avaliar as duas situações independentemente. Para confirmar a segregação de dados visualizada nos histogramas, uma análise estatística (teste $T$ ) foi utilizada para analisar os dados provenientes das medições de profundidade na linha de 
preparo e na entrelinha, comprovando que existe diferença estatística entre esses dois grupos medidos, tanto na área A1 como na A2 (Tabela 2).

Tabela 2. Análise estatística (teste T) para os dados coletados na linha de preparo do solo e na entrelinha, na operação de escarificação.

\begin{tabular}{llrrrr}
\hline & Medição & Média $(\mathrm{m})$ & Desv. Padr. & Prob $>|\mathrm{T}|$ & \\
\hline \multirow{2}{*}{ A1 } & Linha & 0,288 & 0,0511 & 0,0001 & A \\
& Entrelinha & 0,172 & 0,0471 & 0,0001 & B \\
\multirow{2}{*}{ A2 } & Linha & 0,261 & 0,0289 & 0,0001 & A \\
& Entrelinha & 0,197 & 0,0278 & 0,0001 & B \\
\hline
\end{tabular}

Tratamentos com letras distintas são diferentes estatisticamente, ao nível de significância de 5\%

\subsubsection{Linha de preparo do solo}

Para a área A1, verifica-se que a média encontrada foi de $0,29 \mathrm{~m}$ para os pontos amostrados e, do total de 15 grupos, os quais variaram de 0,24 a $0,32 \mathrm{~m}$, apenas 2 estão dentro dos padrões especificados para a operação. Apesar disso, o processo encontrou-se dentro de controle (Figura 13). Na área A2 (Figura 14), observou-se que a variação dos dados foi menor, entre 0,24 a $0,28 \mathrm{~m}$, com média de $0,26 \mathrm{~m}$; entretanto ainda 3 grupos de pontos encontraram-se fora dos limites de especificação escolhidos pelo corpo técnico.

Assim, a implantação do CEP, apesar de não satisfazer os padrões desejados, trouxe a médias dos dados mais próxima do limite superior, reduzindo-a em 10,3\%.

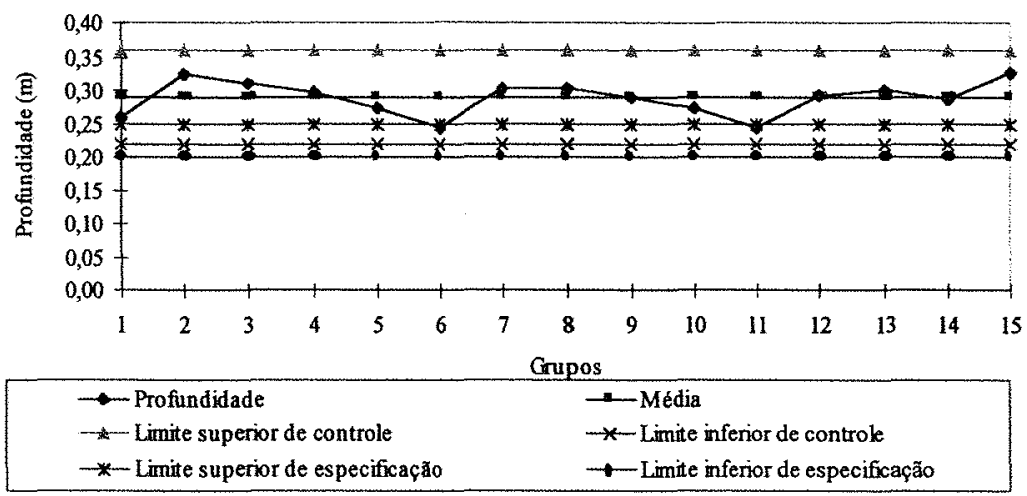

Figura 13 - Carta de controle com médias, para a operação de escarificação na linha de preparo, na área A1. 


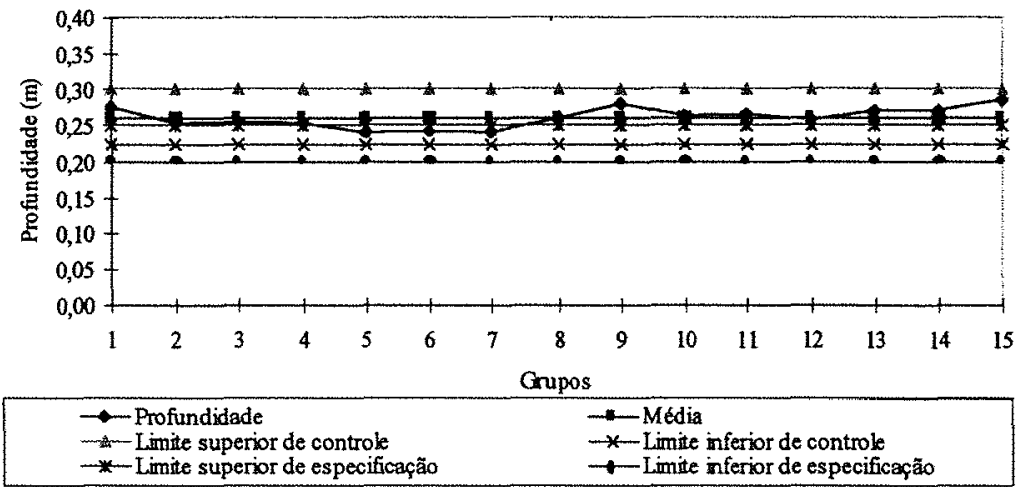

Figura 14 - Carta de controle com médias, para a operação de escarificação na linha de preparo, na área A2.

Ainda analisando a linha de preparo da escarificação, constatou-se que na área A1, a média encontrada de amplitudes entre os grupos foi de $0,12 \mathrm{~m}$, com controle superior de 0,30 m (Figura 15). Já para a área A2 (Figura 16), visualizou-se uma menor variação de valores, com média atingida de $0,067 \mathrm{~m}$. Desse modo, a introdução do CEP resultou em uma redução média da amplitude dos dados dentre os grupos de 44,2\%.

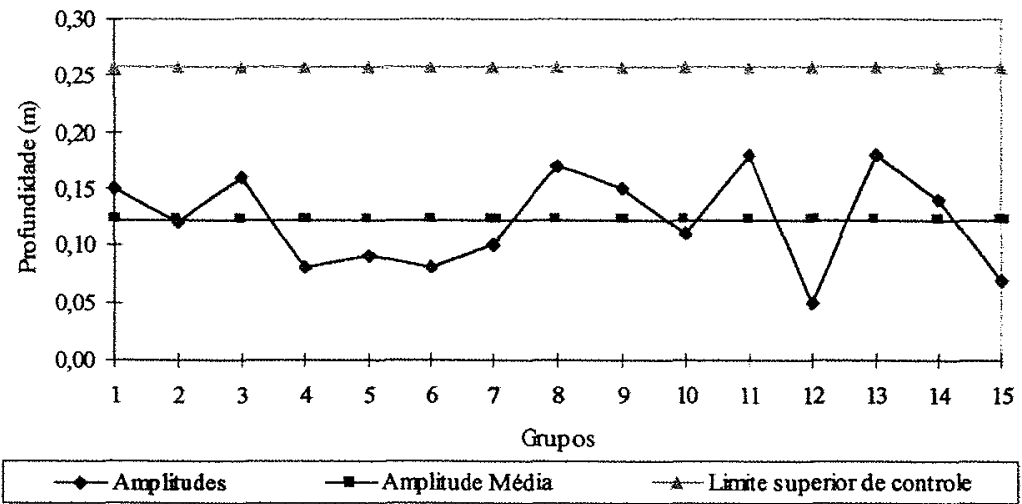

Figura 15 - Carta de controle com amplitudes, para a operação de escarificação na linha de preparo, na área A1. 


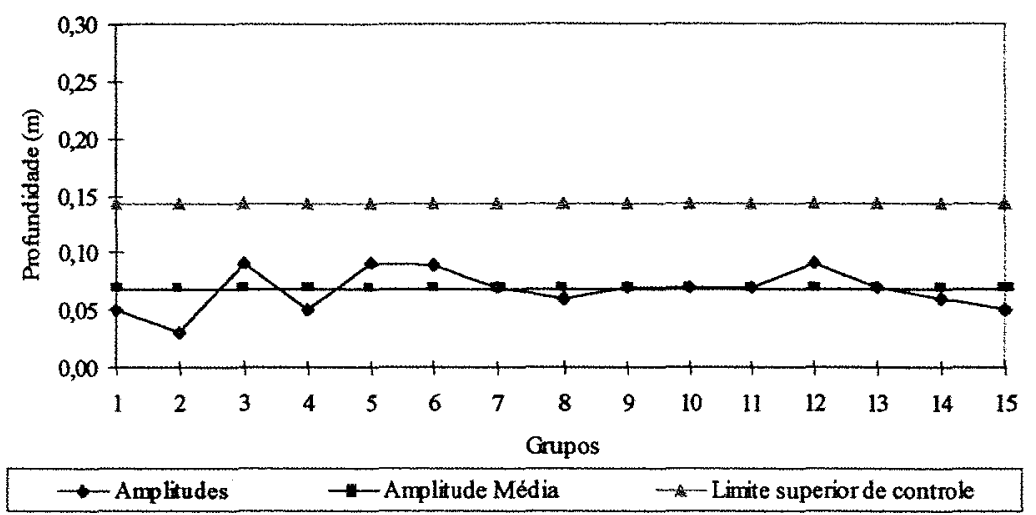

Figura 16 - Carta de controle com amplitudes, para a operação de escarificação na linha de preparo, na área A2.

São apresentados, na Figura 17, os resultados da avaliação na operação de escarificação, na linha de preparo, na área A1. A amplitude dos dados variou de 0,15 a $0,40 \mathrm{~m}$ e a maior ocorrência encontrada foi de $0,3 \mathrm{~m}$, enquanto que a recomendação da operação era que fosse realizada a $0,25 \mathrm{~m}$. Os dados aceitáveis dentro da área somaram $22,7 \%$ do total apresentado. Na área A2 (Figura 18), houve uma redução da amplitude, a qual variou de 0,2 a $0,325 \mathrm{~m}$, com $40,0 \%$ dentro do intervalo desejado. Ainda, a maior ocorrência anotada foi a profundidade de $0,25 \mathrm{~m}$, com $30,7 \%$ dos pontos amostrados.

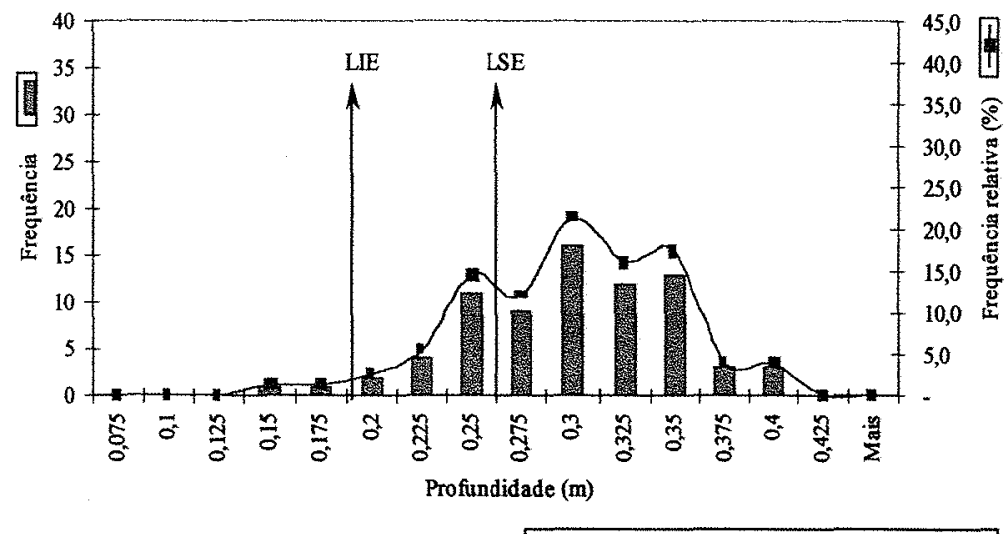

LIE LSE $\longrightarrow$ limites de especificacta

Figura 17 - Histograma de distribuição da profundidade de escarificação, na linha de preparo, na área A1. 


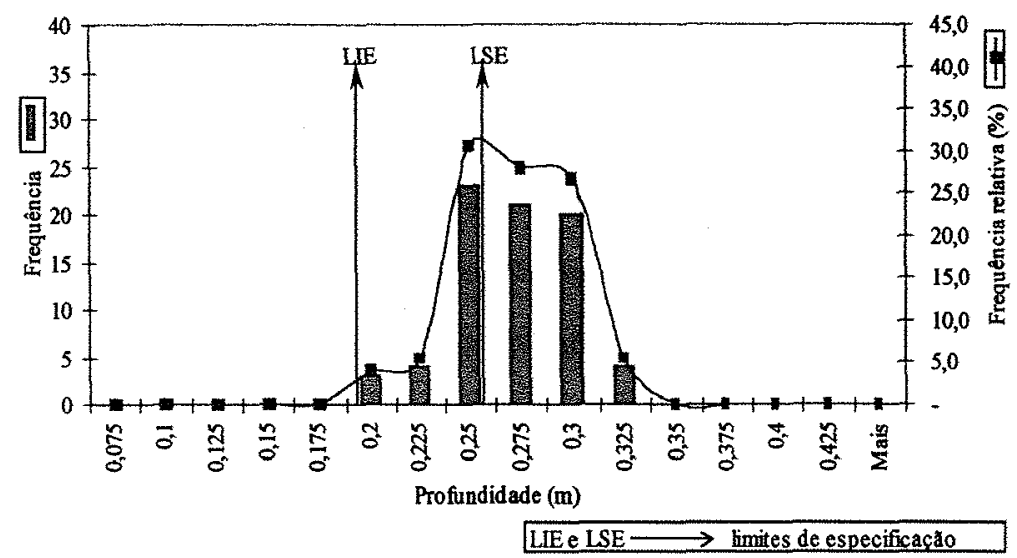

Figura 18 - Histograma de distribuição da profundidade de escarificação, na linha de preparo, na área A2.

A melhoria com a introdução das técnicas de CEP resultou em um aumento de $76,5 \%$ dos pontos da malha dentro do intervalo desejado pelo corpo técnico, sendo que somente para a profundidade $0,25 \mathrm{~m}$, o ganho com a aplicação das técnicas do CEP foi de 109,1\%. A Tabela 3 confirma as diferenças estatísticas mostradas nas cartas de controle.

Tabela 3. Análise estatística (teste $\mathrm{T}$ ) para os dados da operação de escarificação, na linha de preparo do solo.

\begin{tabular}{lcccc}
\hline Tratamento & Média $(\mathrm{m})$ & Desv. Padr. & Prob $>|\mathrm{T}|$ & \\
\hline Sem CEP & 0,288 & 0,0511 & 0,0001 & A \\
Com CEP & 0,261 & 0,0289 & 0,0001 & B
\end{tabular}

Tratamentos com letras distintas são diferentes estatisticamente, ao nível de significância de $5 \%$

\subsubsection{Entrelinha de preparo do solo}

Observando-se a carta de controle com médias na entrelinha de preparo do solo, para a área $\mathrm{A} 1$, verifica-se que a média encontrada foi de $0,17 \mathrm{~m}$ para os pontos amostrados, e do total de 15 grupos, os quais variaram de 0,13 a $0,22 \mathrm{~m}$, apenas 3 estão 
dentro dos padrões especificados para a operação. Apesar disso, o processo encontrou-se dentro de controle (Figura 19). Na área A2 (Figura 20), após as mudanças implementadas com as técnicas do CEP, observou-se que a variação dos dados foi menor, indo de 0,17 a $0,22 \mathrm{~m}$, com média de $0,20 \mathrm{~m}$. Apesar de 7 grupos de pontos se encontrarem fora dos limites especificados para a operação, de 0,20 a $0,25 \mathrm{~m}$, constatouse que os 15 grupos variaram menos em torno da média, ainda estando dentro do controle estatístico.

Desse modo, a implantação do CEP, apesar de não satisfazer os padrões desejados, trouxe a médias dos dados mais próxima ao limite inferior, aumentando-a em $15,3 \%$.

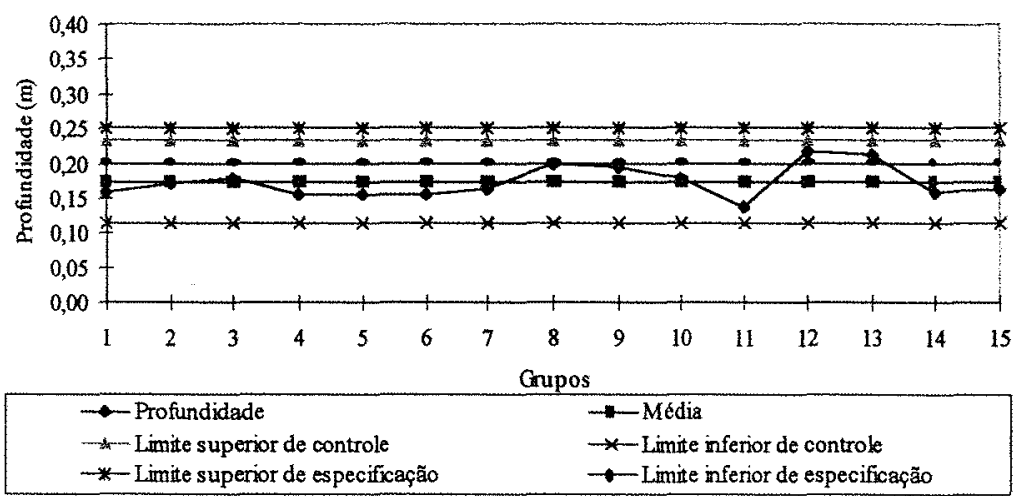

Figura 19 - Carta de controle com médias, para a operação de escarificação na entrelinha de preparo, na área $\mathrm{A} 1$.

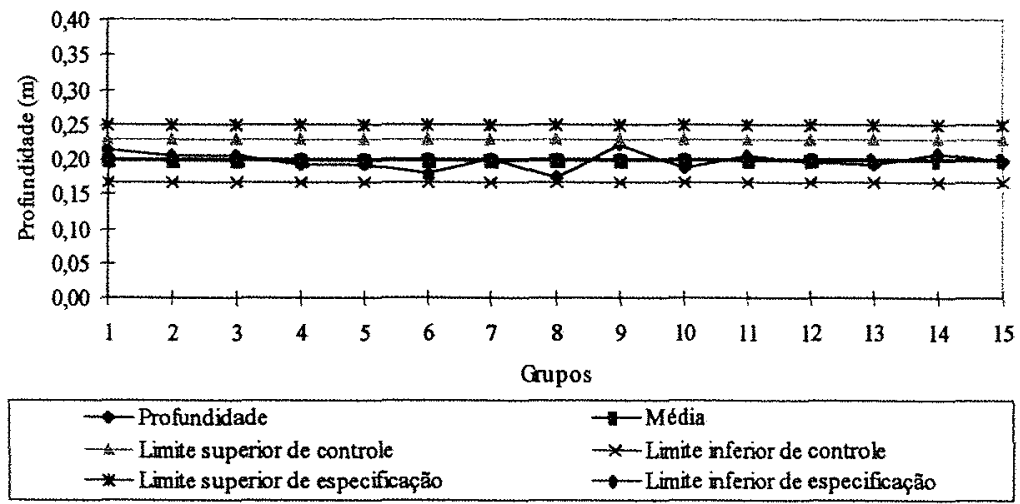

Figura 20 - Carta de controle com médias, para a operação de escarificação na entrelinha de preparo, na área $\mathrm{A} 2$. 
Constatou-se que na área Al, a média encontrada de amplitudes entre os grupos foi de $0,10 \mathrm{~m}$ (Figura 21). Já para a área A2 (Figura 22), visualizou-se uma menor variação de valores, com média atingida de $0,05 \mathrm{~m}$. Desse modo, a introdução do CEP resultou em uma redução média da amplitude dos dados dentre os grupos de $46,0 \%$.

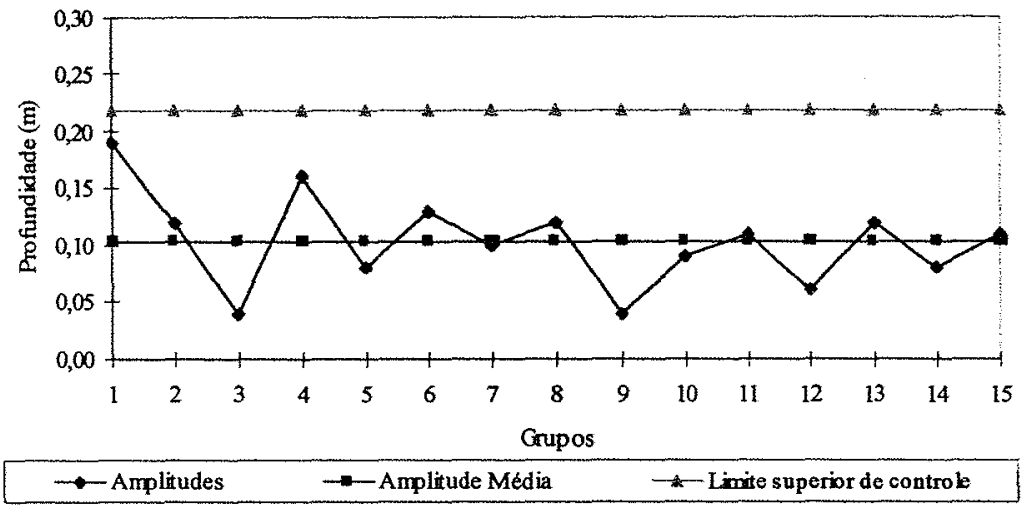

Figura 21 - Carta de controle com amplitudes, para a operação de escarificação na entrelinha de preparo, na área A1.

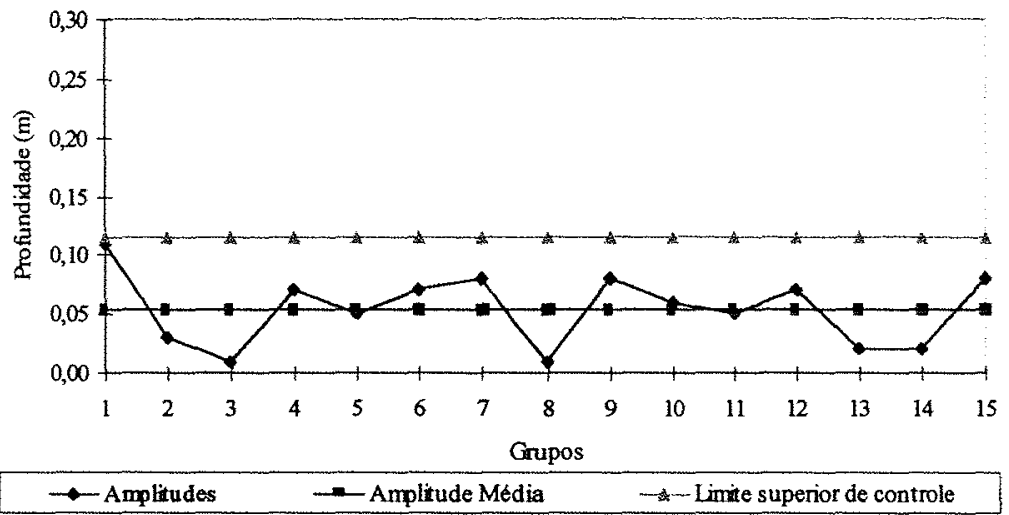

Figura 22 - Carta de controle com amplitudes, para a operação de escarificação na entrelinha de preparo, na área A2.

$\mathrm{Na}$ Figura 23, são apresentados os resultados referentes à operação de escarificação para a área A1. A amplitude da profundidade variou de 0,1 a $0,3 \mathrm{~m}$ e a maior ocorrência encontrada foi a profundidade de $0,20 \mathrm{~m}$, enquanto que a recomendação (padrão) da operação era que a mesma fosse efetuada entre 0,20 e 0,25 m. Os dados aceitáveis dentro da área obtiveram $45,3 \%$ do total apresentado. A área A2 (Figura 23) revela uma diminuição da amplitude, a qual variou de 0,15 a $0,30 \mathrm{~m}$, com 
concentração de pontos em $0,20 \mathrm{~m}$. Pela comparação dos histogramas, observou-se que as modificações efetuadas causaram uma concentração maior dos dados ao redor do valor desejado, com $72,0 \%$ da freqüência relativa.

A melhoria com a introdução das técnicas de CEP resultaram em um aumento de $58,9 \%$ dos pontos da malha dentro do intervalo desejado pelo corpo técnico. A Tabela 4 confirma as diferenças estatísticas mostradas nas cartas de controle e histogramas.

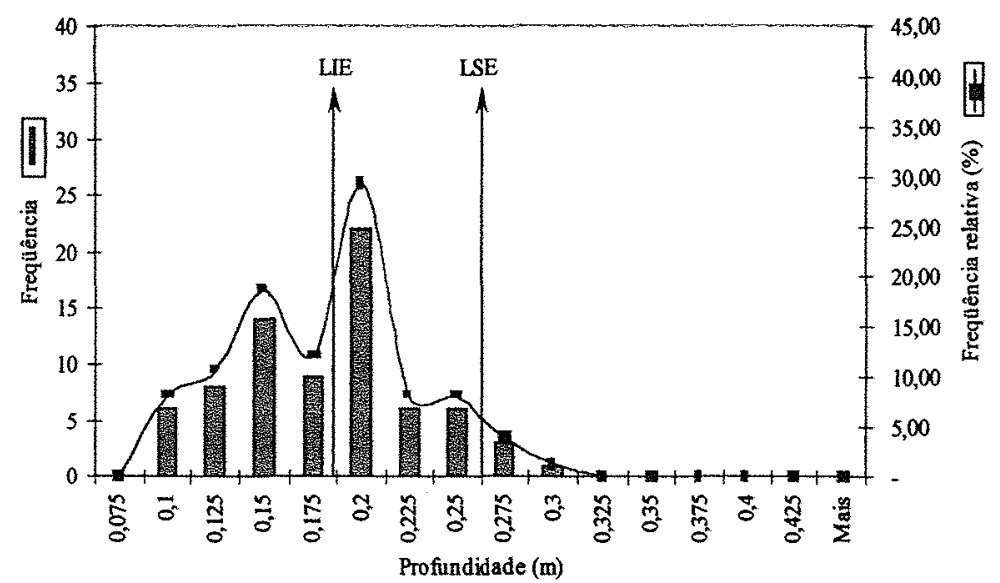

LIE L LSE $\longrightarrow$ Iimites de especificação

Figura 23 - Histograma de distribuição da profundidade de escarificação, na entrelinha de preparo, na área A1.

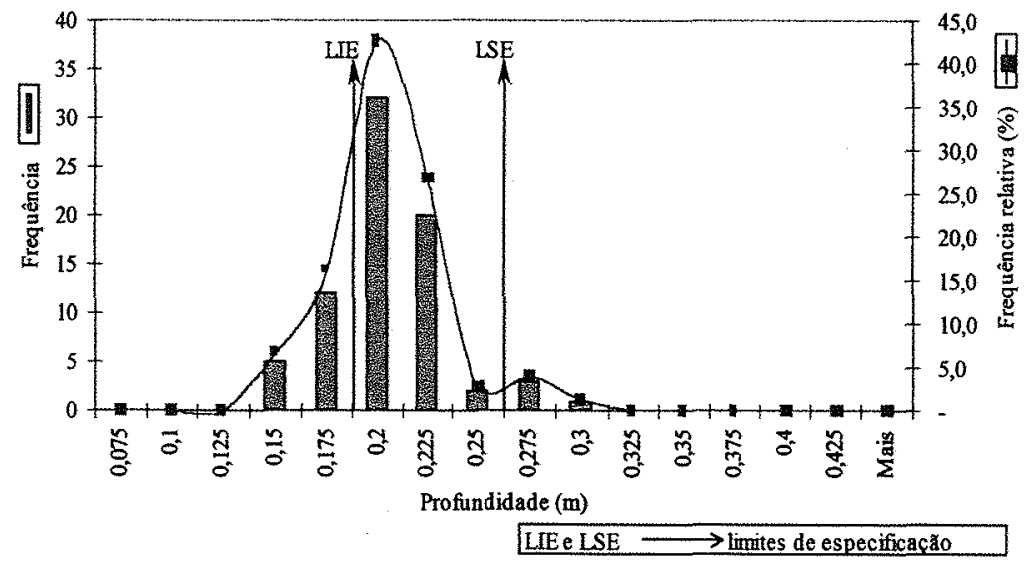

Figura 24 - Histograma de distribuição da profundidade de escarificação, na entrelinha de preparo, na área A2. 
Tabela 4. Análise estatística para os dados da operação de escarificação, na entrelinha de preparo do solo.

\begin{tabular}{lcccc}
\hline Tratamento & Média $(\mathrm{m})$ & Desv. Padr. & Prob $>|\mathrm{T}|$ & \\
\hline Sem CEP & 0,172 & 0,0289 & 0,0001 & $\mathbf{A}$ \\
Com CEP & 0,197 & 0,0511 & 0,0001 & $\mathbf{B}$ \\
\hline
\end{tabular}

Tratamentos com letras distintas são diferentes estatisticamente, ao nível de significância de $5 \%$

\subsection{OPERAÇÃo DE GRAdAGEM}

$\mathrm{Na}$ carta de controle com médias, na gradagem, para a área $\mathrm{A} 1$, verifica-se que a média encontrada foi de $0,07 \mathrm{~m}$ para os pontos amostrados, e do total de 15 grupos, os quais variaram de 0,06 a $0,08 \mathrm{~m}$, nenhum esteve dentro dos padrões especificados para a operação, que foi torrões com diâmetros menores que $0,04 \mathrm{~m}$. Apesar disso, o processo encontrou-se dentro de controle (Figura 25). Na área A2 (Figura 26), após a implementação das técnicas do CEP, observou-se que a variação dos dados foi menor, indo de 0,05 a $0,07 \mathrm{~m}$, com média de 0,06 m. Apesar de ainda não observar-se grupos dentro das especificações desejadas, a operação encontrou-se dentro de controle estatístico. A implantação do CEP, apesar de não satisfazer os padrões desejados, trouxe a médias dos dados mais próxima ao limite superior, reduzindo-a em 9,8\%.

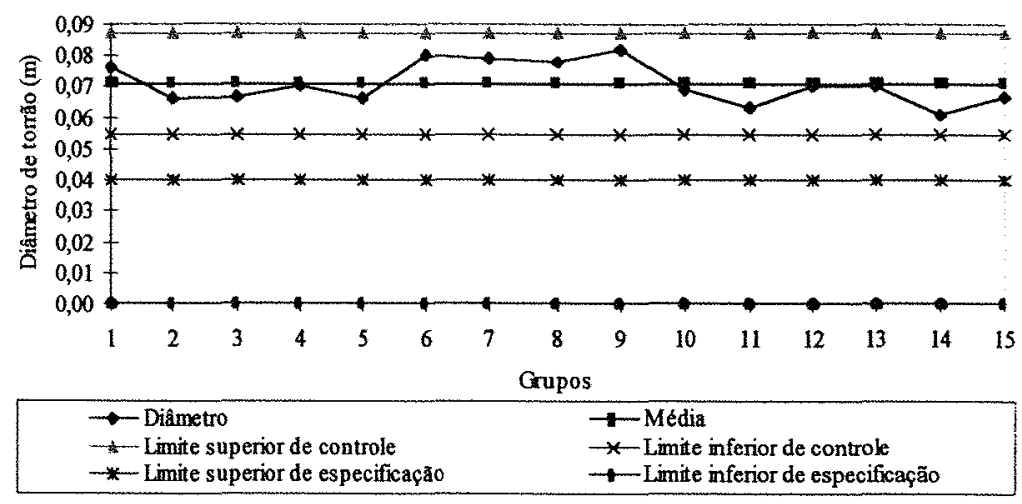

Figura 25 - Carta de controle com médias, para a operação de gradagem, na área A1. 

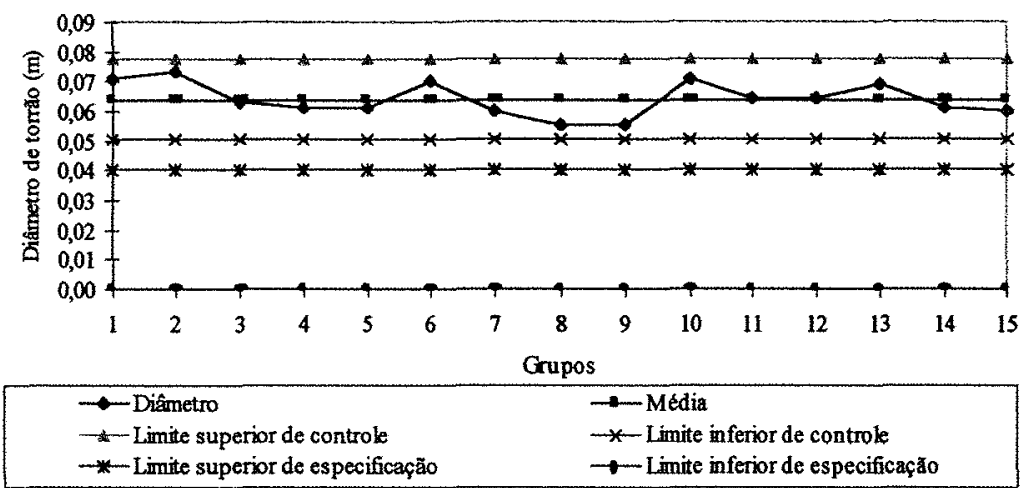

Figura 26 - Carta de controle com médias, para a operação de gradagem, na área A2.

Ainda, analisando a gradagem, constatou-se que na área A1, a média encontrada de amplitudes entre os grupos para o diâmetro de torrão foi de $0,028 \mathrm{~m}$ (Figura 27). Já para a área A2 (Figura 28), visualizou-se uma menor variação de valores, com média atingida de $0,023 \mathrm{~m}$. Desse modo, a introdução do $\mathrm{CEP}$ resultou em uma redução média da amplitude dos dados dentre os grupos de $17,8 \%$.

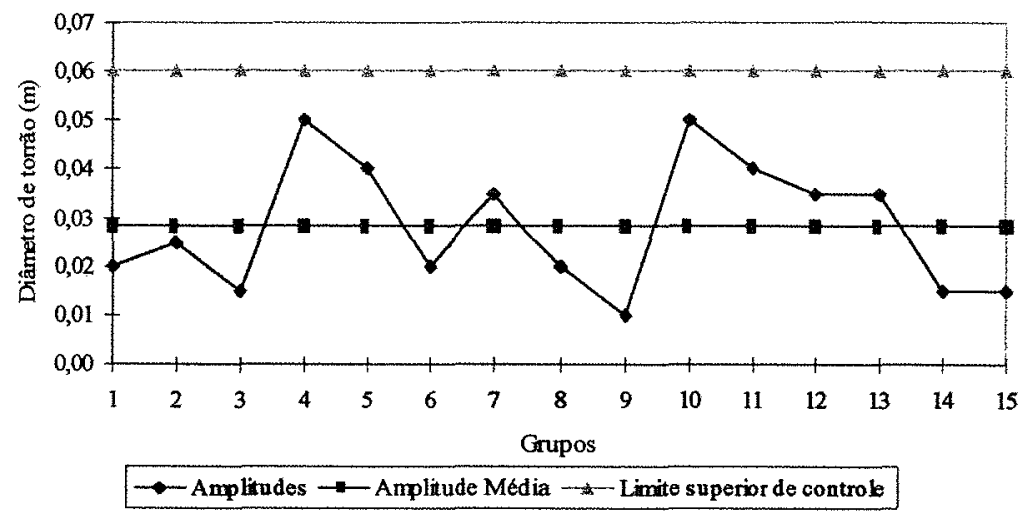

Figura 27 - Carta de controle com amplitudes, para a operação de gradagem, na área A1. 


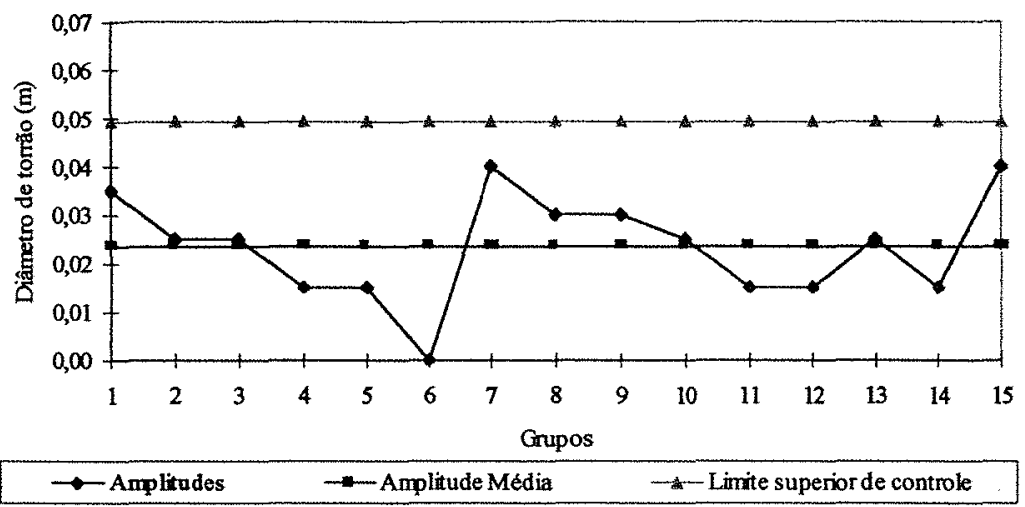

Figura 28 - Carta de controle com amplitudes, para a operação de gradagem, na área A2.

$\mathrm{Na}$ Figura 29, são apresentados os resultados referentes à operação de gradagem para a área A1. A amplitude da profundidade variou de 0,04 a $0,09 \mathrm{~m}$ e a maior ocorrência encontrada foi o diâmetro de $0,07 \mathrm{~m}$, enquanto que a recomendação (padrão) da operação era que o mesmo fosse menor que $0,04 \mathrm{~m}$. Os dados aceitáveis dentro da área obtiveram 5,3\% do total apresentado. A área A2 (Figura 30) revela um aumento dos valores desejados, com concentração de pontos em $0,07 \mathrm{~m}$. Pela comparação dos histogramas, observou-se que as modificações efetuadas causaram uma concentração maior dos dados ao redor do valor desejado, com $9,3 \%$ da freqüência relativa dentro do intervalo delimitado pelos limites de especificação.

A melhoria com a introdução das técnicas de CEP resultou em um aumento de $75,0 \%$ dos pontos da malha dentro do intervalo desejado pelo corpo técnico. Além disso, houve redução do número de torrões de diâmetro de $0,09 \mathrm{~m}$ em $91,7 \%$. A Tabela 5 confirma as diferenças estatísticas mostradas nas cartas de controle e histogramas.

Tabela 5. Análise estatística (teste T) para os dados da operação de gradagem.

\begin{tabular}{lcccc}
\hline Tratamento & Média $(\mathrm{m})$ & Desv. Padr. & Prob $>|\mathrm{T}|$ & \\
\hline Sem CEP & 0,071 & 0,0122 & 0,0008 & $\mathbf{A}$ \\
Com CEP & 0,065 & 0,0106 & 0,0009 & B
\end{tabular}

Tratamentos com letras distintas são diferentes estatisticamente, ao nivel de significância de $5 \%$ 


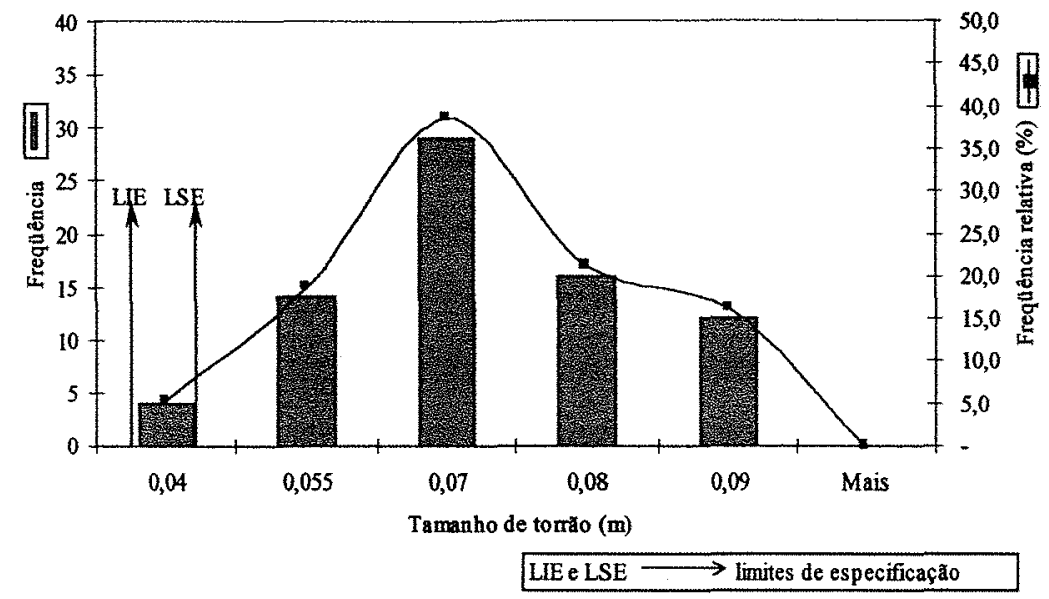

Figura 29 - Histograma de distribuição do tamanho de torrões, na gradagem, na área A1.

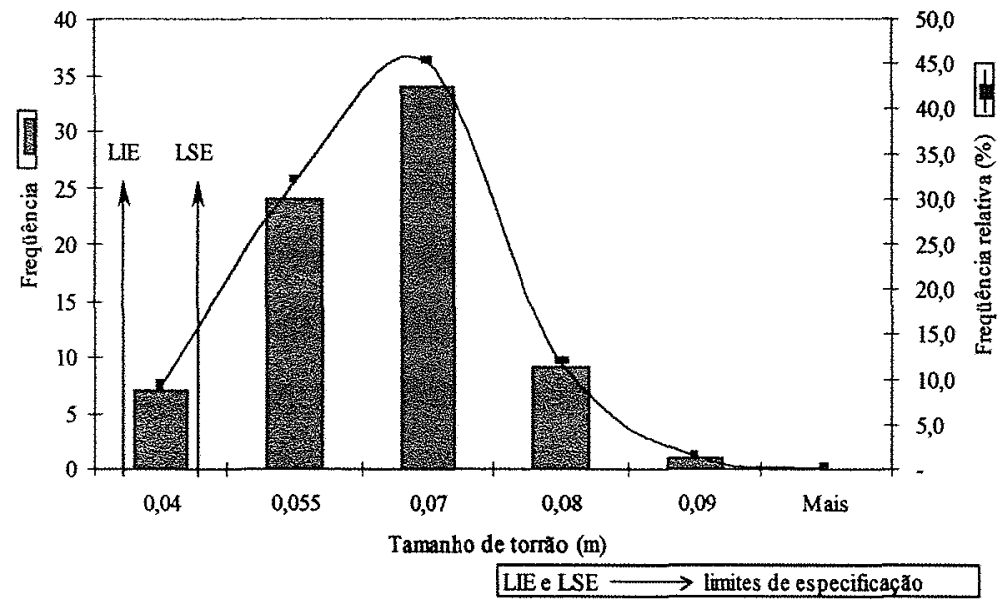

Figura 30 - Histograma de distribuição do tamanho de torrões, na gradagem, na área A2.

\subsection{OPERAÇÃo dE SEMEAdura}

\subsubsection{Geral}

Avaliando os dados médios da semeadora, notou-se que os espaçamentos duplos, na área A1 contabilizam $28,6 \%$ do total, os normais, $61,0 \%$ e os espaçamentos falhos, $10,4 \%$ (Figura 31). Entretanto, o espaçamento de plantas desejado, que se encontra entre 
0,20 e $0,25 \mathrm{~m}$, apenas foi alcançado em $20,8 \%$ do total amostrado. Já na área A2, os espaçamentos falhos caíram para $9,9 \%$, os duplos somaram $24,5 \%$, e os normais, $65,6 \%$, com os espaçamentos desejados somando $24,7 \%$ (Figura 32 ).

Pela comparação dos histogramas, foi verificado um aumento de espaçamentos normais, com a implantação das técnicas do CEP, em 7,4\%, no geral. A queda dos falhos foi de $4,8 \%$ e a dos espaçamentos duplos foi de $14,3 \%$, mas o mais importante é que os espaçamentos desejáveis cresceram em $8,2 \%$. Em ambas as áreas, a semeadora apresentou dados aceitáveis maiores que 60,0\% recomendados, segundo Coelho (1996).

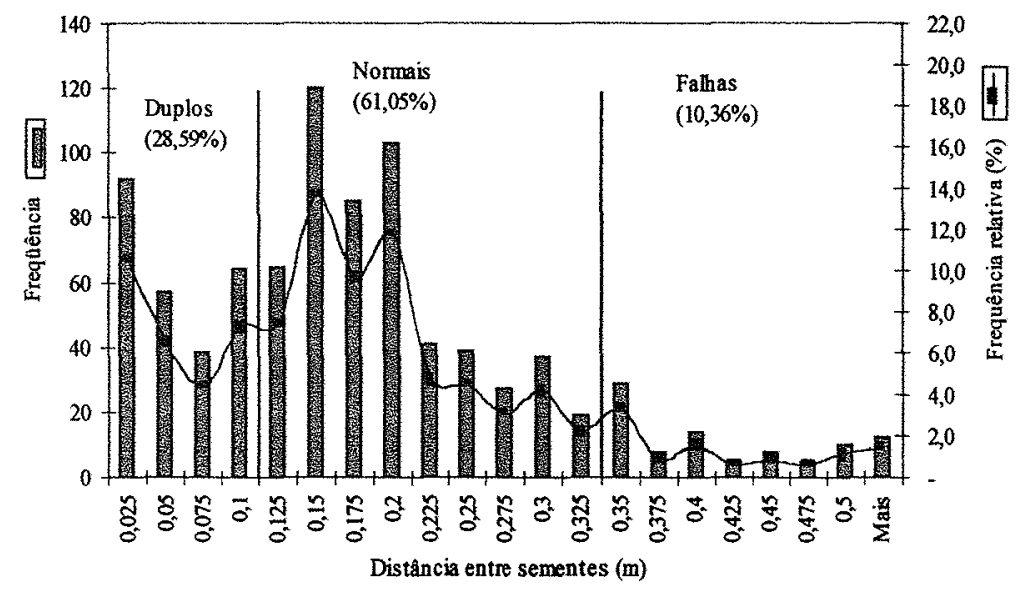

Figura 31 - Histograma dos espaçamentos medidos, para a área A1.

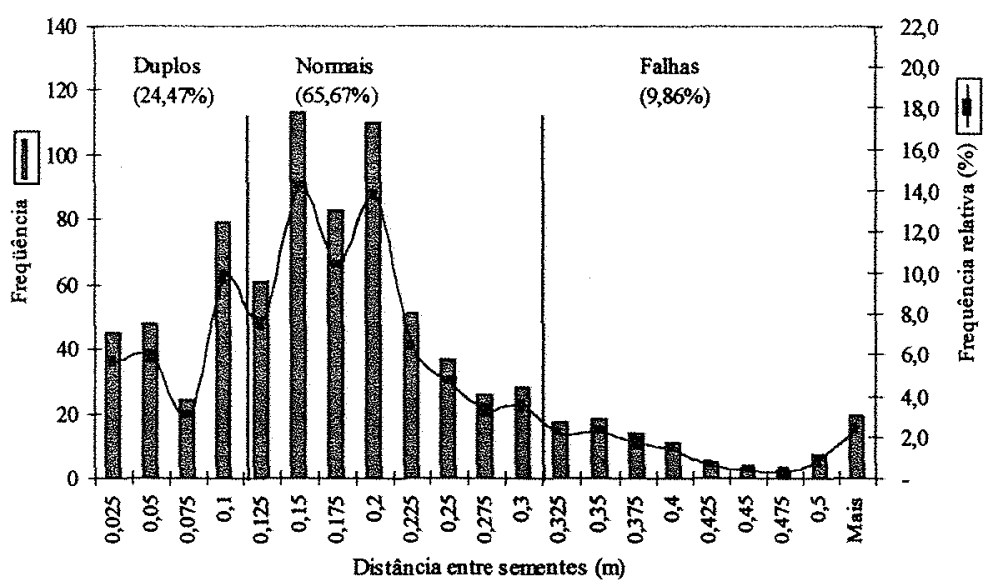

Figura 32 - Histograma dos espaçamentos medidos, para a área A2. 


\subsubsection{Avaliação das unidades}

Observando os dados obtidos na operação de semeadura da unidade 1 da semeadora, na área A1, notou-se que os espaçamentos normais somaram $63,7 \%$ do total, as falhas perfazem 7,9\% e os duplos, $28,4 \%$. Dentro dos normais, os espaçamentos desejados foram alcançados em 20,5\% (Figura 33). Para a área A2, verificou-se que os normais somaram $55,2 \%$, as falhas, $7,6 \%$ e os duplos, $37,1 \%$ dos espaçamentos medidos, com os desejados alcançando $22,9 \%$ (Figura 34).

Pela comparação dos histogramas, foi verificado um aumento de espaçamentos normais, com a implantação das técnicas do CEP, em 7,4\%, no geral. A queda dos falhos foi de $4,8 \%$ e a dos espaçamentos duplos foi de $14,3 \%$, mas o mais importante é que os espaçamentos desejáveis cresceram em 9,1\%.

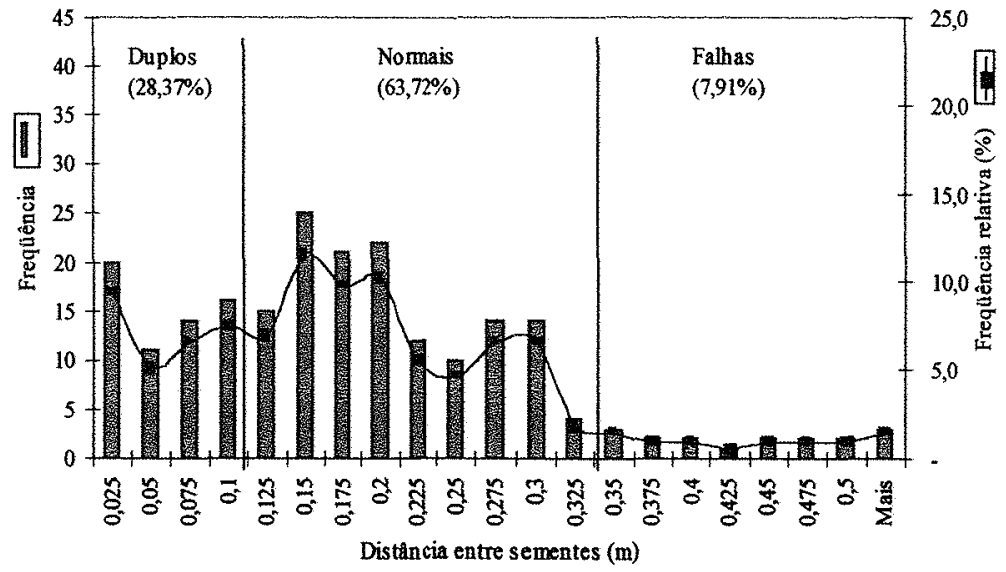

Figura 33 - Histograma dos espaçamentos medidos, para a área A1, para a unidade 1 da semeadora. 


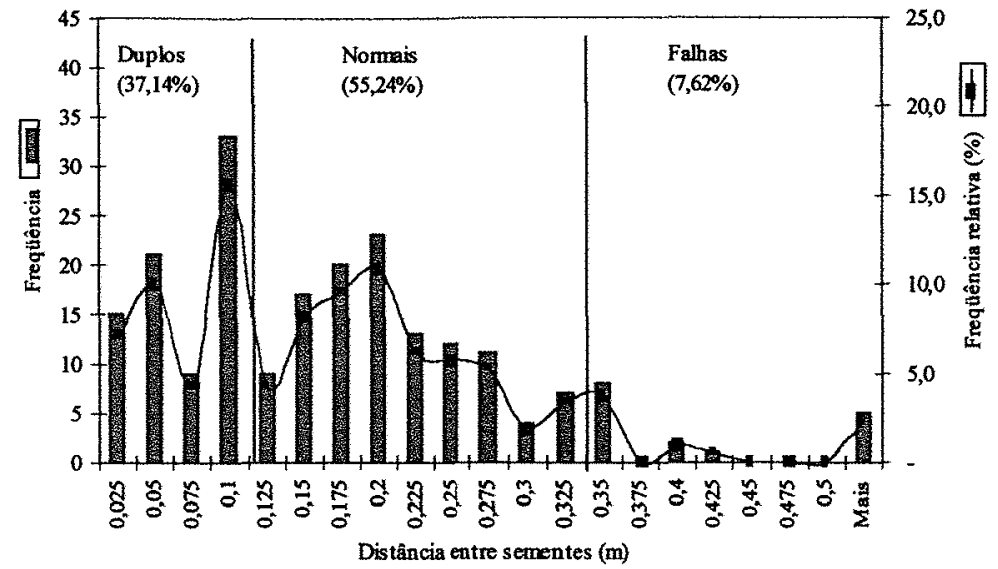

Figura 34 - Histograma dos espaçamentos medidos, para a área A2, para a unidade 1 da semeadora.

Avaliando os dados da operação de semeadura da unidade 2 da semeadora, para a área $\mathrm{A} 1$, notou-se que os espaçamentos normais somaram $64,8 \%$ do total, com as falhas perfazendo $10,0 \%$ e os duplos, $25,2 \%$. Os espaçamentos desejados, situados entre 0,2 e $0,25 \mathrm{~m}$, totalizou $20,9 \%$ do total amostrado (Figura 35). Já na área A2, os normais somaram $62,6 \%$, as falhas, $9,8 \%$ e os duplos, $27,6 \%$ dos espaçamentos medidos, com os desejados apresentando 25,6\% (Figura 36). Pela comparação dos histogramas, houve uma redução de 3,4\% nos espaçamentos normais, aumento de $9,4 \%$ dos duplos, as falhas decresceram $1,5 \%$, porém houve crescimento de espaçamentos desejados em $8,3 \%$ para a unidade 2 da semeadora.

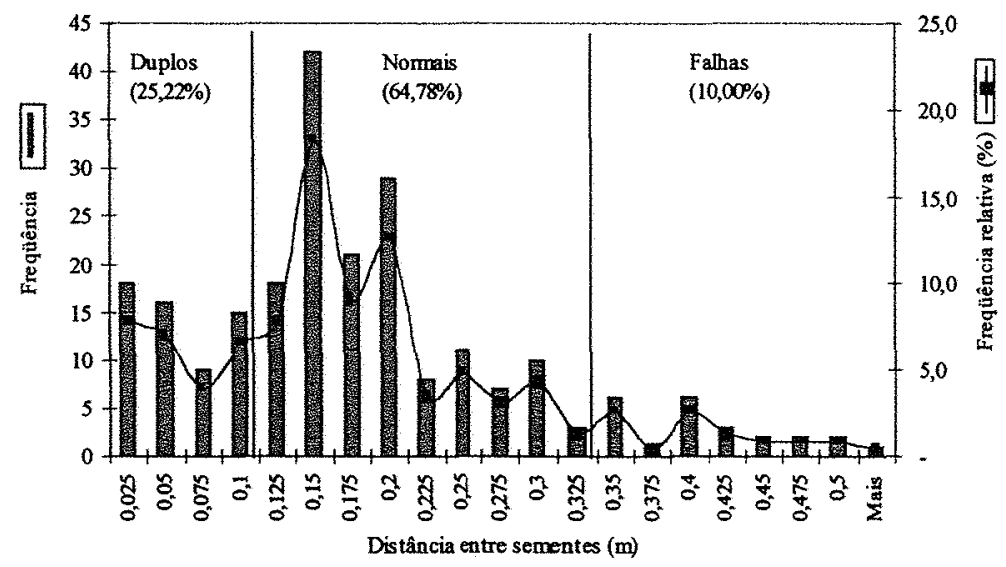

Figura 35 - Hıstograma dos espaçamentos medidos, para a área Al, para a unidade 2 da semeadora. 


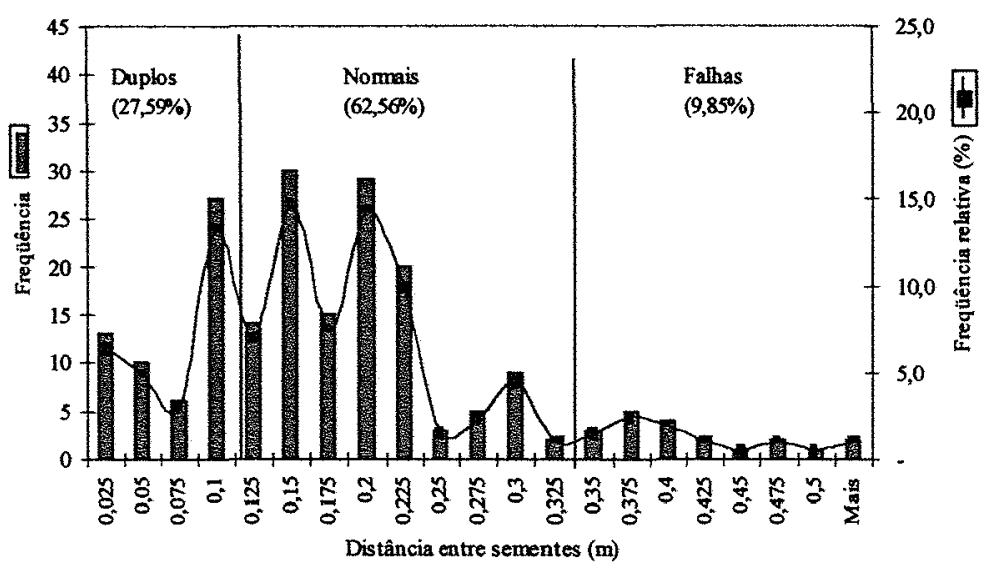

Figura 36 - Histograma dos espaçamentos medidos, para a área A2, para a unidade 2 da semeadora.

Medindo-se os espaçamentos da unidade 3, na área $\mathrm{Al}$, notou-se que os normais somaram $68,5 \%$ do total, as falhas perfizeram $11,6 \%$ e os duplos, $19,9 \%$, os espaçamentos desejados ficaram com 23,1\% (Figura 37). Comparando-os com a área A2, os normais somaram $77,9 \%$, as falhas, $9,6 \%$ e os duplos, $15,5 \%$ dos espaçamentos medidos; os espaçamentos desejados atingiram 25,6\% do total amostrado (Figura 38).

Comparando-se os dados pelos histogramas, observa-se que houve um aumento de $9,3 \%$ nos espaçamentos normais, redução de $22,3 \%$ dos duplos, as falhas decresceram $16,5 \%$, com um crescimento de espaçamentos desejados em 10,8\% para a unidade 3 da semeadora.

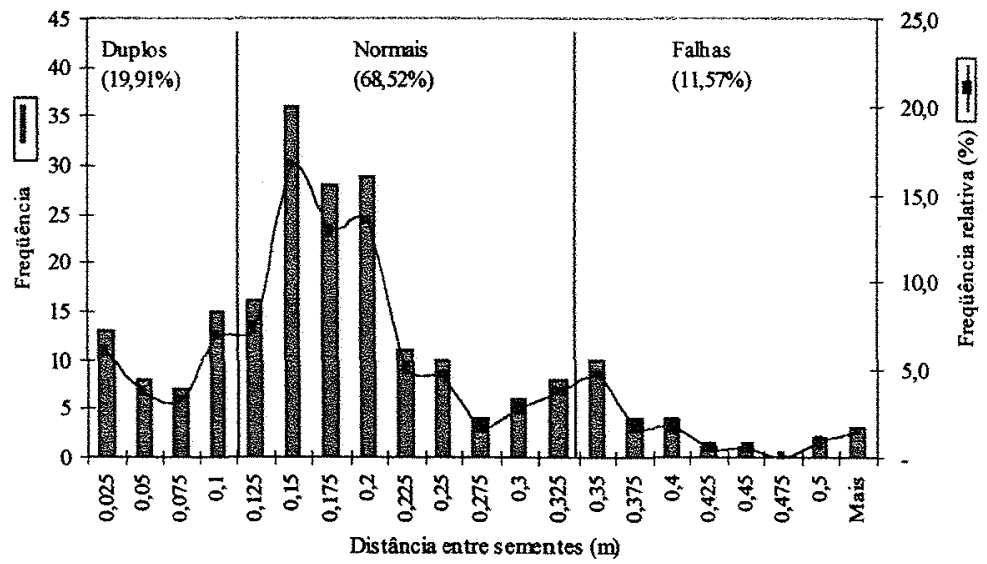

Figura 37 - Histograma dos espaçamentos medidos, para a área A1, para a unidade 3 da semeadora. 


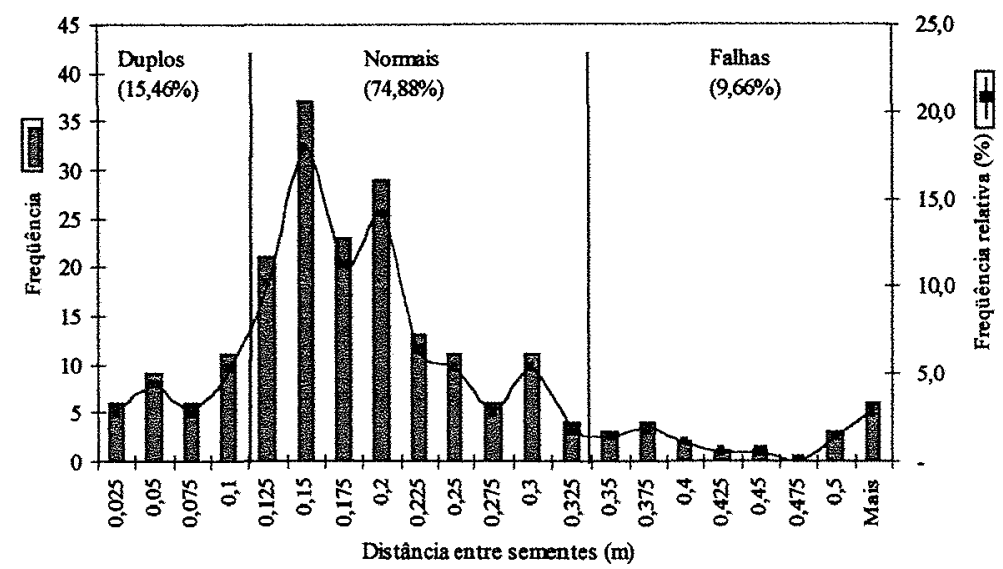

Figura 38 - Histograma dos espaçamentos medidos, para a área A2, para a unidade $3 \mathrm{da}$ semeadora.

Para a unidade 4 da semeadora, na área $\mathrm{A} 1$, notou-se que os espaçamentos normais somaram $47,0 \%$ do total, as falhas perfizeram $12,0 \%$ e os duplos, $41,0 \%$. Nos espaçamentos normais, os desejados foram alcançados em 18,9\% (Figura 39). Já para a área $\mathrm{A} 2$, verificou-se que os normais somaram $70,7 \%$, as falhas, $12,7 \%$ e os duplos, 16,6\% dos espaçamentos medidos, com os desejados alcançando 24,9\% (Figura 40).

Comparando-se os histogramas, verificou-se um aumento de espaçamentos normais, com a implantação do controle, em 25,5\%. A queda dos duplos foi de $63,3 \% \mathrm{e}$ os falhos aumentaram 11,5\%, entretanto o importante foi que os espaçamentos desejáveis cresceram em $9,7 \%$.

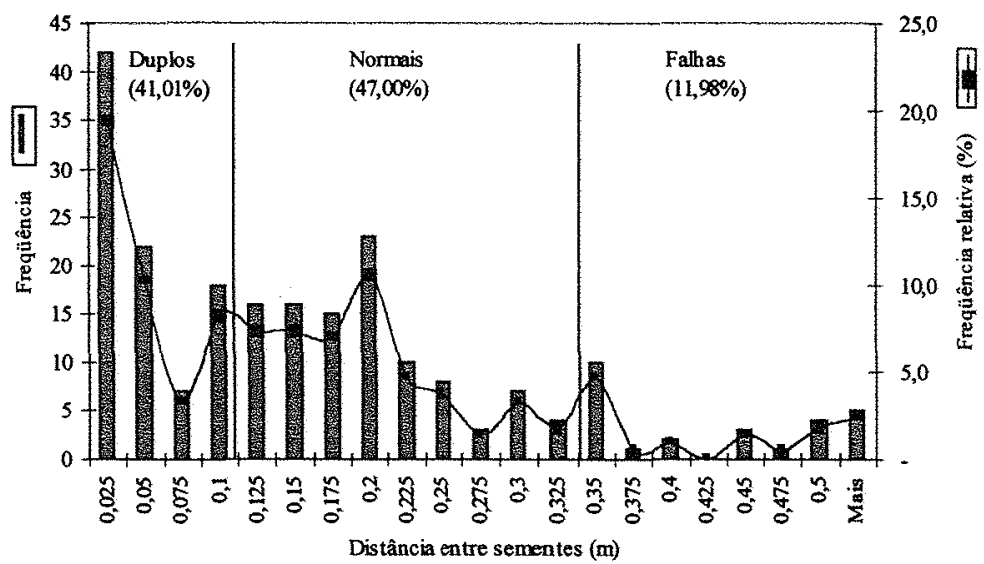

Figura 39 - Histograma dos espaçamentos medidos, para a área Al, para a unidade $4 \mathrm{da}$ semeadora. 


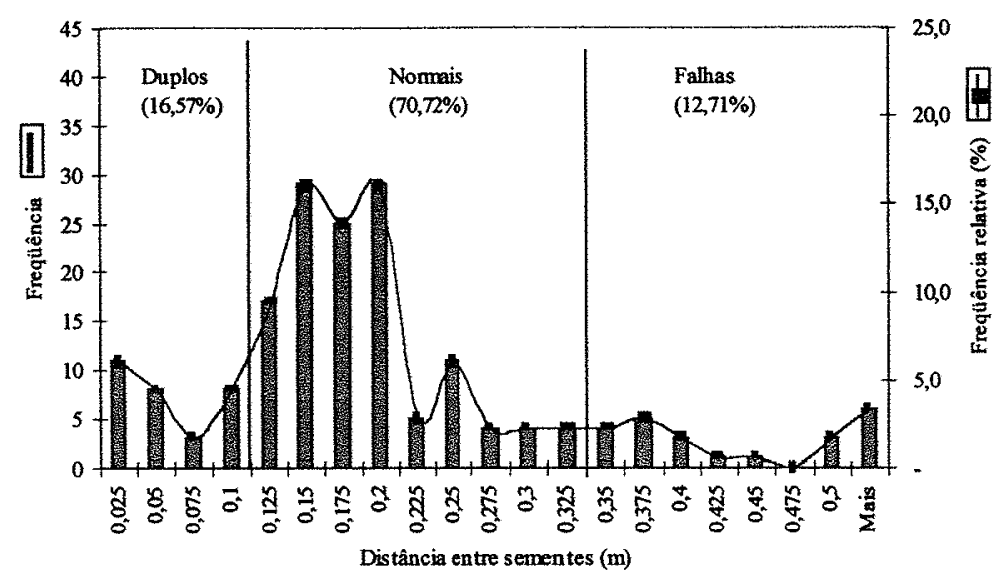

Figura 40 - Histograma dos espaçamentos medidos, para a área A2, para a unidade 4 da semeadora.

Segundo as normas da ABNT (1995) e o apresentado por Coelho (1996), nenhuma unidade da semeadora em questão apresentou o padrão máximo de coeficiente de variação de espaçamentos entre plantas de $50 \%$, sendo que houve valores de $58,5 \%$ a $95,4 \%$ registrados em ambas as áreas. Os valores mínimos para espaçamentos normais variaram de $47,0 \%$ a $77,9 \%$, próximos ao mínimo exigido para o tipo de semeadora, que é $60,0 \%$. A unidade 4 foi a que apresentou maior variação de comportamento dentro desse quesito (Tabela 6).

Tabela 6. Dados estatísticos das unidades semeadoras, coletados a campo.

\begin{tabular}{|c|c|c|c|c|c|}
\hline & & Duplos (\%) & Normais (\%) & Falhas (\%) & Desvio padrăo \\
\hline \multirow{4}{*}{ Sem CEP } & Unidade 1 & 28,37 & 63,72 & 7,91 & 0,1124 \\
\hline & Unidade 2 & 25,22 & 64,78 & 10,00 & 0,1103 \\
\hline & Unidade 3 & 19,91 & 68,52 & 11,57 & 0,1059 \\
\hline & Unidade 4 & 41,01 & 47,00 & 11,98 & 0,1527 \\
\hline \multirow{4}{*}{ Com CEP } & Unidade 1 & 37,14 & 55,24 & 7,62 & 0,1224 \\
\hline & Unidade 2 & 27,59 & 62,56 & 9,85 & 0,1070 \\
\hline & Unidade 3 & 15,46 & 77,88 & 9,66 & 0,1162 \\
\hline & Unidade 4 & 16,57 & 70,72 & 12,71 & 0,1221 \\
\hline & & $\mathrm{CV}(\%)$ & Média $(m)$ & Precisão (\%) & Desvio da média (\%) \\
\hline \multirow{4}{*}{ Sem CEP } & Unidade 1 & 64,95 & 0,173 & 44,94 & $-1,17$ \\
\hline & Unidade 2 & 64,88 & 0,170 & 44,12 & 0,58 \\
\hline & Unidade 3 & 58,49 & 0,181 & 42,35 & $-5,85$ \\
\hline & Unidade 4 & 95,46 & 0,160 & 61,09 & 6,43 \\
\hline \multirow{4}{*}{ COM CEP } & Unidade 1 & 74,16 & 0,165 & 48,94 & 7,43 \\
\hline & Unidade 2 & 62,91 & 0,170 & 42,78 & 4,63 \\
\hline & Unidade 3 & 61,47 & 0,189 & 46,47 & $-6,03$ \\
\hline & Unidade 4 & 64,58 & 0,189 & 48,82 & $-6,03$ \\
\hline
\end{tabular}


Apesar das diferenças numéricas, sob uma análise estatística mais clássica, os dados coletados na operação de semeadura não apresentaram diferenças significativas entre as áreas A1 e A2, quando analisados sob o teste T. Os espaçamentos duplos, as falhas e os normais não são diferentes entre si (Tabela 7).

Tabela 7. Análise estatística (teste T) para os dados da operação de semeadura, a campo.

\begin{tabular}{llrrrl}
\hline & Tratamento & Espaçamento (m) & Desv. Padr. & Prob $>|\mathrm{T}|$ & \\
\hline \multirow{2}{*}{ Falhas } & Sem CEP & 9,960 & 2,092 & 0,4185 & A \\
& Com CEP & 7,865 & 4,200 & 0,4063 & A \\
& Normais & 66,600 & 9,824 & 0,4456 & A \\
& Sem CEP & 61,005 & 9,560 & 0,4455 & A \\
& Com CEP & 24,190 & 10,223 & 0,5386 & A \\
& Sem CEP & 28,627 & 8,962 & 0,5381 & A \\
& Com CEP & $2,0,8$ &
\end{tabular}

Tratamentos com letras distintas são diferentes estatisticamente, ao nível de significância de $5 \%$

\subsection{Altura de planta}

A altura das plantas foi mensurada para ambos os tratamentos. Os valores apresentados são valores médios para cada semana de medição. Verificou-se que a maior amplitude entre as área A1 e A2 ocorreu na primeira semana de fevereiro, com 13,0 cm de diferença média entre as plantas, e a menor foi notada na primeira semana de março, com $3 \mathrm{~cm}$ de diferença média. A partir da quarta semana de fevereiro, a taxa de crescimento diminuiu, já que chegava o início da floração das plantas de milho. Os valores variavam de $0,63 \mathrm{~m}$ a $1,85 \mathrm{~m}$ para a área $\mathrm{A} 1$; e de $0,74 \mathrm{~m}$ a $1,88 \mathrm{~m}$ para a área A2 (Figura 41). 


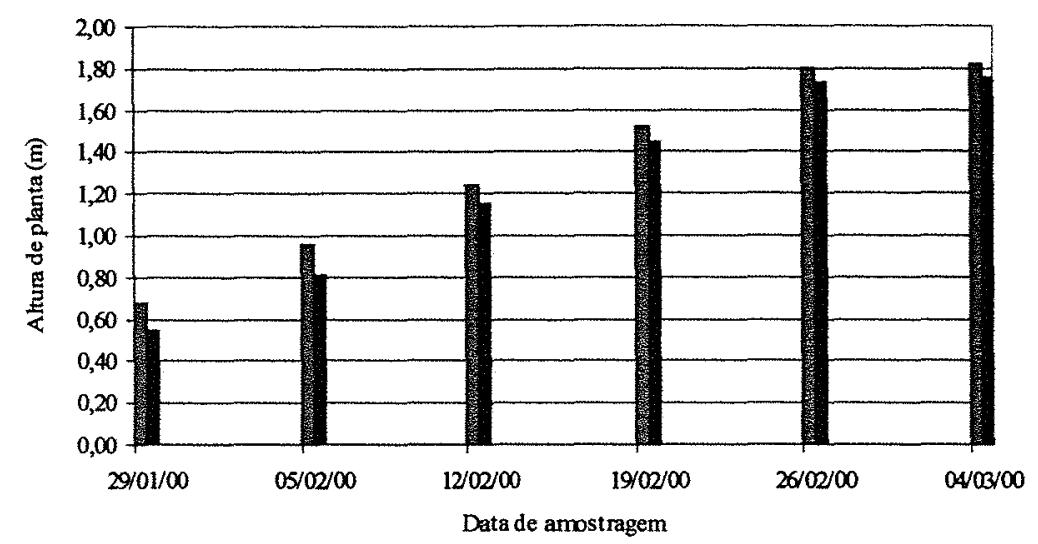

Com CEP Sem CEP

Figura 41 - Evolução das alturas médias das plantas de milho, em função dos tratamentos.

Correlacionando todas as alturas, sob os dois tratamentos, para todas as épocas de amostragem, verificou-se um coeficiente de correlação de $83,3 \%$ entre as alturas de plantas da área A1 e da área A2. Desse modo, foi possível predizer o ganho de altura das plantas na área $\mathrm{A} 2$ comparativamente com as plantas da área $\mathrm{A} 1$, com $83,3 \%$ de certeza (Figura 42).

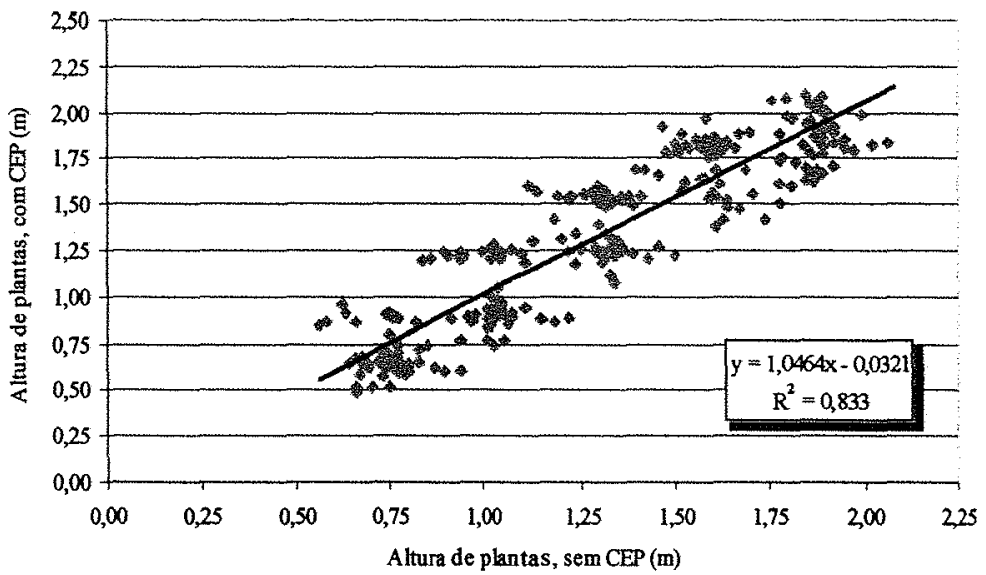

Figura 42 - Correlação entre as alturas das plantas de milho, sob os dois tratamentos.

Estatisticamente, todas as médias de alturas de plantas diferem entre si, quando comparados os tratamentos (Tabela 8). 
Tabela 8. Análise estatística (teste T) para os dados de altura de planta.

\begin{tabular}{|c|c|c|c|c|c|}
\hline & Tratamento & Média (m) & Desv. Padr. & Prob $>|\mathrm{T}|$ & \\
\hline \multirow{2}{*}{$29 / 01 / 00$} & Com CEP & 0,677 & 0,0044 & 0,0001 & $\mathbf{A}$ \\
\hline & Sem CEP & 0,546 & 0,0124 & 0,0000 & B \\
\hline \multirow{2}{*}{$05 / 02 / 00$} & Com CEP & 0,957 & 0,0273 & 0,0003 & $\mathbf{A}$ \\
\hline & Sem CEP & 0,806 & 0,0178 & 0,0004 & B \\
\hline \multirow{2}{*}{$12 / 05 / 00$} & Com CEP & 1,237 & 0,0349 & 0,0808 & $\mathbf{A}$ \\
\hline & Sem CEP & 1,146 & 0,0157 & 0,0003 & B \\
\hline \multirow{2}{*}{$19 / 02 / 00$} & Com CEP & 1,517 & 0,0026 & 0,0230 & $\mathbf{A}$ \\
\hline & Sem CEP & 1,446 & 0,0302 & 0,0001 & B \\
\hline \multirow{2}{*}{$26 / 02 / 00$} & Com CEP & 1,797 & 0,0061 & 0,0001 & $\mathbf{A}$ \\
\hline & Sem CEP & 1,726 & 0,0023 & 0,0007 & B \\
\hline \multirow{2}{*}{$04 / 03 / 00$} & Com CEP & 1,817 & 0,0042 & 0,0248 & $\mathbf{A}$ \\
\hline & Sem CEP & 1,758 & 0,0146 & 0,0111 & B \\
\hline
\end{tabular}

Tratamentos com letras distintas são diferentes estatisticamente, ao nível de significância de $5 \%$

\subsection{OPERAÇÃo dE COLHEITA}

\subsubsection{Produção de massa}

Analisando as seis repetições das 4 unidades da semeadora, notou-se uma variabilidade alta nos dados, indo de 1,06 a $1,45 \mathrm{~kg} \mathrm{MS} / \mathrm{m}$, para a área $\mathrm{A} 1$, com média de $1,12 \mathrm{~kg} \mathrm{MS} / \mathrm{m}$. Para a área $\mathrm{A} 2$, a variabilidade dos dados também foi um fato marcante, indo de 0,97 a $1,30 \mathrm{~kg} \mathrm{MS} / \mathrm{m}$. A unidade que apresentou uma maior diferença no stand de plantas foi a 1 , que apresentou médias de $1,12 \mathrm{~kg} \mathrm{MS} / \mathrm{m}$ (A1) e 1,61 kg $\mathrm{MS} / \mathrm{m}$ (A2), um ganho de 43,7\%, com a implantação das técnicas do CEP nas operações de preparo de solo. As unidades 2, 3 e 4, apresentaram decréscimo no peso médio de colmos de 7,1\%, 10,2\% e 8,4\%, respectivamente (Figura 43).

Ao serem analisados estatisticamente sob o teste Tukey e ANOVA, os dados das áreas A1 e A2 mostraram-se ser iguais, sob nível de significância de 5\%. Entretanto, 
quando os dados das unidades são confrontados, concluiu-se com os dados provenientes que a unidade 4 é diferente estatisticamente às unidades 1 e 3 . Ainda, pôde-se afirmar que existe uma interação entre os tratamentos e as unidades da semeadora (Tabelas 9 e 10).

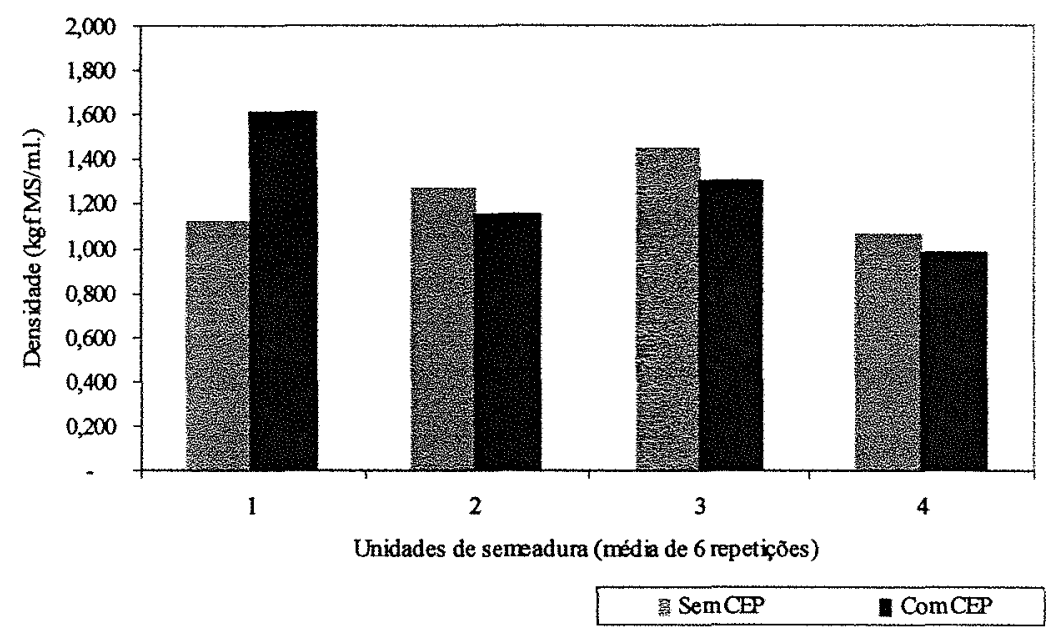

Figura 43 - Produção de massa medida, em função das unidades da semeadora e dos tratamentos.

Tabela 9. Análise estatística (teste Tukey) para os dados da operação de colheita, em análise da produção de massa.

\begin{tabular}{lccccc}
\hline & $\begin{array}{c}\text { Produção de massa } \\
(\mathrm{kg} \mathrm{MS} / \mathrm{m})\end{array}$ & $\mathrm{N}$ & & \\
& 1,229 & 24 & $\mathbf{A}$ & \\
\hline Sem CEP & 1,260 & 24 & $\mathbf{A}$ & \\
Com CEP & & & & & \\
& 1,376 & 12 & B & \\
Unidade 3 & 1,364 & 12 & B & \\
Unidade 1 & 1,214 & 12 & B & C \\
Unidade 2 & 1,020 & 12 & & C \\
Unidade 4 & & & & & \\
\hline
\end{tabular}

$\overline{\text { Tratamentos com letras distintas são diferentes estatisticamente, ao nivel }}$ de significância de $5 \%$ 
Tabela 10. Análise estatística (ANOVA) para os dados da operação de colheita, em análise da produção de massa.

\begin{tabular}{lrrlr}
\hline & Soma Quad. & Méd. Quad. & F & Prob > F \\
\hline Tratamento & 0,012 & 0,0126 & 0,23 & 0,5725 \\
Unidade & 0,990 & 0,3301 & 8,48 & $0,0002^{*}$ \\
Trat. x Unid. & 0,827 & 0,2756 & 7,08 & $0,0006^{*}$ \\
\hline
\end{tabular}

* Dados com diferenças estatisticas, ao nivel de significância de $5 \%$

\subsubsection{Relação espiga/planta e folha/planta}

Ao se analisar as seis repetições das 4 unidades da semeadora, notou-se um comportamento distinto entre os dois parâmetros estudados, a média das 6 repetições da relação espiga/planta decresceu da área A1 para a da A2 (com exceção da unidade 3), e o inverso ocorreu quando se estudou a relação folha/espiga. Os valores observados para ambas as áreas foram da ordem de $40 \%$ e $20 \%$ para a relação espiga/planta e folha/planta, respectivamente (Figura 44).

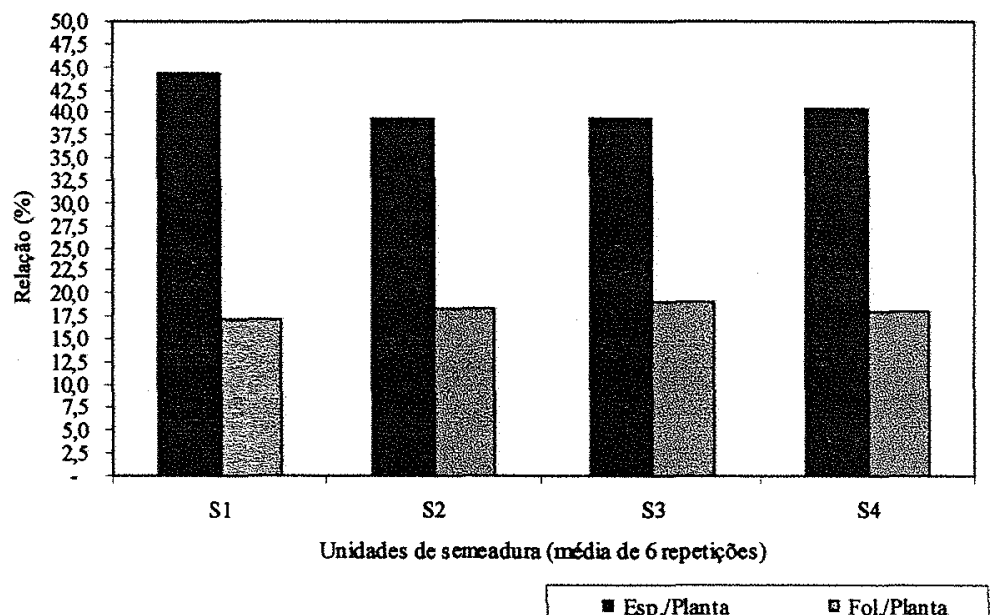

Figura 44 - Dados das relações espiga/planta e folha/planta, em função das repetições, para a área A1. 
Já para a área A2, verificou-se que existe um tendência de crescimento da relação espiga/planta no sentido da unidade 1 para a unidade 4. Observando os dados da relação folha/planta para o mesmo tratamento, notou-se uma situação inversa, ou seja, um decréscimo de valores no sentido da unidade 1 para a 4, também (Figura 45).

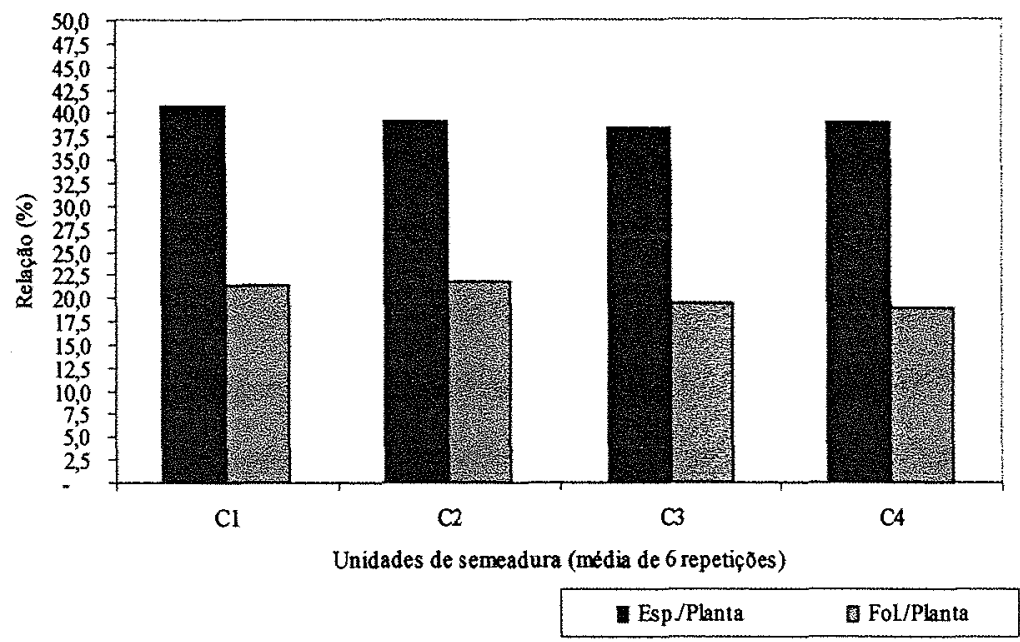

Figura 45 - Dados das relações espiga/planta e folha/planta, em função das repetições, para a área A2.

A amplitude de dados encontrada para a relação espiga/planta foi de 5,0\% e 4,5\%, para as áreas $\mathrm{A} 1$ e A2, respectivamente. Já para a relação folha/planta, a amplitude foi de 2,0\% e 3,1\%, para dados das áreas A1 e A2, respectivamente (Tabela 11).

Tabela 11. Dados médios das relações espiga/planta e folha/planta, para a operação de colheita.

\begin{tabular}{llrrrr}
\hline & & \multicolumn{4}{c}{ Dados médios (\%) } \\
\cline { 3 - 6 } & & Unidade 1 & Unidade 2 & Unidade 3 & Unidade 4 \\
\hline \multirow{2}{*}{ Espiga } & Sem CEP & 44,38 & 39,36 & 39,36 & 40,54 \\
& Com CEP & 40,63 & 36,16 & 38,33 & 38,86 \\
\multirow{2}{*}{ Folha } & Sem CEP & 17,05 & 18,16 & 19,06 & 18,05 \\
& Com CEP & 21,27 & 21,67 & 19,67 & 18,60 \\
\hline
\end{tabular}


Analisando estatisticamente, sob os testes Tukey e ANOVA, os dados das áreas A1 e A2 da relação espiga/planta mostraram-se ser iguais, sob o nível de significância de $5 \%$. O mesmo aconteceu quando os dados das unidades foram confrontados, concluiu-se que os dados provenientes das 4 unidades não diferem estatisticamente entre si (Tabelas 12 e 13).

Tabela 12. Análise estatística (teste Tukey) para os dados da operação de colheita, em análise da relação espiga/planta.

\begin{tabular}{lrlll}
\hline & Relação (\%) & $\mathrm{N}$ & \\
\hline Sem CEP & 29,814 & 24 & $\mathbf{A}$ \\
Com CEP & 29,578 & 24 & $\mathbf{A}$ \\
& & & \\
Unidade 1 & 30,571 & 12 & $\mathbf{B}$ \\
Unidade 2 & 29,314 & 12 & $\mathbf{B}$ \\
Unidade 3 & 29,284 & 12 & $\mathbf{B}$ \\
Unidade 4 & 29,612 & 12 & $\mathbf{B}$
\end{tabular}

Tratamentos com letras distintas são diferentes estatisticamente, ao nível de significância de 5\%

Tabela 13. Análise estatística (ANOVA) para os dados da operação de colheita, em análise da relação espiga/planta.

\begin{tabular}{lrrrr}
\hline & Soma Quad. & Méd. Quad. & F & Prob > F \\
\hline Tratamento & 0,671 & 0,6711 & 0,30 & 0,5888 \\
Unidade & 13,043 & 4,3477 & 1,92 & 0,1412 \\
\hline
\end{tabular}

Estatisticamente, sob o teste Tukey e ANOVA, os dados das áreas A1 e A2 da relação folha/planta mostraram-se ser diferentes, o mesmo aconteceu quando os dados das unidades foram confrontados. Concluiu-se que os dados provenientes das unidades 2 e 4 diferem estatisticamente entre si. $E$ ainda, pôde-se afirmar que existe uma interação entre os tratamentos e as unidades da semeadora (Tabelas 14 e 15). 
Tabela 14. Análise estatística (ANOVA) para os dados da operação de colheita, em análise da relação folha/planta.

\begin{tabular}{lrrrc}
\hline & Soma Quad. & Méd. Quad. & \multicolumn{1}{c}{ F } & Prob $>$ F \\
\hline Tratamento & 55,013 & 55,0129 & 45,49 & $0,0001^{*}$ \\
Unidade & 15,284 & 5,0948 & 4,21 & 0,0111 \\
Trat. $x$ Unid. & 36,635 & 12,2116 & 10,10 & $0,0001^{*}$ \\
\hline
\end{tabular}

*Dados com diferenças estatísticas, ao nível de signifícância de 5\%

Tabela 15. Análise estatística (teste Tukey) para os dados da operação de colheita, em análise da relação folha/planta.

\begin{tabular}{lrllll}
\hline & Relação (\%) & N & & \\
\hline Sem CEP & 20,221 & 24 & A & & \\
Com CEP & 18,080 & 24 & A & & \\
& & & & & \\
Unidade 2 & 19,919 & 12 & B & \\
Unidade 3 & 19,200 & 12 & B & C \\
Unidade 1 & 19,582 & 12 & B & C \\
Unidade 4 & 18,326 & 12 & & C \\
\hline
\end{tabular}

Tratamentos com letras distintas são diferentes estatisticamente, ao nivel de significância de 5\%

\subsubsection{Tamanho de partícula}

As amostras colhidas a campo e suas frações peneiradas foram estudadas a fim de se verificar a existência de uma correlação entre o peso medido em cada peneira e a umidade das amostras. Caso houvesse, haveriam dados para a criação de dispositivos práticos a campo como uma alternativa às peneiras de laboratório.

Os pesos das frações encontradas na peneira superior variaram de $1,7 \%$ a $8,3 \%$, com média de $3,3 \%$. Os valores na peneira intermediária foram de $52,6 \%$ a $66,8 \%$, com média de $60,3 \%$; e os valores da peneira inferior foram de $30,3 \%$ a $44,4 \%$, com média de $36,3 \%$. O valor médio da umidade encontrada nas 21 amostras foi $67,4 \%$, com extremos em $63,5 \%$ e $73,3 \%$ (Figura 46 ). 


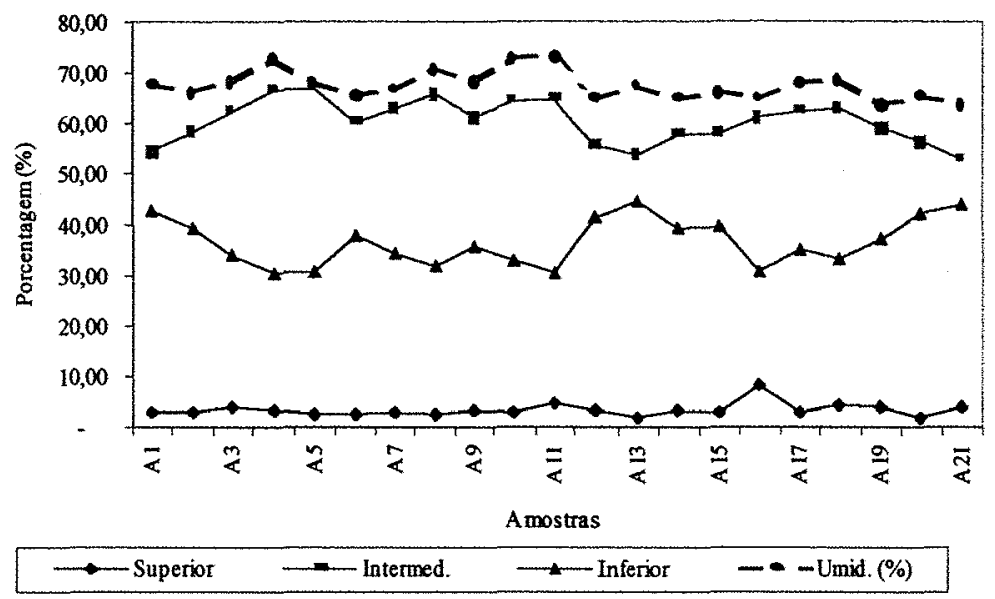

Figura 46 - Porcentagem do peso retido nas peneiras, e a umidade das amostras colhidas.

Quanto à correlação entre as porcentagens retidas nas peneiras e a umidade das amostras, não houve uma interação entre estes dois fatores, para nenhuma das peneiras, pois não foi possível estabelecer uma relação entre os fatores já que os coeficientes encontrados foram $0,7 \%, 49,7 \%$ e $38,3 \%$ para as peneiras superior, intermediária e inferior, respectivamente. Dessa forma, descartou-se a hipótese de haver alguma relação de interação entre os fatores (Figuras 47 a 49), visto que o coeficiente mínimo aceitável para uma correlação seria 80,0\%, segundo Vieira (1999).

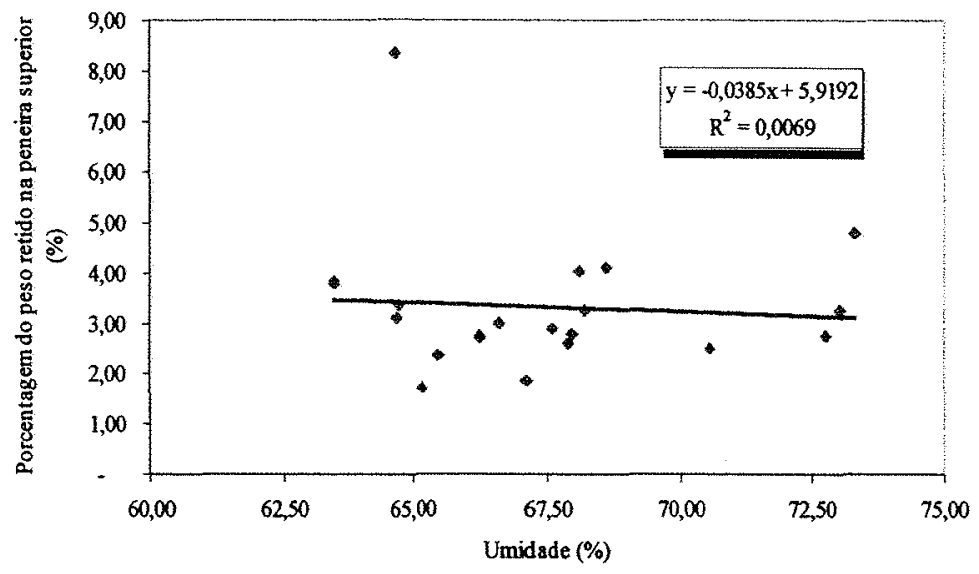

Figura 47 - Correlação entre a porcentagem do peso retido na peneira superior e a umidades das amostras. 


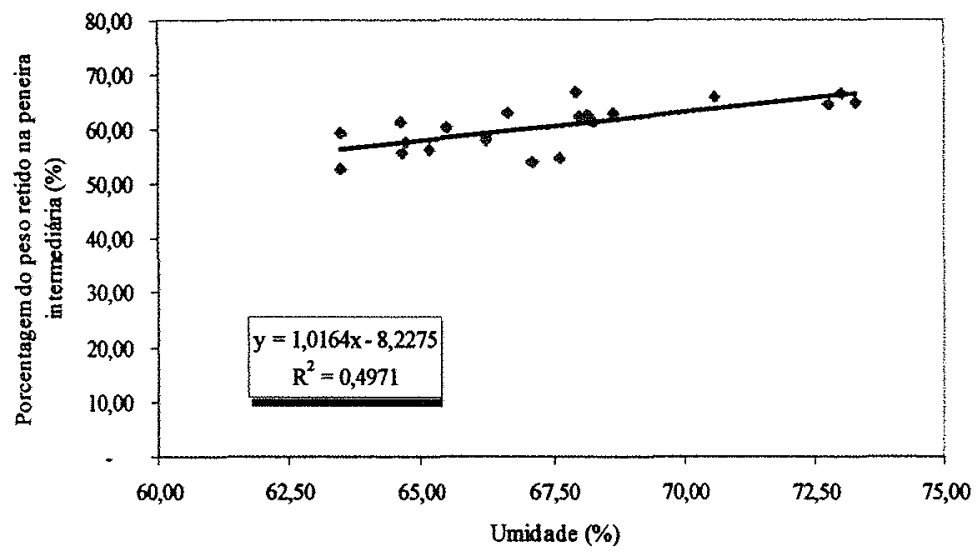

Figura 48 - Correlação entre a porcentagem do peso retido na peneira intermediária e a umidades das amostras.

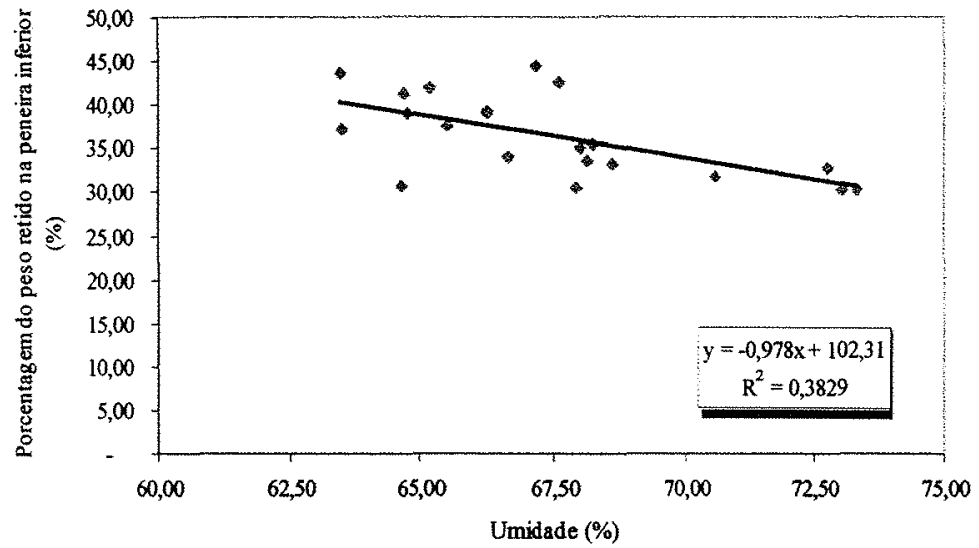

Figura 49 - Correlação entre a porcentagem do peso retido na peneira inferior e a umidades das amostras.

Foi feita a correlação entre o peso das frações retidas nas peneiras e os volumes que as mesmas ocupam. Novamente, não existiu a possibilidade de se criar ou desenvolver um mecanismo ou equação para determinação prática a campo, como uma alternativa às peneiras de laboratório, desenvolvidas nos EUA, pois encontrou-se os valores $12,7 \%, 22,8 \%$ e $69,9 \%$ (muito baixos) como coeficientes de correlação entre 
estes dois fatores para as peneiras superior, intermediária e inferior, respectivamente (Figuras 50 a 52 ).

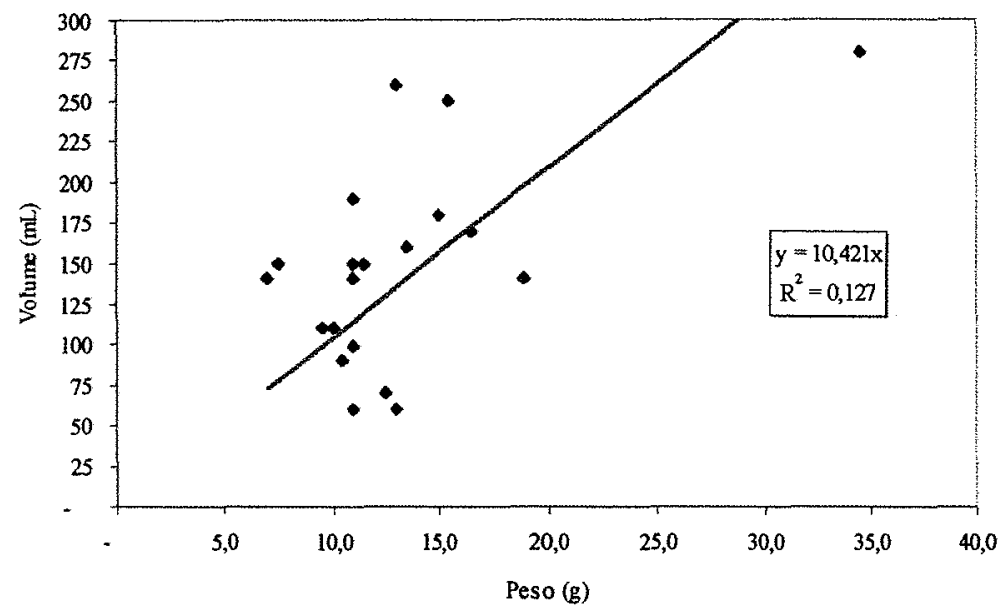

Figura 50 - Correlação entre a porcentagem do peso retido na peneira superior e o volume da fração.

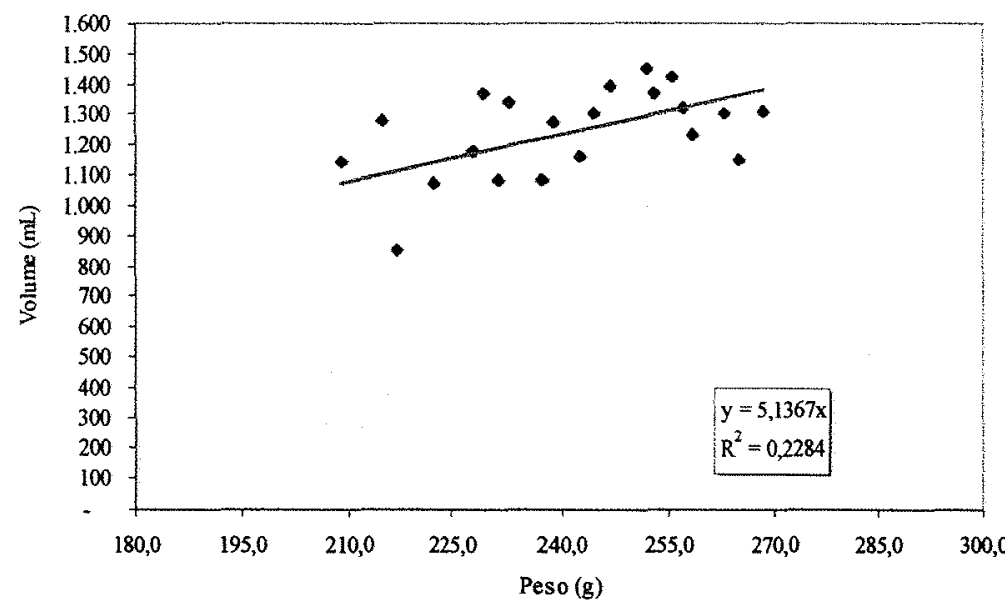

Figura 51 - Correlação entre a porcentagem do peso retido na peneira intermediária e o volume da fração. 


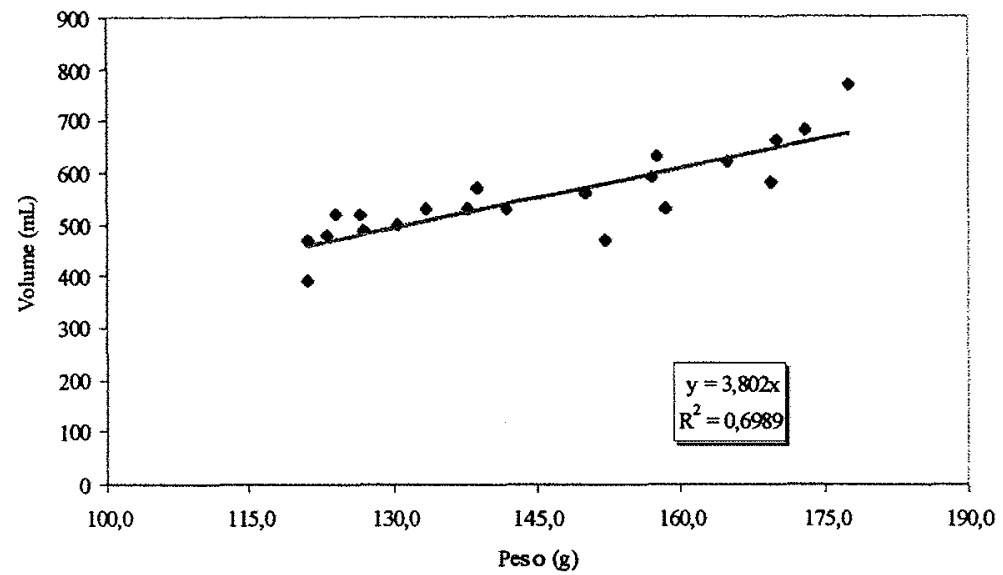

Figura 52 - Correlação entre a porcentagem do peso retido na peneira inferior e o volume da fração.

A correlação entre a densidade original da amostra e a densidade das frações retidas nas 3 peneiras foi estudada na tentativa de se verificar a existência de alguma relação entre esses fatores. O coeficiente de correlação entre a amostra original e as 3 peneiras foi de $0,96 \%, 1,24 \%$ e $4,78 \%$, para as peneiras superior, intermediária e inferior, respectivamente (Figuras 53 a 55).

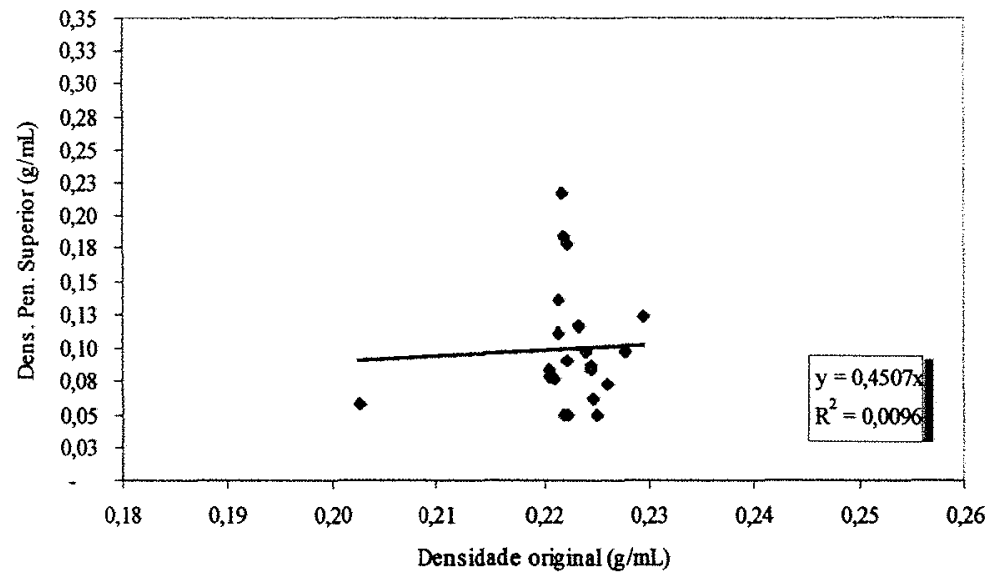

Figura 53 - Correlação entre a densidade do peso retido na peneira superior e a densidade original das amostras. 


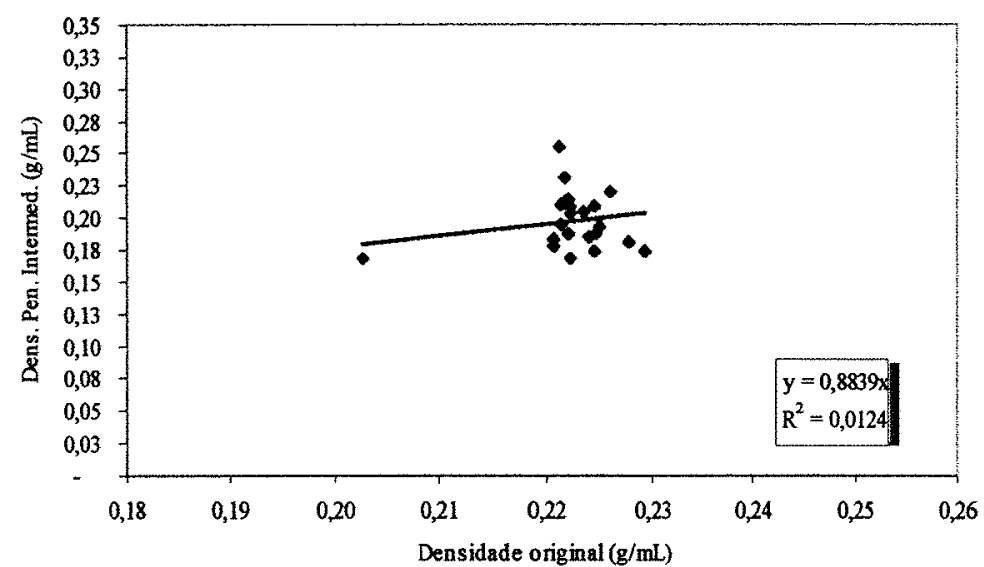

Figura 54 - Correlação entre a densidade do peso retido na peneira intermediária e a densidade original das amostras.

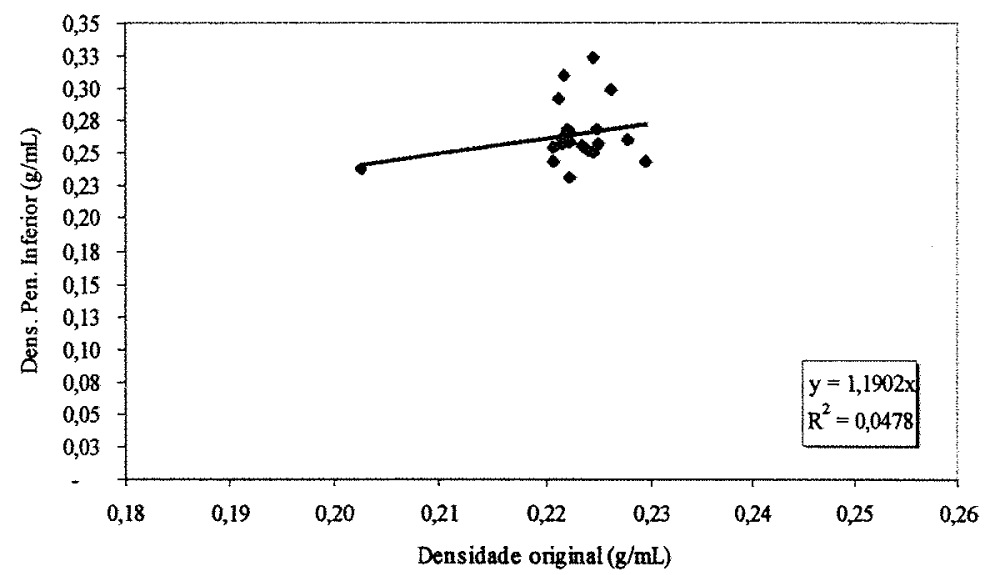

Figura 55 - Correlação entre a densidade do peso retido na peneira inferior e a densidade original das amostras.

Com base nos dados colhidos em laboratório, com a pesagem e medição das 21 amostras colhidas a campo, plotou-se os dados das peneiras no Gráfico de Weibull, para a determinação do tamanho e proporção das partículas da planta de milho na massa picada pela colhedora. Uma reta foi traçada no gráfico com base nos pontos das amostras, a qual permite que se faça um extrapolação do tamanho das partículas e suas respectivas proporções, dentro dos limites de $0,78 \mathrm{~cm}$ e $1,90 \mathrm{~cm}$. Assim, verificou-se que aproximadamente $52 \%$ do total das partículas picadas na massa possuíam tamanho até $1,0 \mathrm{~cm}$ (Figura 56). 


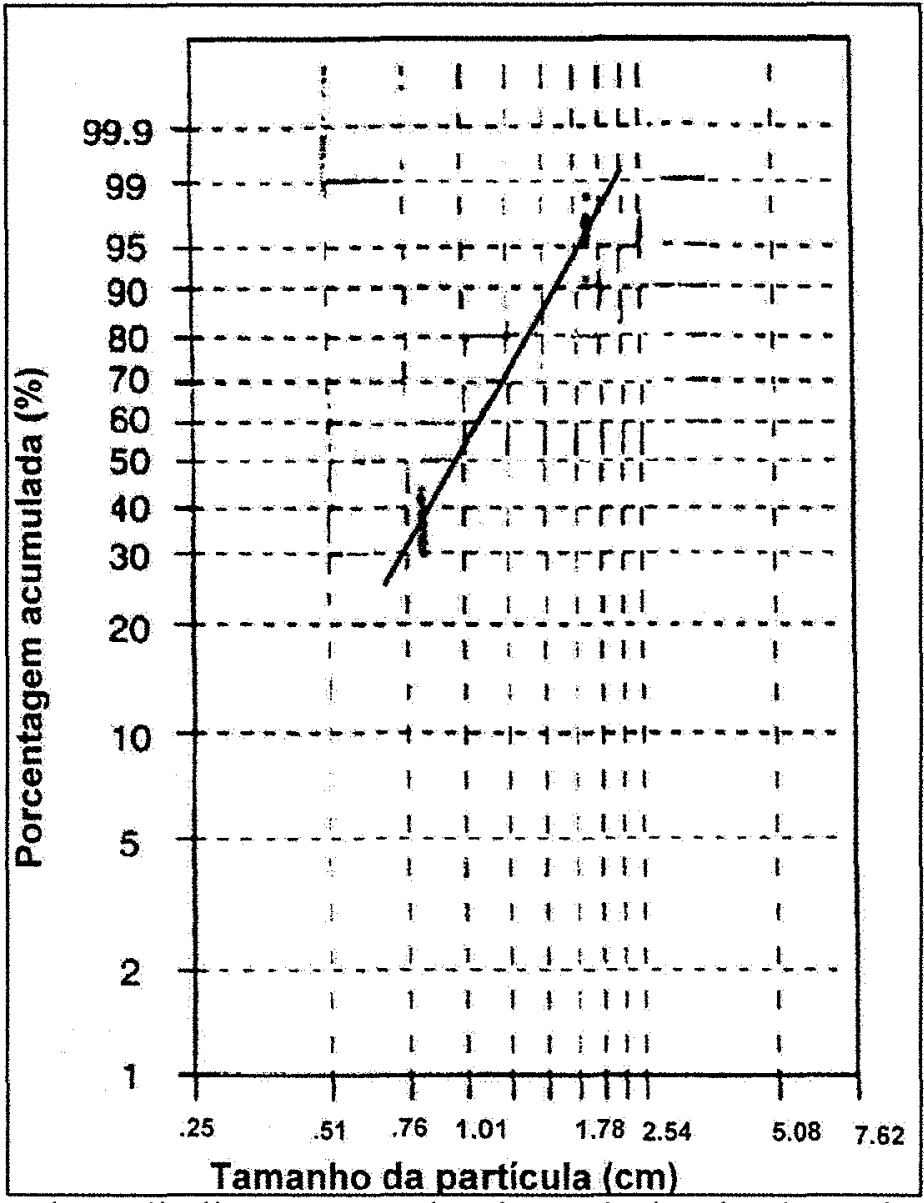

Figura 56 - Gráfico de Weibull, para tamanho de partículas de planta de milho.

A quantidade de partículas da planta até $1,0 \mathrm{~cm}$ é considerada satisfatória. De acordo com Nussio ${ }^{1}$, a porcentagem acumulada de $52 \%$ condiz com um sistema de colheita bem regulado. Esse fato refletirá em uma silagem de boa qualidade, desde que outros fatores relativos à mesma estejam também nos padrões ideais.

Ainda, o tempo de 10 horas de trabalho efetivo foi considerado insuficiente para a detecção de desgaste das lâminas de corte da máquina, não influindo no tamanho das partículas no sistema em questão.

\footnotetext{
${ }^{1}$ Nussio, L.G. (Departamento de Produção Animal - Escola Superior de Agricultura "Luiz de Queiroz", Universidade de São Paulo, Piracicaba, SP). Comunicação pessoal, 2000.
} 


\section{CONCLUSÕES}

Com base nos resultados encontrados, pôde-se concluir que a implantação das técnicas de controle estatístico de processos foi viável e adequado ao sistema de produção em questão.

$O$ estudo da qualidade do trabalho realizado na operação de escarificação mostrou-se válido, visto que ambas as áreas apresentaram diferenças consideráveis quando analisadas fosse pelos conceitos da qualidade, fosse pelos testes estatísticos tradicionais. Devido à variabilidade dos dados, foi necessária uma análise separada dos mesmos, ou seja, uma estratificação.

Os dispositivos (medidor de tamanho de torrão e penetrômetro hidráulico) utilizados mostraram-se adequados quando utilizados a campo para as tarefas designadas. Apesar da praticidade demonstrada na medição e checagem nas operações de escarificação e gradagem, novos estudos devem ser realizados com os mesmos, contrastando os valores obtidos com análises padrão para os parâmetros estudados neste trabalho.

A implantação do CEP na operação de gradagem reduziu o tamanho (diâmetro) médio dos torrões na área $\mathrm{A} 2$, apesar de não atender os padrões especificados e reduziu em quase sua totalidade o número de torrões considerados grandes, provando ser útil para o sistema.

Embora não encontrada diferença estatística (ao nível de significância de 5\%) entre as áreas, a operação de semeadura influenciou na distribuição das plantas entre as áreas, reduzindo o número de classes, quando analisada no geral. O comportamento da máquina semeadora foi satisfatório, estudando-se dados médios. Entretanto, quando analisou-se as unidades semeadoras separadamente, observou-se uma distribuição de 
plantas diferente entre todas. Os espaçamentos desejáveis $(0,2$ a $0,25 \mathrm{~m})$ aumentaram em todas as situações quando implantado o CEP, apesar de esse acréscimo não ser significativo estatisticamente.

O desenvolvimento de planta mostrou dados distintos. Em todas as avaliações semanais, a altura de plantas, para os dois tratamentos, apresentou diferenças estatísticas, indicando uma influência das operações de preparo de solo. Entretanto, para a densidade de colmos avaliada nas áreas, não houve diferença estatística entre elas, porém pôde-se inferir que houve influência do padrão de distribuição da máquina semeadora dentro das áreas.

A relação entre peso da haste e peso da planta não apresentou diferença estatística, porém a relação entre peso das folhas e peso das plantas foi significativa, tanto entre os tratamentos quanto entre as unidades semeadoras da planta, indicando influência do preparo de solo e do padrão de distribuição da máquina.

Não foi possível encontrar-se correlações entre parâmetros da massa picada original e da massa amostrada a fim de se criar ou adaptar dispositivos para medição de tamanho de partícula e avaliação de desgaste de mecanismos da máquina colhedora a campo. 


\section{REFERÊNCIAS BIBLIOGRÁFICAS}

ALMEIDA, L.G. Introdução a um processo de melhoria. Rio de Janeiro: Qualitymark, 1995. 168p.

ALMEIDA FILHO, S.L. de; FONSECA, D.M. da; GARCIA, R.; OBEID, J.A.; OLIVEIRA, J.S. e. Características agronômicas de cultivares de milho (Zea mays L.) e qualidade dos componentes e da silagem. Revista Brasileira de Zootecnia, v.28, n.1, p.7-13, 1999.

ANAZODO, U.G.N.; RAGHAVAN, G.S.V.; McKYES, E.; NORRIS, E.R. Physicomechanical properties and yield of silage corn as affected by soil compaction and tillage methods. Soil and Tillage Research, v.3, p.331-345, 1983.

ASSOCIAÇÃO BRASILEIRA DE NORMAS TÉCNICAS - ABNT. Projeto de norma 12:02.06-004: semeadora de precisão - ensaio de laboratório - método de ensaio. Rio de Janeiro, 1989. 21 p.

BALASTREIRE, L.A. Máquinas agrícolas. São Paulo: Manole, 1987. 310p.

BALSALOBRE, M.A.A.; FERNANDES, R.A.T.; SANTOS, P.M. Corte e transporte de cana-de-açúcar para consumo animal. In: SIMPÓSIO SOBRE NUTRIÇÃO DE BOVINOS, 7, Piracicaba, 1999. Alimentação suplementar: anais. Piracicaba: FEALQ, 1999. p.7-26. 
BOLLER, W.; GAMERO, C.A.; MACIEL A.J.S. Qualidade do preparo do solo com grade em função de regulagens e da utilização de discos esféricos ou cônicos. Engenharia Rural, v.6, n.2, p.1-9, 1995.

BONILLA, J.A. Qualidade total na agricultura: fundamentos e aplicações. Belo Horizonte: Centro de Estudos de Qualidade Total na Agricultura, 1994. 344p.

BONILLA, J.A. Métodos quantitativos para qualidade total na agricultura. Contagem: Líttera Maciel, 1995. 250p.

BRASSARD, M. Qualidade: ferramentas para uma melhoria continua. Rio de Janeiro: Qualitymark, 1996. 87p.

CAMPOS, V.F. TQC: gerenciamento da rotina do trabalho do dia-a-dia. Rio de Janeiro: Bloch, 1994. 276p.

CANDELON, P. Máquinas agrícolas. Madri: Multi-Prensa, 1971. 327p.

COELHO, J.L.D. Ensaio \& certificação das máquinas para a semeadura. In: MIALHE, L.G. Máquinas agrícolas: ensaios \& certificação. Piracicaba: FEALQ, 1996. cap.11, p. 551-570.

DAYNARD, T.B. Practices affecting quality and preservation of whole-plant corn silage. Canadian Journal of Plant Science, v.58, p.651-659, 1978.

DELLARETTI FILHO, O.; DRUMOND, F.B. Itens de controle e avaliação de processos. Belo Horizonte: Fundação Christiano Ottoni, 1994. 151p. 
DODSON, M.S. Avaliação da influência de indicadores de qualidade no custo operacional de um sistema de produção de milho (Zea mays L.): estudo de caso da semeadura. Jaboticabal, 1998. 80p. Monografia (Graduação) - Faculdade de Ciências Agrárias e Veterinárias, Universidade Estadual Paulista "Julio de Mesquita Filho".

FERNANDES, R.A.T. Gerenciamento da qualidade em operações agrícolas mecanizadas em um sistema de produção de cana-de-açúcar (Saccharum spp.). Piracicaba, 1997. 66p. Relatório de Residência Agronômica - Escola Superior de Agricultura "Luiz de Queiroz", Universidade de São Paulo.

FISHER, L.J.; FAIREY, N.A. The effect of planting density on the nutritive value of corn silage for lactating cows. Canadian Journal of Animal Science, v.62, p.1143$1148,1982$.

GADANHA JUNIOR, C.D.; MOLIN, J.P.; COELHO, J.L.D.; YAHN, C.H.; TOMIMORI, S.M.A.W. Máquinas e implementos agrícolas do Brasil. São Paulo: SCT; CNPq; IBICT; IPT; CIENTEC; NSI-MA, 1991. 468p.

GITLOW, H.S. Planejando a qualidade, a produtividade e a competitividade. Rio de Janeiro: Qualitymark, 1993. 182p.

HEINRICHS, J.A. Evaluating particle size of forages and TMRs using the Penn State particle size separator. University Park: Pennsylvania State University: Department of Dairy and Animal Science, 1996. 9p. (DAS 60-20).

HUNTER, R.B. Selection and evaluation procedures for whole-plant corn silage. Canadian Journal of Plant Science, v.58, p.661-678, 1978. 
IBRAHIM, B.A.; MLLER, D.E. Effect of subsoiling on yield and quality of corn and potato at two irrigation frequencies. Soil Science Society of America Journal, v.53, p.247-251, 1989.

JURAN, J.M. Juran planejando para a qualidade. São Paulo: Pioneira, 1990. 394p.

JURAN, J.M. Managerial breakthrough: the classic book on improving management performance. New York: McGraw-Hill, 1995. 451p.

KUME, H. Métodos estatísticos para melhoria da qualidade. São Paulo: Gente, 1993. $245 \mathrm{p}$.

LAMMERS, B.P.; BUCKMASTER, D.R.; HEINRICHS, A.J. A simple method for the analysis of particle sizes of forage and total mixed rations. http://wwwdas.cas.psu.edu/dcn/catforg/particle/abstract/index.html (17 Jul. 1999)

LINO, A.C.L.; PECHE FILHO, A.; STORINO, M. Análise da fragmentação de fitomassa realizada por uma roçadora em área com predominância de capimcolonião. Bragantia, v.58, n.2, p.401-407, 1999.

LOPES, M.B.; MILAN, M.; COELHO, J.L.D. Qualidade em operações agrícolas mecanizadas na cultura de cana-de-açúcar. Stab: Açúcar, Álcool e Subprodutos, v.13, n.3, p.26-30, 1995.

MAJOR, D.J.; HAMILTON, R.I. Adaptation of corn for whole-plant silage in Canada. Canadian Journal of Plant Science, v.58, p.643-650, 1978. 
McKYES, E.; NEGI, S.; DOUGLAS, E.; TAYLOR, F.; RAGHAVAN, G.S.V. The effect of machinery traffic and tillage operations on physical properties of a clay and on yield of silage corn. Journal of Agricultural Engineering Research, v.24, p.143-148, 1979.

MIRSHAWKA, V. Entrosando-se com a qualidade. São Paulo: Nobel, 1988. 307p.

MONTGOMERY, D.C. Introduction to statistical quality control. New York: John Wiley, 1996. 677p.

NICOLAS, F.; VALCESCHINI, E. Agro-alimentaire: une économie de la qualité. Paris: Economica, 1995. 287p.

NUSSIO, L.C. Avaliação de cultivares de milho (Zea mays L.) para ensilagem através da composição química e digestibilidade "in situ". Piracicaba, 1997. 58p. Dissertação (Mestrado) - Escola Superior de Agricultura "Luiz de Queiroz", Universidade de São Paulo.

NUSSIO, L.G. Cultura do milho para produção de silagem de alto valor alimentício. In: SIMPÓSIO SOBRE NUTRIÇão DE BOVINOS, 4, Piracicaba, 1991. Anais. Piracicaba: FEALQ, 1991. p.59-168.

NUSSIO, L.G. Qualidade total: a nova referência das silagens. Balde Branco, n.403, p.22-24, maio 1998.

NUSSIO, L.G.; MANZANO, R.P. Silagem de milho. In: SIMPÓSIO SOBRE NUTRIÇÃO DE BOVINOS, 7, Piracicaba, 1999. Alimentação suplementar: anais. Piracicaba: FEALQ, 1999. p.27-46. 
PASQUA, S.E. Controle da qualidade em operações agrícolas mecanizadas. In: Qualidade e produtividade na agricultura. Porto Alegre: CNPq; Fundação Roberto Marinho; Gerdau, 1999. p.53-82.

PECHE FILHO, A.; COSTA, J.A.S.; FERRETTI, G.; STORINO, M. Avaliação do grau de picagem de material orgânico: uma proposta de metodologia. In: CONGRESSO BRASILEIRO DE ENGENHARIA AGRÍCOLA, 23., Campinas, 1994. Resumos. Campinas: UNICAMP; SBEA, 1994. p.252.

PENATI, M.A. Relação de alguns parâmetros agronômicos e bromatológicos de híbridos de milho (Zea mays L.) com produção, digestibilidade e teor de matéria seca na planta. Piracicaba, 1995. 97p. Dissertação (Mestrado) - Escola Superior de Agricultura "Luiz de Queiroz", Universidade de São Paulo.

PIZARRO, E. Crescimento e desenvolvimento da planta de milho. Informe Agropecuário, v.74, n.4, p.8-9, 1978.

PIZARRO, E; ANDRADE, N.S. Momento de colheita em uma cultura de milho para silagem. Informe Agropecuário, v.74, n.4, p.9-11, 1978.

RAGHAVAN, G.S.V.; McKYES, E.; GENDRON, G.; BORGLUM, B.; LE, H.H. Effects of soil compaction on development and yield of corn (maize). Canadian Journal of Plant Science, v.58, p.435-443, 1978.

ROCHA, S.C. da (Org.) Normas para elaboração de dissertações e teses. Piracicaba: ESALQ, 1997. 94p.

SARRIÉS, G.A. Controle estatístico da qualidade para impurezas minerais em carregamentos de cana-de-açúcar. Piracicaba, 1997. 83p. Tese (Doutorado) Centro de Energia Nuclear na Agricultura, Universidade de São Paulo. 
SCHMID, A.R.; GOODRICH, R.D.; JORDAN, R.M.; MARTEN, G.C.; MEISKE, J.C. Relationships among agronomical characteristics of corn and sorghum cultivars and silage quality. Agronomy Journal, v.68, p.403-406, 1976.

SILVA, L.F.P. e. Avaliação de características agronômicas e nutricionais de híbridos de milho para silagem. Piracicaba, 1997. 98p. Dissertação (Mestrado) - Escola Superior de Agricultura "Luiz de Queiroz", Universidade de São Paulo.

SILVA, M.R.; PECHE FILHO, A.; STORINO, M.; LINO, A.C.L.; SPINACE, E.M. Avaliação da performance da plantadora de batatas UN 3200 Kverneland. In: CONGRESSO BRASILEIRO DE ENGENHARIA AGRÍCOLA, 25., Bauru, 1996. Resumos. Bauru: UNESP; SBEA; ALIA, 1996. p.555.

SMITH, H.P.; WILKES, L.H. Maquinaria y equipo agrícola. Barcelona: Ed. Omega, 1979. 520p.

TOLEDO, J.C. de. Gestão da qualidade na agroindústria. In: BATALHA, M.O. (Ed.) Gestão agroindustrial. São Paulo: Atlas, 1997. cap. 8, p.437-487.

WAGGER, M.G.; CASSEL, D.K. Corn yield and water efficiency as affected by tillage and irrigation. Soil Science Society of America Journal, v.57, p.229-234, 1993.

WERKEMA, M.C.C. Avaliação da qualidade de medidas. Belo Horizonte: Fundação Christiano Ottoni; Escola de Engenharia da UFMG, 1996. 98p. (Série Ferramentas da Qualidade) 
WERKEMA, M.C.C.; AGUIAR, S. Análise de regressão: como entender o relacionamento entre as variáveis de um processo. Belo Horizonte: Fundação Christiano Ottoni, Escola de Engenharia da UFMG, 1996. 311p. (Série Ferramentas da Qualidade)

WHITE, R.P. Cultural practices affecting maturity and yield of corn (Zea mays) for whole-plant silage in short-season areas. Canadian Journal of Plant Science, v.58, p.628-642, 1978 .

VAN SOEST, P.J.; MERTENS, D.R.; DEINUM, B. Preharvest factors influencing quality of conserved forage. Journal of Animal Science, v.47, n.3, p.712-720, 1978.

VIEIRA, S. Estatística para a qualidade: como avaliar com precisão a qualidade em produtos e serviços. Rio de Janeiro: Campus, 1999. 198p.

VILELA, H. Silagem. Informe Agropecuário, v.108, n.9, p.17-27, 1983. 